\title{
Review Article \\ Single-Stranded DNA Aptamers against Pathogens and Toxins: Identification and Biosensing Applications
}

\author{
Ka Lok Hong and Letha J. Sooter \\ Department of Basic Pharmaceutical Sciences, 1 Medical Center Drive, P.O. Box 9530, Morgantown, WV 20506, USA \\ Correspondence should be addressed to Letha J. Sooter; lsooter@hsc.wvu.edu
}

Received 1 March 2015; Accepted 27 May 2015

Academic Editor: Maria C. De Rosa

Copyright (c) 2015 K. L. Hong and L. J. Sooter. This is an open access article distributed under the Creative Commons Attribution License, which permits unrestricted use, distribution, and reproduction in any medium, provided the original work is properly cited.

\begin{abstract}
Molecular recognition elements (MREs) can be short sequences of single-stranded DNA, RNA, small peptides, or antibody fragments. They can bind to user-defined targets with high affinity and specificity. There has been an increasing interest in the identification and application of nucleic acid molecular recognition elements, commonly known as aptamers, since they were first described in 1990 by the Gold and Szostak laboratories. A large number of target specific nucleic acids MREs and their applications are currently in the literature. This review first describes the general methodologies used in identifying single-stranded DNA (ssDNA) aptamers. It then summarizes advancements in the identification and biosensing application of ssDNA aptamers specific for bacteria, viruses, their associated molecules, and selected chemical toxins. Lastly, an overview of the basic principles of ssDNA aptamer-based biosensors is discussed.
\end{abstract}

\section{Introduction}

Target detection in diagnostics and sensors relies on successful molecular recognitions. Traditionally, antibodies have been used in biosening applications due to their target specificities and affinities. However, the inherent properties of proteins give rise to many shortcomings of antibodies. In 1990, the Gold Laboratory first described a process, termed Systematic Evolution of Ligands by Exponential Enrichment (SELEX) [1], which identifies one or few molecular recognition elements (MREs) with high affinity and specificity toward their intended targets. MREs can be short sequences of single-stranded DNA, RNA, small peptides, or antibody fragments. All types of MREs are capable of binding to user-defined targets with high affinity and specificity, and these targets include proteins, small molecules, viruses, whole bacteria cells, and mammalian cells [2].

In order to identify nucleic acid MREs, the SELEX process generally begins from a very large random library consisting of $10^{13}$ to $10^{15}$ different molecules. An individual nucleic acid MRE is composed of two constant regions for primer attachment during polymerase chain reaction (PCR) amplification flanked by $20-80$ bases of random region [3].
The target of interest is first incubated with the library under specific ionic and temperature conditions. Library molecules that bind to the target are retained and amplified by PCR, while nonbinding library molecules are discarded. Negative or counter selections are often performed to increase the specificity of the library or direct the enrichment process away from binding to negative targets. Negative targets are often chosen for their structural similarities or the likelihood to coexist in the native environment with the target of interest. In this case, library molecules that bind to negative targets are discarded and those that do not bind are retained and amplified and thus completing one round of in vitro selection (Figure 1). It is expected that the library is enriched enough after approximately 12 rounds of SELEX. One or few nucleic acid MREs with high specificity and affinity toward their targets can be identified.

Both DNA and RNA MREs can conform into three dimensional structures, which include stem-loop, bulges, and/or hairpin regions and give rise to binding pockets for their respective targets [4]. There are reports suggesting that RNA MREs generally have a higher affinity for their target than their DNA counterparts [5]. However, unmodified RNA molecules are more susceptible to nuclease degradations than 


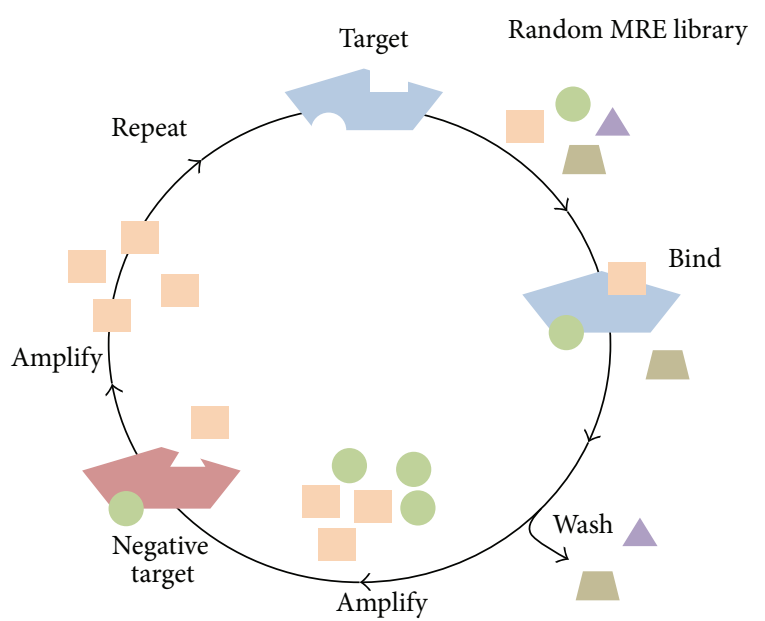

FIgURE 1: Illustration of the SELEX process. A random library consisting of up to $10^{15}$ single-stranded nucleic acids molecules are incubated with the target of interest. Those that bound to the target are retrieved and amplified by polymerase case reaction. It is then followed by incubation with negative targets. Those that do not bind to negative targets are retained, amplified, and subjected to further rounds of in vitro selection.

DNA. Modification on the $2^{\prime}$ hydroxyl of RNA molecules can increase their stabilities but may have negative impact on their binding affinities [6,7]. It is also more difficult to amplify RNA MREs during selection, as reverse transcription to DNA must be performed prior to PCR. For these given reasons, there is a bigger hurdle to successfully identify and apply RNA MREs in molecular detection, and thus this review has chosen to focus on the discussion of ssDNA MREs in biosening applications.

Single-stranded DNA MREs have high affinity and specificity toward their targets that is comparable to antibodies. In addition, ssDNA MREs have several advantages over antibodies. Firstly, ssDNA MREs are more thermostable and can be reversibly denatured. This reusability is particularly desired for molecular sensing applications. Secondly, ssDNA MREs can be identified for targets that are nonimmunogenic or toxic to cells, as the SELEX process can be performed completely in vitro and independent of living systems. Lastly, identified ssDNA MREs with known sequences can be chemically synthesized at low cost and without batch to batch variations [8]. Different modifications such as thiol or amino functional groups can also be easily incorporated onto the $3^{\prime}$ and/or $5^{\prime}$ ends of oligonucleotides during synthesis and utilized for immobilization on solid platforms. Similarly, labeling molecules such as biotin or FITC can also be covalently attached and serve as reporters in sensing applications. The attractive features of ssDNA MREs allow researchers to investigate the translational application of biosensors. This review focuses on the recent advancements in the identification and biosensing application of ssDNA MREs specific for bacteria, viruses, their associated biomolecules, virulence factors, and selected biological and chemical toxins. Detection of these targets has been shown to be important in medical diagnosis, food safety, and environmental monitoring. Additionally, major principles in MRE based biosensors are briefly discussed.

\section{In Vitro Selection of ssDNA Molecular Recognition Elements}

2.1. General Methodology of SELEX. The general process of in vitro selection of ssDNA MREs starts from design and chemical synthesis of ssDNA library. ssDNA library consists of two predetermined constant regions for primer attachment during PCR amplification flanking a random region. This random region gives raise to the diversity of the library, which can be designated by $4^{n}$, where $n$ is the number of bases in the random region. Longer random regions not only may result in increased library diversity, but also may risk inhibition of PCR amplification due to secondary structure formation. Therefore, the overall libraries lengths are usually designed to be less than 150 bases in total length, including a random region of 20 to 80 bases, and are chemically synthesized using phosphoramidite chemistry [3].

The SELEX process begins by incubating up to $10^{15}$ different ssDNA molecules with the target of interest. One of the key steps in the SELEX process is the separation of bound MREs from unbound MREs. The separation process is often achieved by target immobilization. Immobilization options include nitrocellulose membranes that can be used to adsorb protein targets [9] and histidine tags on recombinant proteins that can be with a metal affinity chromatography column [10]. However, ssDNA molecules may nonspecifically adsorb to immobilizing substrates. A round of negative selection is typically performed prior to the start of the first round of positive selection to reduce the nonspecific adsorption between the library and immobilizing substrates. Magnetic beads have also been used to immobilize a wide range of targets [11-14]. The terminal primary amine or a surface lysine on a protein can be used to conjugate onto carboxylic acid coated magnetic beads via EDC/NHS reactions. Small molecule targets or target analogs with available functional groups can also be biotinylated and immobilized on streptavidin coated magnetic beads based on the strong affinity between biotin and streptavidin [14, 15]. Magnets can then be used for the separation of bound and unbound molecules. However, this technique runs the risk of selecting MREs bound to magnetic beads and/or streptavidin. Sooter and coworkers successfully showed that competitive elution with free target can effectively isolate ssDNA MREs specific for the target of interest and not for the immobilizing substrates or analog molecules [14-16].

Amplification of the ssDNA library is also crucial to the success of the in vitro selection process. PCR conditions have to be determined and optimized before the selection process. After the retrieval of target bound ssDNA molecules for each round of selection, a small-scale PCR can be carried out to determine the cycles of PCR needed to successfully amplify the library. Large-scale PCR can subsequently be performed based on the determined number of reaction, 
and thus decreasing the chance of overamplification and the generation of undesired PCR amplicons.

It is necessary to obtain ssDNA from double-stranded PCR product prior to the subsequent rounds of selection. Several techniques have been shown to effectively isolate the single-stranded binding element from double-stranded DNA, such as asymmetric PCR, biotin-streptavidin separation, lambda exonuclease digestions, and size separation on denaturing urea polyacrylamide gel electrophoresis. Asymmetric PCR uses a different ratio of forward and reverse primer in the reaction mixture to generate both dsDNA and ssDNA allowing the two types of DNA molecules to be visualized and separated using agarose gel electrophoresis. The ssDNA is then excised and purified [17]. Biotin-streptavidin separation uses a biotin-tagged primer in the PCR amplification process to generate biotinylated dsDNA. The dsDNA can then be captured by streptavidin coated beads. The unbound strand of DNA can be retrieved using sodium hydroxide [18]. Lambda exonuclease can selectively digest a phosphorylated strand of the dsDNA in $5^{\prime}$ to $3^{\prime}$ direction. PCR reactions carried out with a phosphorylated reverse primer can be selectively digested by lambda exonuclease, leaving only the forward strand [19]. Modified primers can be used to create size differences between the forward and reverse strands and be detected by using urea denaturing PAGE, and subsequently ssDNA can be excised and purified [20].

2.2. Examples of Modified SELEX. The general process of SELEX has been modified over the past two decades. These modifications mostly focus on increasing the efficiency in separating bound and unbound MREs, increasing specificity of the selected MREs, eliminating the need for immobilizing target molecules, selecting against live whole cells, and decreasing the overall labor intensiveness of the SELEX process. Selected modified SELEX methods pertinent to this review are briefly discussed.

Negative or counter selection is incorporated into the normal SELEX process by introducing negative targets that have structural similarity to the target of interest or are likely to coexist in the target's environment. This modification is to increase the overall specificity of the library during selection and thus identify MREs that are highly specific to the target. Williams and coworkers identified ssDNA MRE target for herbicide, atrazine, with 2.1-fold higher binding affinity to atrazine than to a closely related herbicide, simazine, by introducing multiple negative selection rounds and increasing stringency during the selection [14]. This stringent negative selection scheme was utilized to obtain two other ssDNA MREs that bind to their respective targets with high affinity and specificity $[15,16]$.

Capillary electrophoresis can separate molecules based upon their charges. Target bound and unbound DNA molecules migrate at different rates due to differences in their overall charges, and therefore different species can be separated and collected at different time points. Mendonsa and Bowser were the first to use capillary electrophoresis to identify a ssDNA MRE specific for human IgE. Due to its high efficiency in separating different molecules, MREs can generally be identified in 4 to 6 rounds of capillary electrophoresis based SELEX (CE-SELEX) [21]. CE-SELEX can also select MREs bound to free targets in solution and without the need of immobilization. A variant of CE-SELEX utilizes nonequilibrium capillary electrophoresis of equilibrium mixtures (NECEEM) to achieve separation (NonSELEX) has also been developed. In Non-SELEX, repetitive rounds of selection are performed without PCR amplification. Berezovski and coworkers were the first to use NonSELEX to identify a high affinity MRE $\left(K_{d}: 0.3 \mathrm{nM}\right)$ specific for hRas protein [22].

Park and coworkers developed an immobilization-free SELEX method based on $\pi-\pi$ stacking interaction between DNA and graphene oxide (GO-SELEX). In GO-SELEX, ssDNA library is adsorbed on graphene oxide and then incubated with the target. In the presence of the target, a portion of the ssDNA library is released from graphene oxide and bind preferentially to the target, while unbound ssDNA remains adsorbed and can be separated by centrifugation [23]. This method was used to isolate ssDNA MREs specific for bovine viral diarrhea virus type 1 [24]. A highthroughput modification of GO-SELEX was also developed by Nguyen and coworkers to identify flexible ssDNA MREs that are specific for multiple pesticides with affinities in the nanomolar range [25]. Nutiu and Li developed a different target immobilization-free SELEX method using a ssDNA library containing a 15-base constant region, sandwiched by two random regions, and finally encompassed by two constant primer hybridization regions at both $3^{\prime}$ and $5^{\prime}$ ends [26]. The 15 bases constant region can hybridize with biotinylated complementary strand and can be captured by streptavidin coated beads. Binding of the ssDNA library to target molecules induces conformational changes, thus releasing the binding-strand from the complementary strand. This method has been adapted to screen for ssDNA MREs specific for multiple pesticides $[27,28]$.

FluMag-SELEX was developed by Stoltenburg and coworkers by immobilizing targets on magnetic beads, using fluorescently labeled forward primer during PCR amplification [29]. Magnetic separation of bound and unbound MREs is performed similarly to traditional magnetic bead based SELEX. However, the overall binding capacity of the library can be monitored precisely with the presence of fluorescence tag. The selection process can then be terminated when the overall library binding affinity toward the target reaches a plateau. A similar technique has been incorporated in single microbead SELEX described by Tok and Fischer. In their work, only 2 cycles of SELEX were performed to identify multiple ssDNA MREs specific for botulinum neurotoxin with low micro- to nanomolar $K_{d}$ values [30]. The usage of fluorescence tag in the library is further investigated by Lauridsen and coworkers by performing a one-step selection against alpha-bungarotoxin [31].

Microfluidic chips are also being investigated to facilitate the SELEX process (M-SELEX). Microfluidic chips are capable of manipulating a very small amount of immobilized target on magnetic beads, thus achieving a more efficient separation of bound MREs [32]. Qian and coworkers were able to identify ssDNA MREs specific for Botulinum neurotoxin 
type A with low nanomolar binding affinity after only one round of selection $[32,33]$. Recently, MREs with nanomolar binding affinity specific for whole influenza A/H1N1 virus were selected using M-SELEX [34].

Complex targets such as live mammalian and bacteria whole cells have become popular targets for selection. These types of selection are called cell-SELEX or whole cellSELEX. Early works mostly focused on identifying MREs specific for tumor cells [35-38]. The general methodology of cell-SELEX is very similar to traditional SELEX, but fluorescence-activated cell sorting (FACS) can be utilized to achieve a very high level of separation of MRE bound and unbound cell targets. Multiple pathogenic bacteria genera, such as Salmonella, Pseudomonas, Staphylococcus, Listeria, and Escherichia have been chosen as a selection target. The selection and biosening application of ssDNA MREs targeting bacteria, viruses, and associated biomolecules are discussed in the following section.

2.3. Single-Stranded DNA MREs Targeting Bacteria. Singlestranded DNA MREs targeting bacteria can be classified into two general categories, (1) targeting whole cells with known or unknown molecular targets and (2) targeting predefined bacteria cell surface targets or bacteria spores (Table 1).

Multiple virulent strains of the gram-negative bacteria, Escherichia coli, have been chosen as targets for the selection of specific ssDNA MREs due to their enterotoxigenic effects and the potential of contaminating food and water [39]. Peng et al. enriched ssDNA MRE library specific for $E$. coli K88 whole bacteria [40]. They also developed a sandwich detection system, in which biotinylated antibodies targeting the K88 strain were immobilized on magnetic beads as the capturing element and the $5^{\prime}$ FITC labeled ssDNA library from round 13 selection served as the reporter in a fluorescent assay. A lower limit of detection (LOD) of $1100 \mathrm{CFU} / \mathrm{mL}$ was achieved in pure culture. Artificial contaminated fecal samples were also tested with a LOD of $2200 \mathrm{CFU}$ per gram. However, no individual ssDNA MRE was able to achieve the same degree of binding affinity as the whole library and ssDNA MRE with high affinity and specificity against K88 fimbriae protein was selected after 11 rounds [41]. A fluorescence binding assay was used to obtain the affinity of the selected MRE candidates. The reported equilibrium dissociation constant $\left(K_{d}\right)$ for the best candidate MRE was $25 \pm 4 \mathrm{nM}$. Kim et al. performed 10 rounds of selection against a fecal strain of $E$. coli along with multiple negative selections against other species of bacteria. They identified four candidate sequences with high affinity for the target strain. All four candidates were highly selective against negative target bacteria. However, they all showed cross-binding activity with other strains of $E$. coli. This suggested that the selected candidates potentially bound to common antigens expressed in multiple strains of E. coli [42]. Savory et al. identified ssDNA MRE with high specificity and affinity $\left(K_{d}=110 \mathrm{nM}\right)$ for an uropathogenic strain of E. coli. Quantitative PCR was used to monitor the SELEX process in order to minimize the number of rounds of SELEX required. After 5 rounds of SELEX, a selected ssDNA MRE containing a guaninequadruplex sequence motif showed low cross-binding activities toward other strains of E. coli [43]. In addition to selecting whole E. coli bacteria as targets, outer membrane protein from E. coli 8739 (Crook's strain) and lipopolysaccharide from O111:B4 strains were also chosen as targets for selection. A fluorescence resonance energy transfer (FRET) assay was developed to detect E. coli 8379 with a LOD of $30 \mathrm{CFU} / \mathrm{mL}$ [44]. The ssDNA MRE targeting lipopolysaccharide showed antibacterial effects on both O111:B4 and K12 strains [45]. However, $K_{d}$ values were not reported in either study.

Several ssDNA MREs have been selected against species of foodborne bacteria including Salmonella, Listeria, and Vibrio. Dwivedi et al. identified ssDNA MRE specific for whole cell Salmonella enterica serovar Typhimurium with a reported $K_{d}$ of $1.73 \pm 0.54 \mu \mathrm{M}$ after eight rounds of selection [46]. Two rounds of negative selection against a mixture of nontarget bacteria were also performed to enhance the selectivity of the library. A detection application was developed using immobilized biotinylated MREs on streptavidin coated magnetic beads as the capturing elements and was coupled with quantitative PCR. The reported LOD of this assay was between 100 to $1000 \mathrm{CFU}$ in a $290 \mu \mathrm{L}$ sample volume. Duan et al. performed a similar selection on the same organism with nine rounds of target selection and two rounds of negative selection against mixtures of nontarget bacteria [47]. The best candidate ssDNA MRE had a $K_{d}$ value of $6.33 \pm 0.58 \mathrm{nM}$ and high specificity based upon flow cytometry analysis. A fluorescence bioassay achieved a LOD of $25 \mathrm{CFU} / \mathrm{mL}$. Another similar study performed by Moon et al. showed relatively high affinities and specificities of selected candidate sequences after ten rounds of target and six rounds of negative selections. However, no $K_{d}$ values were reported in the study [48]. Outer membrane proteins of Salmonella enterica serovar Typhimurium were chosen as selection target by Joshi et al. In that study seven rounds of selection were performed with three rounds of negative selection against E. coli outer membrane proteins and lipopolysaccharides. A magnetic bead based quantitative real-time PCR assay was developed using immobilized ssDNA MRE as the capturing element. Food and environmental samples were tested to demonstrate the translational usage of the assay. A LOD of less than $10 \mathrm{CFU}$ per gram of artificially contaminated bovine feces was reported. Additionally, 10 to 100 of CFU were detected in $9 \mathrm{~mL}$ of artificially contaminated whole carcass chicken rinse sample solution in a pull-down assay [49]. Two recent studies identified ssDNA MREs specific for two serovars of Salmonella, Typhimurium, and Enteritidis $[50,51]$. Park et al. truncated out the random region (29 to 30 mer) of selected candidates and identified three ssDNA MREs with $K_{d}$ values in micromolar range toward their respective serovars after ten rounds of mixed target and counter target selection. Poly-D-lysine was conjugated to the selected MREs and achieved an approximately 20- to 100-fold enhancement in their binding affinities [51]. Kolovskaya et al. also performed a similar selection on the two serovars of Salmonella [50]. After twelve rounds of selection, two ssDNA MREs with $K_{d}$ values range in nanomolar were identified (Enteritidis: $K_{d}=7 \mathrm{nM}$; Typhimurium: $K_{d}=25 \mathrm{nM}$ ). 
TABLE 1: Summary table of ssDNA MREs targeting bacteria and bacteria structural components.

\begin{tabular}{|c|c|c|c|c|c|}
\hline Target & SELEX method & $K_{d}$ & Detection method & LOD & Reference \\
\hline E. coli $\mathrm{K} 88$ & Cell-SELEX & $15 \pm 4 \mathrm{nM}$ & Fluorescence & $1100 \mathrm{CFU} / \mathrm{mL}$ & {$[40]$} \\
\hline E. coli & Cell-SELEX & 12.4 to $25.2 \mathrm{nM}$ & - & - & {$[42]$} \\
\hline E. coli NSM59 & Cell-SELEX & $110 \mathrm{nM}$ & - & - & {$[43]$} \\
\hline E. coli K88 fimbriae protein & Plate immobilized & $25 \pm 4 \mathrm{nM}$ & - & - & [41] \\
\hline $\begin{array}{l}\text { E. coli } 8739 \text { outer membrane } \\
\text { protein }\end{array}$ & Magnetic beads & - & FRET & $30 \mathrm{CFU} / \mathrm{mL}$ & {$[44]$} \\
\hline $\begin{array}{l}\text { E. coli O111:B4 } \\
\text { Lipopolysaccharide }\end{array}$ & Magnetic beads & - & - & - & {$[45]$} \\
\hline Salmonella Typhimurium & Cell-SELEX & $1.73 \pm 0.54 \mu \mathrm{M}$ & Magnetic capture-qPCR & $100-1000 \mathrm{CFU}$ & {$[46]$} \\
\hline Salmonella Typhimurium & Cell-SELEX & $6.33 \pm 0.58 \mathrm{nM}$ & Fluorescence & $25 \mathrm{CFU} / \mathrm{mL}$ & {$[47]$} \\
\hline Salmonella Typhimurium & Cell-SELEX & - & - & - & {$[48]$} \\
\hline $\begin{array}{l}\text { Salmonella Typhimurium } \\
\text { outer membrane protein }\end{array}$ & $\begin{array}{l}\text { Nitrocellulose } \\
\text { membrane }\end{array}$ & - & $\begin{array}{l}\text { Magnetic capture-qPCR } \\
\text { (spike and recovery) }\end{array}$ & $<10 \mathrm{CFU} / \mathrm{g}$ & {$[49]$} \\
\hline $\begin{array}{l}\text { Salmonellae } \\
\text { Typhimurium/enteritidis }\end{array}$ & Cell-SELEX & $\begin{array}{l}\text { Nanomolar to } \\
\text { micromolar range }\end{array}$ & - & - & {$[51]$} \\
\hline $\begin{array}{l}\text { Salmonellae } \\
\text { enteritidis/Typhimurium }\end{array}$ & Cell-SELEX & $7 \mathrm{nM}, 25 \mathrm{nM}$ & - & - & {$[50]$} \\
\hline Salmonella Paratyphi A & Cell-SELEX & $47 \pm 3 \mathrm{nM}$ & Chemiluminescence & $1000 \mathrm{CFU} / \mathrm{mL}$ & {$[52]$} \\
\hline Salmonella O8 & Cell-SELEX & $32.04 \mathrm{nM}$ & - & - & [53] \\
\hline Vibrio alginolyticus & Cell-SELEX & $27.5 \pm 9.2 \mathrm{nM}$ & PCR & $100 \mathrm{CFU} / \mathrm{mL}$ & [56] \\
\hline Vibrio parahaemolyticus & Cell-SELEX & $16.88 \pm 1.92 \mathrm{nM}$ & - & - & {$[55]$} \\
\hline Listeria monocytogenes & Cell-SELEX & Midnanomolar range & - & - & {$[57]$} \\
\hline Listeria monocytogenes & Cell-SELEX & $35.7 \pm 8.02 \mu \mathrm{M}$ & Magnetic capture-qPCR & $<60 \mathrm{CFU} / 500 \mu \mathrm{L}$ & {$[58]$} \\
\hline Listeria monocytogenes & Cell-SELEX & $60.01 \mathrm{nM}$ & Fluorescence & - & [60] \\
\hline Listeria monocytogenes & Cell-SELEX & $48.74 \pm 3.11 \mathrm{nM}$ & Fluorescence & $75 \mathrm{CFU} / \mathrm{mL}$ & [59] \\
\hline $\begin{array}{l}\text { Listeria monocytogenes } \\
\text { Internalin A }\end{array}$ & Filter plate & - & Fiber optic & $1000 \mathrm{CFU} / \mathrm{mL}$ & {$[62]$} \\
\hline Shigella dysenteriae & Cell-SELEX & $23.47 \pm 2.48 \mathrm{nM}$ & Fluorescence & $50 \mathrm{CFU} / \mathrm{mL}$ & {$[64]$} \\
\hline Streptococcus mutans & Cell-SELEX & $33 \mathrm{nM}$ & $\begin{array}{l}\text { Colorimetric } \\
\text { (flow-through) }\end{array}$ & $10^{5}-10^{8} \mathrm{CFU} / \mathrm{mL}$ & {$[70]$} \\
\hline Streptococcus pyogenes & Cell-SELEX & $9,10 \mathrm{nM}$ & - & - & {$[72]$} \\
\hline Staphylococcus aureus & Cell-SELEX & $35,129 \mathrm{nM}$ & Optical light scattering & $1 \mathrm{CFU} / \mathrm{mL}$ & [75] \\
\hline Staphylococcus aureus & Cell-SELEX & Nanomolar range & - & - & [74] \\
\hline Proteus mirabilis & Cell-SELEX & $7.7 \mathrm{nM}, 4.1 \mathrm{nM}$ & - & - & {$[69]$} \\
\hline Pseudomonas aeruginosa & Cell-SELEX & Low nanomolar range & Fluorescence & - & {$[78]$} \\
\hline Mycobacterium tuberculosis & Cell-SELEX & $K_{a} 10^{5}-10^{6} \mathrm{M}$ & - & - & [80] \\
\hline $\begin{array}{l}\text { Francisella tularensis } \\
\text { subspecies (subsp.) japonica } \\
\text { bacterial antigen }\end{array}$ & Cell-SELEX & - & ALISA & 1700 bacteria $/ \mathrm{mL}$ & {$[86]$} \\
\hline $\begin{array}{l}\text { Bacillus anthracis } \\
\text { spores/anthrose sugar }\end{array}$ & Magnetic beads & - & & 30,000 spores/mL & {$[84]$} \\
\hline Bacillus anthracis spores & Magnetic beads & - & $\begin{array}{l}\text { Magnetic bead- } \\
\text { electrochemiluminescence }\end{array}$ & $10.6 \times 10^{6}$ spores & {$[82]$} \\
\hline Bacillus thuringiensis spores & Magnetic beads & - & Fluorescence & $1000 \mathrm{CFU} / \mathrm{mL}$ & [83] \\
\hline Campylobacter jejuni & Cell-SELEX & $292.8 \pm 53.1 \mathrm{nM}$ & - & - & [68] \\
\hline $\begin{array}{l}\text { Campylobacter jejuni } \\
\text { (surface protein) }\end{array}$ & Magnetic beads & - & $\begin{array}{l}\text { Fluorescence (magnetic } \\
\text { bead/quantum dot) }\end{array}$ & $\begin{array}{l}10-250 \mathrm{CFU} \text { in } \\
\text { food matrix, } \\
2.5 \mathrm{CFU} \text { in buffer }\end{array}$ & [66] \\
\hline $\begin{array}{l}\text { Campylobacter jejuni } \\
\text { (killed) }\end{array}$ & CE-SELEX & - & Capillary electrophoresis & $6.4 \times 10^{6}$ cells $/ \mathrm{mL}$ & [67] \\
\hline Peptidoglycan & Filter & $\begin{array}{l}0.415 \pm 0.047 \mu \mathrm{M} / 1.261 \\
\pm 0.280 \mu \mathrm{M}\end{array}$ & - & - & {$[88]$} \\
\hline $\begin{array}{l}\text { Lipopolysaccharide } \\
\text { (endotoxin) }\end{array}$ & $\begin{array}{l}\text { NECEEM } \\
\text { non-SELEX }\end{array}$ & $\begin{array}{l}\text { Low to high nanomolar } \\
\text { range }\end{array}$ & Electrochemical & $0.01-1 \mathrm{ng} / \mathrm{mL}$ & [91] \\
\hline
\end{tabular}


Both selected MREs were able to demonstrate a bacteriostatic effect in their respective bacterial cultures. An antibioticresistant serovar of Salmonella enterica, Paratyphi A, was chosen as target by Yang et al. A total of thirteen positive rounds and four negative rounds of selection were performed to identify an MRE with high affinity $\left(K_{d}=47 \pm 3 \mathrm{nM}\right)$ and specificity toward Paratyphi A. LOD of $1000 \mathrm{CFU} / \mathrm{mL}$ was achieved using chemiluminescence assay based on selfassembled single-walled carbon nanotubes and DNAzymeslabeled MRE as detection elements [52]. MRE with high specificity toward Salmonella $\mathrm{O} 8$ was identified by Liu et al. after eleven rounds of positive and two rounds of negative selection. The selected MRE had a reported $K_{d}$ of $32.04 \mathrm{nM}$. A preliminary fluorescent in situ labeling assay was developed with the MRE. However, no LOD was reported [53].

Consumption of uncooked or undercooked seafood contaminated by Vibrio bacteria can lead to food poisoning [54]. Two different species, Vibrio parahaemolyticus and Vibrio alginolyticus were chosen as selection targets. Nine rounds of cell-SELEX using flow cytometry were carried out to identify ssDNA MRE with high affinity and specificity for Vibrio parahaemolyticus $\left(K_{d}=16.88 \pm 1.92 \mathrm{nM}\right)[55,56]$. Tang et al. performed 15 rounds of cell-SELEX on inactivated Vibrio alginolyticus. Negative selection was performed every third positive target round to improve the library specificity. The study did not characterize affinities and specificities of candidate ssDNA MREs from the last round of selection. Instead, the whole library was characterized to have a $K_{d}$ value of $27.5 \pm 9.2 \mathrm{nM}$ and was highly specific toward the target. The enriched library was able to detect $100 \mathrm{CFU} / \mathrm{mL}$ of the bacteria based on a PCR amplification assay [56].

Listeria monocytogenes is a foodborne gram-positive bacterium that can cause serious illnesses and even death. FDA and European Union both have zero tolerance of $L$. monocytogenes in ready-to-eat food products. Suh et al. conducted two studies to identify ssDNA MREs specific for L. monocytogenes $[57,58]$. In their earlier study, MRE with a micromolar $K_{d}$ value was identified after six rounds of positive and two rounds of negative selections. The MRE showed low cross-binding to negative target bacteria but had similar binding affinity for other members of the Listeria genus. A magnetic bead based capture assay coupled with quantitative PCR was developed. The assay was able to detect less than $60 \mathrm{CFU}$ in $500 \mu \mathrm{L}$ of binding buffer containing a mixture of non-Listeria bacteria [58]. In their later study, the affinities of selected candidate MREs were improved with reported values of $K_{d}$ in the nanomolar range and were specific for the target bacteria at different growth phases [57]. Duan et al. performed similar whole cell in vitro selection on L. monocytogenes. The selected MRE had high affinity $\left(K_{d}=48.74 \pm 3.11 \mathrm{nM}\right)$ and was highly specific toward the target. A fluorescent cross-binding assay showed significantly lower binding activities toward negative bacteria targets and other bacteria species in the Listeria genus. A sandwich fluorescent bioassay was developed and demonstrated a LOD of $75 \mathrm{CFU} / \mathrm{mL}$ [59]. Most recently, Liu et al. performed eight rounds of selection to identify ssDNA MREs specific for $L$. monocytogenes. The best candidate MRE reported to have a $K_{d}$ value of $60.01 \mathrm{nM}$ and had high specificity. A fluorescent based detection assay was developed to enable the observation of binding between the MRE and target bacteria using fluorescent microscope, but the LOD was not reported [60].

Ohk et al. selected ssDNA MRE specific for internalin A of L. monocytogenes. Internalin $\mathrm{A}$ is a major invasion protein expressed on the cell surface of L. monocytogenes [61]. A highly specific sandwich style fiber optic biosensor was developed by using the selected MRE and antibody. A reported LOD of $1000 \mathrm{CFU} / \mathrm{mL}$ was achieved. The sensor also successfully detected the bacteria in artificially contaminated ready-to-eat meat products. However, affinity data was not reported in the study [62].

Shigella dysenteriae is a gram-negative bacterium that causes severe epidemic diarrhea in many countries [63]. Duan et al. used cell-SELEX methodology to identify ssDNA MRE specific for $S$. dysenteriae [47, 55, 59, 64]. The best candidate MRE had a reported $K_{d}$ value of $23.47 \pm 2.48 \mathrm{nM}$ and low cross-binding activities toward negative bacteria targets. A fluorescent based detection assay demonstrated a LOD of $50 \mathrm{CFU} / \mathrm{mL}$ [64].

Campylobacter jejuni is a highly infectious gram-negative bacterium that is one of the leading causes of acute diarrheal sickness worldwide [65]. Bruno et al. performed an in vitro selection by extracting surface proteins of $C$. jejuni and immobilizing them on magnetic beads. No values of $K_{d}$ were reported in the study. However, a fluorescent assay based on magnetic beads and quantum dot was developed to detect the bacteria in different food matrices. The assay showed low cross-binding activities with other species of bacteria but was not able to distinguish between bacteria in the Campylobacter genus. The reported LODs were $2.5 \mathrm{CFU}$ and 10 to $250 \mathrm{CFU}$ in buffer solution and in different food matrices, respectively [66]. CE-SELEX was employed by Stratis-Cullum et al. to identify MREs specific for C. jejuni. Killed bacteria were used as target in their study. A qualitative capillary electrophoresis immunoassay was developed with a LOD of $6.3 \times 10^{6}$ cells $/ \mathrm{mL}$ [67]. Dwivedi et al. performed cell-SELEX on live C. jejuni. A total of ten positive rounds and two negative rounds were carried out to identify ssDNA MREs with high affinity and specificity toward the target bacteria $\left(K_{d}=292.8 \pm 53.1 \mathrm{nM}\right)$ [68].

Bacteria that are associated with common infectious diseases, such as Streptococcus, Staphylococcus, and Pseudomonas, are also popular targets for in vitro selection. Identification of MREs targeting infectious bacteria could be potentially used to facilitate diagnosis and thus decreasing the time between culture collections to specific antibiotic treatment.

Savory et al. performed cell-SELEX on Proteus mirabilis, a common cause of catheter associated urinary tract infections in long-term catheterized patients. MREs specific for two different strains of $P$. mirabilis with low nanomolar range $K_{d}$ values were identified after 6 rounds of in vitro selection. Additionally, an in silico maturation (ISM) process was performed to increase the specificity of the selected MRE. It was reported that a $36 \%$ higher specificity was achieved after the ISM process [69]. This same technique was again employed to select MRE specific for Streptococcus mutants, the main causative pathogen of dental caries. The affinity of the identified MRE was improved up to 16-fold and 
the specificity was increased 12-fold after ISM. A gold colloids based colorimetric flow-through assay was developed and demonstrated the detection $S$. mutants in the range of $10^{5}-$ $10^{8} \mathrm{CFU} / \mathrm{mL}[70]$.

Streptococcus pyogenes (Group A Streptococcus) is often the causative pathogen of a wide range of infectious diseases, such as streptococcal pharyngitis and streptococcal toxic shock syndromes [71]. Different M-types of live S. pyogenes were chosen for selection by Hamula et al. After 20 rounds of target selection, the two best candidate MREs yielded high affinity for Group A Streptococcus $\left(K_{d}=9-10 \mathrm{nM}\right)$. It was noteworthy that the candidate MREs showed good specificities, even though the authors did not perform any negative selections [72].

Staphylococcus aureus is a gram-positive bacteria associated with numerous of infections in human [73]. Cao et al. selected a panel of ssDNA MREs specific for $S$. aureus after several rounds of target and counter target selection. The reported $K_{d}$ values of individual candidate MREs were in the nanomolar range with high specificity. The study showed that the combination of the panel of MREs yielded a better sensitivity in recognizing $S$. aureus than any single MRE [74]. Change et al. selected two ssDNA MREs with high affinities and specific toward $S$. aureus $\left(K_{d}=35\right.$ and $129 \mathrm{nM})$. The reported values of $K_{d}$ improved to 3.03 and $9.9 \mathrm{nM}$, respectively, after thiol-modification and conjugation to gold nanoparticles. Subsequently, the MRE conjugated gold nanoparticles were utilized to capture target bacteria and a resonance light-scattering signal demonstrated the detection of single $S$. aureus cell in 1.5 hours [75].

Pseudomonas aeruginosa is a gram-negative bacterium that is commonly associated with nosocomial infections [76, 77]. Wang et al. performed 15 rounds of positive and 2 rounds of counter target selection to identify ssDNA MREs with $K_{d}$ values in the low nanomolar range. The selected MRE showed negligible binding to counter bacteria cell targets. A fluorescence in situ hybridization (FISH) assay was developed to show rapid detection of $P$. aeruginosa. However, the detection ranges were not reported [78].

Mycobacterium tuberculosis is the etiologic pathogen for tuberculosis [79]. Chen et al. reported ssDNA MRE with an apparent association constant $\left(K_{a}\right)$ between $10^{5}-10^{6} \mathrm{M}$ and was highly specific. The authors reported an antibacterial effect of the selected MRE with both in vitro and in vivo models [80].

Highly infectious bacteria and bacteria spores have been considered as potential biological warfare agents, and it is important to detect these biological threats rapidly [81]. Bruno and Kiel 1999 performed an in vitro selection of ssDNA MREs targeting Bacillus anthracis spores, the causative agent of anthrax. Autoclaved anthrax spores were used in the selection. MRE-magnetic bead electrochemiluminescence sandwich assay was developed with a reported detection range of $10-10^{6}$ spores [82]. Ikanovic et al. performed a selection of ssDNA MREs specific for Bacillus thuringiensis spores, a closely related species to $B$. anthracis. In this study, the methodology was adopted from Bruno and Kiel 1999. A fluorescent assay based on cadmium selenide quantum dots was developed with a reported detection limit at about $1000 \mathrm{CFU} / \mathrm{mL}$ [83]. Bruno and Carrillo 2012 revisited the selection of Bacillus spores. In this later study, anthrose sugar on anthrax spores was chosen as target for selection. MRE beacon based on fluorescent signals was developed and generated strong signal at spore concentrations greater than 30,000 spores/mL. The authors also compared the MRE sequences pattern to previous studies and identified similarities in sequences composed of $\mathrm{T} / \mathrm{G}$ rich bases. It was also reported that MREs specific for whole spores did not generate fluorescent signals in the presence of anthrose sugar, suggesting that the selected spore specific MREs possibly bound to a different epitope and warranting further research [84].

Francisella tularensis is an encapsulated, gram-negative coccobacillus that is highly infectious. Reports show as few as 25 organisms in aerosol can cause diseases [85]. Vivekananda and Kiel performed ten rounds of selection on Francisella tularensis subspecies japonica bacterial antigen. A cocktail of 25 ssDNA MREs was reported to have high specificity toward the target bacteria. MRE modified enzyme linked immunosorbent assay was developed, and demonstrated binding to the target and other subspecies of F. tularensis but not to other species of bacteria and chicken lysozyme or chicken albumin. In addition, the assay was able to achieve better sensitivity then traditional ELISA using anti-tularemia antiserum and anti-tularemia polycolonal antibodies. The reported LOD is 1700 bacteria/mL [86].

Peptidoglycan is a macromolecule universally expressed on bacteria outer cell wall [87]. Ferreira et al. identified two ssDNA MREs with sub- to low micromolar $K_{d}$ values that can bind specifically to both gram-positive and gram-negative bacteria. Neither MRE bounded to human fibroblasts or Candida albicans and could potentially be used as generic detection elements for bacteria [88].

Lipopolysaccharide (LPS or endotoxin) is expressed in the outer membrane of gram-negative bacteria and can illicit strong immune response upon entering into mammalian cells. [89, 90] Kim et al. used nonequilibrium capillary electrophoresis of equilibrium mixtures (NECEEM) based non-SELEX to identify multiple ssDNA MREs with high affinities toward lipopolysaccharide in only three rounds of selection. Selected MREs also demonstrated very low cross-binding activities to bovine serum albumin and other intracellular molecules, such as DNA, RNA, glucose, and sucrose, in an electrochemical assay. This assay resulted in a target detection range of 0.01 to $1 \mathrm{ng} / \mathrm{mL}$ [91].

2.4. Single-Stranded DNA MREs Targeting Viruses. There is a wealth of literature describing ssDNA MREs targeting various virus life cycle regulator proteins with the purpose of therapeutic application. In contrast, there is a lesser amount of research on ssDNA MREs for virus biosensing application (Table 2). For the focus of this review, those MREs with therapeutic applications are listed in the following table without further detail discussions (Table 3).

In recent years, there has been an increase in the interest in the application of ssDNA MREs for virus detection. 
TABLE 2: Summary table of ssDNA MREs targeting viruses and virus protein for biosensing applications.

\begin{tabular}{|c|c|c|c|c|c|}
\hline Target & SELEX method & $K_{d}$ & $\begin{array}{l}\text { Detection } \\
\text { method }\end{array}$ & LOD & Reference \\
\hline Human noroviruses & Antibody-bead conjugates & High nanomolar range & RT-qPCR & 10 RNA copies & {$[94]$} \\
\hline Norovirus & Nitrocellulose membrane & Low picomolar range & Electrochemical & $\begin{array}{l}180 \text { virus } \\
\text { particles }\end{array}$ & {$[93]$} \\
\hline $\begin{array}{l}\text { Norovirus II.4 capsid protein } \\
\text { VP1 }\end{array}$ & Filter & - & - & - & {$[95]$} \\
\hline Influenza A H1N1 & Microfluidic SELEX & $55.14 \pm 22.40 \mathrm{nM}$ & Bead/fluorescent & $6.4 \times 10^{-3} \mathrm{HAU}$ & {$[34]$} \\
\hline Avian influenza H5N1 & Nitrocellulose membrane & $4.65 \mathrm{nM}$ & Dot blot & $1.28 \mathrm{HAU}$ & [97] \\
\hline $\begin{array}{l}\text { Influenza A hemagglutinin } \\
\text { protein }\end{array}$ & TALON affinity resin & Low nanomolar range & Sandwich ELAA & - & {$[98]$} \\
\hline SARS-CoV N protein & Ni-NTA beads & $4.93 \pm 0.3 \mathrm{nM}$ & Western blot & - & {$[10]$} \\
\hline Bovine viral diarrhea virus & GO-SELEX & $5 \times 10^{4} \mathrm{TCID}_{50} / \mathrm{mL}$ & $\begin{array}{l}\text { SPR AuNP } \\
\text { sandwich }\end{array}$ & 800 copies $/ \mathrm{mL}$ & {$[24]$} \\
\hline $\begin{array}{l}\text { HCV envelope surface } \\
\text { glycoprotein E2 }\end{array}$ & Cell surface SELEX & $1.05 \pm 1 \mathrm{nM}$ & - & - & {$[100]$} \\
\hline $\begin{array}{l}\text { Dengue virus type- } 2 \text { envelope } \\
\text { protein domain III }\end{array}$ & Ni-NTA magnetic beads & $154 \pm 40 \mathrm{nM}$ & - & - & {$[102]$} \\
\hline HIV reverse transcriptase & CE-SELEX & $180 \pm 70 \mathrm{pM}$ & - & - & {$[103]$} \\
\hline
\end{tabular}

TABLE 3: Summary table of ssDNA MREs targeting viruses and virus proteins for therapeutic applications.

\begin{tabular}{|c|c|c|c|c|}
\hline Virus & Target & SELEX method & $K_{d}$ & Reference \\
\hline $\mathrm{HIV}$ & Reverse transcriptase & Nitrocellulose filters & - & {$[126]$} \\
\hline HIV & Reverse transcriptase & Sephadex columns & $660 \mathrm{pM}$ & {$[127]$} \\
\hline HIV & Reverse transcriptase & Nitrocellulose filters & $1 \mathrm{nM}$ & {$[128]$} \\
\hline HIV & Reverse transcriptase & Primer-free SELEX & $82 \mathrm{nM}$ & [129] \\
\hline HIV & Integrase & Nitrocellulose filters & - & {$[130]$} \\
\hline HIV & Integrase & - & - & {$[131]$} \\
\hline HIV & $\begin{array}{l}\text { Trans-activation-responsive } \\
\text { RNA (TAR) element }\end{array}$ & Magnetic beads & $20 \mathrm{nM}$ & {$[132]$} \\
\hline HIV & $\begin{array}{l}\text { Trans-activation-responsive } \\
\text { RNA (TAR) element }\end{array}$ & Magnetic beads & $50 \mathrm{nM}$ & {$[133]$} \\
\hline $\mathrm{HCV}$ & NS5B RNA polymerase & Nitrocellulose filters & $132 \mathrm{nM}$ & {$[134]$} \\
\hline $\mathrm{HBV}$ & Core protein & - & $\begin{array}{l}\text { High affinity } \\
\text { determined by dot } \\
\text { blot }\end{array}$ & {$[135]$} \\
\hline SARS coronavirus & Helicase & Magnetic beads & $5 \mathrm{nM}$ & [136] \\
\hline Influenza A virus & Hemagglutinin from $\mathrm{H} 3 \mathrm{~N} 2$ & Ni-NTA beads & - & [137] \\
\hline Influenza A virus & Hemagglutinin from H5N1 & Ni-NTA beads & $\begin{array}{l}\text { High affinity } \\
\text { determined by } \\
\text { ELISA }\end{array}$ & [138] \\
\hline Influenza A virus & Hemagglutinin from H3N2 & Ni-NTA magnetic beads & $7 \mathrm{nM}$ & {$[139]$} \\
\hline Influenza A virus & Hemagglutinin from $\mathrm{H} 9 \mathrm{~N} 2$ & Nitrocellulose filters & $\begin{array}{l}\text { High affinity } \\
\text { determined by } \\
\text { ELISA }\end{array}$ & [140] \\
\hline Influenza A virus & Nonstructural protein 1 & Glutathione agarose beads & $18.91 \pm 3.95 \mathrm{nM}$ & {$[141]$} \\
\hline Rabies virus & $\begin{array}{l}\text { Rabies virus infected BHK-21 } \\
\text { cells }\end{array}$ & Cell-SELEX & $28 \mathrm{nM}$ & [142] \\
\hline HPV & HPV transformed HeLa cells & Cell-SELEX & $1 \mathrm{nM}$ & [143] \\
\hline Vaccinia virus & Whole virus particle & One-step MonoLEX & $\begin{array}{l}\text { High affinity } \\
\text { determined by dot } \\
\text { blot, SPR, and so } \\
\text { forth }\end{array}$ & {$[144]$} \\
\hline
\end{tabular}


Human noroviruses are the leading cause of acute gastroenteritis worldwide. Current detection methods for the virus are time-consuming and labor intensive [92]. Giamberardino et al. performed nine rounds of in vitro selection on murine norovirus. The best candidate MRE was reported to have affinity in the low picomolar range. It displayed cross-binding activity with human norovirus but not to a structurally similar virus, feline calicivirus. An electrochemical sensor using a gold nanoparticle modified screen-printed carbon electrode was developed with a reported LOD of 180 virus particles [93]. Escudero-Abarca et al. performed selection on multiple strains of human noroviruses, including Snow Mountain virus and Norwalk virus. Candidate MREs showed high binding affinities that were comparable to commercially available antibodies. The best MRE was also able to show binding to specific virus strains in human fecal samples. A reported LOD of 10 virus RNA copies was achieved in artificially contaminated lettuce by using immobilized biotinylated MRE on streptavidin magnetic beads coupled with real-time quantitative PCR [94]. The capsid protein VP1 of Norovirus genotype II. 4 was chosen to be the target for selection by Beier et al. After twelve rounds of selection, surface plasmon resonance analysis was used to show the high specificity of the selected MRE. Computer simulation was used to characterize the binding interaction between VP1 and candidate MREs. However, the authors did not report the $K_{d}$ in the study [95].

Influenza virus is the causative agent for many upper respiratory diseases and can potentially cause pandemics with high mobility and mortality [96]. Lai et al. used MSELEX to identify ssDNA MRE target influenza A H1N1 with high affinity $\left(K_{d}=55.14 \pm 22.40 \mathrm{nM}\right)$. A magnetic bead based florescent assay achieved a reported LOD of $6.4 \times 10^{-3} \mathrm{HAU}$. When the bead capturing method was coupled with RTPCR, the fluorescent signal remained detectable in virus spiked clinically relevant matrices, including throat swab samples, sputum samples, and serum samples [34]. Wang et al. performed an in vitro selection specific for influenza virus H5N1. Purified hemagglutinin (HA) protein was used as target for the first four rounds and then inactivated whole $\mathrm{H} 5 \mathrm{~N} 1$ viruses were used from round five to thirteen. The best candidate MRE displayed high affinity $\left(K_{d}=4.65 \mathrm{nM}\right)$ with only minimal cross-binding activities on other avian influenza virus strains. A dot blot assay was developed with a LOD of 1.28 HAU, which was comparable to antiH5 antibody. The dot blot assay also demonstrated the detection of the target virus in spiked chicken and duck swab samples [97]. Shiratori et al. chose recombinant influenza A HA protein as a target for selection. After ten rounds of target selection, candidate sequences showed high binding affinities with reported $K_{d}$ values in the low nanomolar range. A sandwich enzyme linked aptamer assay (ELAA) was developed and showed similar binding responses on three strains of influenza A, H5N1, H1N1, and H3N2. However, the LOD was not determined [98].

A novel coronavirus caused a severe acute respiratory syndrome (SARS) outbreak in 2002 to 2003 [99]. Cho et al. identified ssDNA MREs specific for the SARS coronavirus nucleocapsid protein. After twelve rounds of positive selection, the best candidate MRE had a reported $K_{d}$ of $4.93 \pm$ 0.3 nM. MRE modified Western blot showed a comparable detection level to nucleocapsid antibody based assay. However, the authors did not show cross-reactivity of the selected MREs toward other viral proteins [10].

GO-SELEX was utilized to identify ssDNA MREs specific for bovine viral diarrhea virus. After five rounds of positive and negative selections, three best candidate MREs had reported $K_{d}$ values of $4.08 \times 10^{4}, 4.22 \times 10^{4}$, and $5.2 \times 10^{4} \mathrm{TCID}_{50} / \mathrm{mL}$, respectively, by SPR kinetics analysis. All candidate MREs showed very high specificity toward the target. A sandwich SPR detection assay was developed wherein a biotinylated MRE was immobilized on streptavidin coated gold chip as the capturing MRE, and a second different MRE with thiol modification was conjugated to gold nanoparticle as the reporting MRE. A LOD of 800 copies of virus/mL was reported with this assay [24].

Hepatitis C virus (HCV) envelope surface glycoprotein E2 was chosen as target for selection by Chen et al. E2 protein was expressed on a murine colon carcinoma cell line, CT26 cells, and used as a target for positive selection. The native CT26 cells were used as counter target. After 13 rounds of selection, the best candidate MRE showed high affinity and specificity toward E2-positive cells. An ELISA virus capture assay was developed by using biotinylated MRE as reporter and demonstrated the detection of $\mathrm{HCV}$ in clinical human serum samples. In addition, the MRE, termed ZE2 also displayed therapeutic effect by inhibiting E2 protein binding to CD81 and blocking HCV infection of human hepatocytes in vitro [100].

Dengue virus is a member of family Flaviviridae, genus flavivirus. It is a mosquito-borne RNA virus that can cause gangue fever, dengue hemorrhagic fever, and dengue shock syndrome [101]. Gandham et al. used recombinant dengue virus type-2 envelope protein domain III as target of interest to perform an in vitro selection of thiophosphate ester modified ssDNA MREs. After five rounds of target selection, the best MRE had a reported $K_{d}$ of $154 \pm 40 \mathrm{nM}$, but no crossbinding experiments were performed [102].

CE-SELEX was performed by Mosing et al. to identify ssDNA MREs specific for HIV reverse transcriptase. After only four rounds of selection, the best candidate MRE had an ultrahigh affinity with a reported $K_{d}$ in the picomolar range. Interestingly, there were no identifiable consensus sequence families in the round four ssDNA library. The authors claimed that the selected MRE had the highest affinity for the target of interest when compared to MREs selected by other methods and suggested that multiple ultrahigh affinity MREs might exist in the enriched library [103].

\subsection{Single-Stranded DNA MREs Targeting Toxins}

2.5.1. Biological Toxins/Virulence Factors. Secretory proteins, virulent factors, exotoxins, or small molecule toxins from bacteria, fungus, and other organisms are important biomarkers in medical diagnosis, environmental monitoring, and food safety surveillance. The following section discusses 
recent studies in the identification and biosening application of ssDNA MREs specific for biological toxins (Table 4).

Staphylococcus aureus can secrete a group of thermostable enterotoxins that have been shown to contaminate food. Reports suggest that these toxins are a common cause of foodborne illnesses [104]. There are many types and subtypes of staphylococcus enterotoxins. Bruno and Kiel first selected ssDNA MREs that bind to enterotoxin B by using magnetic bead immobilized target. An electrochemiluminescence assay was developed to demonstrate a detection limit of less than $10 \mathrm{pg}$ of enterotoxin B. However, no kinetic data or crossing-binding profiles were presented in the study [105]. DeGrasse recently identified ssDNA MRE specific for enterotoxin $\mathrm{B}$ after fourteen rounds of mixed target and negative targets selection. MRE based precipitation assay was used to analyze the selectivity of candidate MREs in cellfree culture supernatant from multiple strains of $S$. aureus. The high selectivity of candidate MREs was confirmed by capturing only the target toxin in the precipitation assay. However, no quantitative binding data was presented in the study [11]. Enterotoxin subtype $\mathrm{Cl}$ was chosen as a target for selection by Huang et al. After twelve rounds of selection, the best candidate MRE demonstrated high affinity for enterotoxin $\mathrm{C} 1\left(K_{d}=65.14 \pm 11.64 \mathrm{nM}\right)$. Crossbinding experiments showed that the selected MRE had high specificity and low cross-binding activities on staphylococcus enterotoxin A, enterotoxin B, and other protein molecules. A graphene oxide based fluorescence detection assay was developed and achieved a reported LOD of $6 \mathrm{ng} / \mathrm{mL}$ in artificially contaminated buffer-diluted milk samples [106].

Bruno and Kiel 2002 selected ssDNA MRE against cholera toxin. An enzyme linked colorimetric assay showed a detection limit of less than $10 \mathrm{ng}$ of cholera toxin and electrochemiluminescence assay shows a detection limit of less than $40 \mathrm{ng}$. However, affinity, crossing-binding data, and MRE sequences were not presented in the study [105].

Toxigenic strains of Clostridium difficile can produce toxins $\mathrm{A}$ and toxin $\mathrm{B}$, which are the contributing factor of $C$. difficile induced diarrhea. Rapid diagnosis of the condition is crucial in facilitating patient recovery and disease control [107]. Some strains of $C$. difficile also secret a binary toxin that can inhibit actin polymerization [108]. Ochsner et al. selected several slow off-rate modified ssDNA MREs (SOMAmer) specific for toxins A, B, and binary toxin. Several DNA libraries with modifications, such as 5-benzylaminocarbonyldU (BndU), 5-naphthylmethylaminocarbonyl-dU (NapdU), 5-tryptaminocarbonyl-dU (TrpdU), 5-phenylethyl-1-aminocarbonyl (PEdU), 5-tyrosylaminocarbonyl-dU (TyrdU), or 5-(2-naphthylmethyl) aminocarbonyl (2NapdU) were used in selections. Truncated recombinant toxins were used as targets. Equilibrium dissociation constants of selected SOMAmers were in pico to nanomolar range. The affinities for native toxins were slightly lower but were remain in the low nanomolar range for majority of the candidate sequences. Pull-down capture, dot blots, and antibody sandwich assays were developed with a reported LOD of $300 \mathrm{pg} / \mathrm{mL}$. Selected SOMAmers were able to detect all three toxins in cellfree culture supernatants of toxigenic C. difficile [109]. Ochsner et al. performed another in vitro selection on
C. difficile binary toxin with sandwich SELEX. The advantage of sandwich SELEX is to select SOMAmer pairs that target different epitopes of the target protein. The reported $K_{d}$ values of selected SOMAmers ranged from 0.02 to $2.8 \mathrm{nM}$. A SOMAmer sandwich assay was developed with a reported LOD in the low picomolar range. The authors claimed that these studies showed the high potential for the development of sensitive and specific diagnostic kits [110].

Hong et al. performed twelve rounds of positive in vitro selection against $C$. difficile toxin B and eleven rounds of negative selection. SPR binding study determined the selected ssDNA MRE had a $K_{d}$ value of $47.3 \pm 13.7 \mathrm{nM}$. Fluorescence plate based cross-binding assay showed the selection ssDNA MRE was two to five times more selective on toxin $B$ than negative targets. A proof-of-concept modified ELISA using ssDNA as the toxin capturing element was developed and able to detect toxin $\mathrm{B}$ at $50 \mathrm{nM}$ concentration in human fecal matter [111].

Tuberculosis (TB) remains to be a challenging disease in developing countries. Recent discovery of multidrug resistant strains of Mycobacterium tuberculosis has further increased public concerns, however, current diagnostic techniques for TB are either time-consuming or insensitive [112-114]. Rotherham et al. performed a selection on CFP-10.ESAT6 heterodimer, a specific biomarker for TB infections. After six rounds of selection, SPR binding studies showed that candidate ssDNA MREs had affinities in the nanomolar range. One of the candidate MRE was tested in an enzyme linked oligonucleotide assay (ELONA). The authors reported that the assay had $100 \%$ sensitivity and $68.75 \%$ specificity in clinical sputum samples using Youden's index. However, the time needed for assay completion and crossing-binding activities to other antigens were major limitations of the assay [9]. Tang et al. performed a selection on the same CFP-10.ESAT6 heterodimer. After seventeen rounds of selection, $K_{d}$ values of candidate MREs were in the low nanomolar range. Two ssDNA MREs (CE24, CE15) were used in an ELONA assay. The reported sensitivity and specificity of CE24 MRE based ELONA were 100\% and 94.1\%, respectively. CE15 MRE based ELONA had a lower sensitivity of $89.6 \%$, but the specificity was the same. Assays were tested both pulmonary and extrapulmonary with serum samples from TB patients [115].

MPT64 is a secreted protein of $M$. tuberculosis and can be used as biomarker for active TB infections [116]. Qin et al. performed twelve rounds of selection on MPT64. Affinities of truncated candidate ssDNA MREs, containing only a 35-base central random region, were qualitatively observed using streptavidin-horse radish peroxidase (HRP) binding to protein-bound biotin-tagged MREs. A colorimetric sandwich assay using two different MREs was developed to detect the presence of MPT64 in culture filtrates. The sandwich assay achieved sensitivity and specificity of $86.3 \%$ and $88.5 \%$, respectively [117].

Protective antigen (PA) is a secreted virulence factor of Bacillus anthracis that binds to anthrax toxin receptors on mammalian cells and subsequently causes cell dysfunction and death [118]. Cella et al. utilized CE-SELEX to identify ssDNA MRE targeting PA with high affinity and specificity. After six rounds of CE-SELEX, the best candidate had 
TABLE 4: Summary table of ssDNA MRE targeting biological toxins and virulence factors.

\begin{tabular}{|c|c|c|c|c|c|}
\hline Target & SELEX method & $K_{d}$ & Detection method & LOD & Reference \\
\hline Enterotoxin B & Magnetic beads & - & Electrochemiluminescence & $10 \mathrm{pg}$ & {$[105]$} \\
\hline Enterotoxin B & Magnetic beads & - & - & - & [11] \\
\hline Enterotoxin $\mathrm{C} 1$ & Magnetic beads & $65.14 \pm 11.64 \mathrm{nM}$ & Fluorescence & $6 \mathrm{ng} / \mathrm{mL}$ & {$[106]$} \\
\hline Cholera toxin & Magnetic beads & - & ELAA/electrochemiluminescence & $\begin{array}{l}10 \mathrm{ng} \\
40 \mathrm{ng}\end{array}$ & {$[105]$} \\
\hline $\begin{array}{l}\text { C. difficile toxin A/toxin } \\
\text { B/binary toxin }\end{array}$ & $\begin{array}{l}\text { Magnetic } \\
\text { Beads/SOMAmer }\end{array}$ & $\begin{array}{l}\text { Sub- to low } \\
\text { nanomolar range }\end{array}$ & Various & $1 \mathrm{pmol} / \mathrm{L}$ & [109] \\
\hline C. difficile binary toxin & $\begin{array}{l}\text { Sandwich } \\
\text { SELEX/SOMAmer }\end{array}$ & $0.02-2.7 \mathrm{nM}$ & Sandwich assays & Low picomolar & {$[110]$} \\
\hline C. difficile toxin $\mathrm{B}$ & Magnetic beads & $47.3 \pm 13.7 \mathrm{nM}$ & Modified ELISA & $50 \mathrm{nM}$ & {$[111]$} \\
\hline $\begin{array}{l}\text { CFP-10.ESAT-6 } \\
\text { heterodimer }\end{array}$ & Nitrocellulose & $\begin{array}{l}\text { Low nanomolar } \\
\text { range }\end{array}$ & Colorimetric (ELONA) & $\begin{array}{l}\text { 100\% sensitivity, } \\
68.75 \% \\
\text { specificity }\end{array}$ & {$[9]$} \\
\hline $\begin{array}{l}\text { CFP-10.ESAT- } 6 \\
\text { heterodimer }\end{array}$ & Microwell plate & $375 \mathrm{nM} / 160 \mathrm{nM}$ & Colorimetric (ELONA) & $\begin{array}{l}89.6-100 \% \\
\text { sensitivity, } \\
94.1 \% \text { specificity }\end{array}$ & [115] \\
\hline $\begin{array}{l}\text { MPT64 } \\
\text { TB protein }\end{array}$ & Microwell plate & - & Sandwich assays & - & {$[117]$} \\
\hline Protective antigen & CE-SELEX & $112 \mathrm{nM}$ & Electrochemical (SWNT) & $1 \mathrm{nM}$ & {$[119]$} \\
\hline Protective antigen & Membrane filtration & Nanomolar range & ELISA & - & {$[120]$} \\
\hline $\begin{array}{l}\text { Botulinum neurotoxin } \\
\text { type A heavy chain } \\
\text { peptide/toxoid }\end{array}$ & Single microbead & $\begin{array}{l}\text { Nano- to } \\
\text { micromolar range }\end{array}$ & - & - & {$[30]$} \\
\hline $\begin{array}{l}\text { Botulinum neurotoxin } \\
\text { type A light chain }\end{array}$ & Microfluidic-SELEX & $\begin{array}{l}\text { Low nanomolar } \\
\text { range }\end{array}$ & - & - & {$[32]$} \\
\hline $\begin{array}{l}\text { Botulinum neurotoxin } \\
\text { type A light chain }\end{array}$ & Magnetic beads & - & Fluorescence & $1 \mathrm{ng} / \mathrm{mL}$ & {$[122]$} \\
\hline Microcystin & Sepharose gel & $K_{a}: 10^{3} \mathrm{M}^{-1}$ & SPR & - & {$[123]$} \\
\hline Cylindrospermopsin & Sepharose beads & $88.78 \mathrm{nM}$ & Electrochemical & $100 \mathrm{pM}$ & {$[125]$} \\
\hline Saxitoxin & Magnetic beads & - & - & - & [145] \\
\hline Okadaic acid & Magnetic beads & $77 \mathrm{nM}$ & Electrochemical & $70 \mathrm{pg} / \mathrm{mL}$ & {$[12]$} \\
\hline Ochratoxin A & Agarose resin & $200 \mathrm{nM}$ & Fluorescence polarization & $5 \mathrm{nM}$ & {$[146,147]$} \\
\hline Ochratoxin A & Magnetic beads & $96-293 \mathrm{nM}$ & ELAA & $1 \mathrm{ng} / \mathrm{mL}$ & {$[148]$} \\
\hline Ochratoxin A & Sepharose beads & $\begin{array}{l}\text { High nanomolar } \\
\text { range }\end{array}$ & Fluorescence & $9 \mathrm{nM}$ & {$[149]$} \\
\hline Fumonisin $\mathrm{B}_{1}$ & Magnetic beads & $100 \mathrm{nM}$ & - & - & {$[13]$} \\
\hline Zearalenone & Magnetic beads & $41 \pm 5 \mathrm{nM}$ & Fluorescence & $0.785 \mathrm{nM}$ & {$[150]$} \\
\hline T-2 toxin & GO-SELEX & $20.8 \pm 3.1 \mathrm{nM}$ & Fluorescence & $0.4 \mu \mathrm{M}$ & {$[151]$} \\
\hline Aflatoxin B1 & Magnetic beads & $11.39 \pm 1.27 \mathrm{nM}$ & Fluorescence & $35 \mathrm{ng} / \mathrm{L}$ & {$[152]$} \\
\hline Aflatoxin B1/M1 & Magnetic beads & $\begin{array}{l}96-221 \mathrm{nM} \\
35-1515 \mathrm{nM}\end{array}$ & Colorimetric/AuNPs & $\begin{array}{l}\text { 250-500 nM } \\
\text { (Aflatoxin M1) }\end{array}$ & [153] \\
\hline Alpha-bungarotoxin & 1 step SELEX & $7.58 \mu \mathrm{M}$ & - & - & {$[31]$} \\
\hline Alpha toxin & Magnetic beads & $93.7 \pm 7 \mathrm{nM}$ & Modified ELISA & $200 \mathrm{nM}$ & {$[154]$} \\
\hline Alpha toxin & Filter & - & - & - & {$[155]$} \\
\hline
\end{tabular}

a reported $K_{d}$ of $112 \mathrm{nM}$. An electrochemical biosensor was developed by immobilizing $5^{\prime}$ amino modified MRE on 1-pyrenebutanoic acid succinimidyl ester (PASE) modified single wall carbon nanotubes (SWNT). The sensor showed low cross-binding activity toward human and bovine serum albumin at $100 \mathrm{nM}$ concentration. The sensor surface could be regenerated using $1 \mu \mathrm{L}$ of $6 \mathrm{M}$ guanidine hydrochloride for 15 minutes followed by a wash with $10 \mathrm{mM}$ phosphate buffer. A reported LOD of $1 \mathrm{nM}$ was achieved [119]. Choi et al. performed an in vitro selection on PA. After eight rounds of selection, four candidate sequences had high affinities for PA ( $K_{d}$ in low nanomolar range), and two of the four 
candidates had low cross-binding activities toward bovine serum albumin and bovine serum [120].

Botulinum neurotoxins (BoNT) are produced by Clostridium botulinum. In addition to its medical uses, it can also cause serious foodborne illness and may potentially be used as a biological weapon [121]. Tok and Fischer used a novel single microbead SELEX to perform selection of ssDNA MREs specific to aldehyde-inactivated BoNT type A toxin (BoNT/A-toxoid) and BoNT type A heavy chain peptide (BoNT/A Hc-peptiod). Targets were immobilized onto Ni-NTA agarose or amine-functionalized polystyrene TentaGel beads. A single target-immobilized microbead was incubated with the ssDNA library and retrieved for PCR amplification of bound ssDNA molecules. After only two rounds of selection, five candidate sequences specific for BoNT/A Hc-peptiod had $K_{d}$ values ranging from $1.09 \mu \mathrm{M}$ to $4.20 \mu \mathrm{M}$. Three candidate sequences specific for BoNT/Atoxoid had $K_{d}$ values ranging from $3 \mathrm{nM}$ to $51 \mathrm{nM}$. The authors reported that all MREs specific to BoNT/A Hc- peptoid were able to competitively inhibit the binding between the toxin peptide and anti-BoNT antibody and potentially be used as a therapeutic agent [30].

Lou et al. utilized a novel microfluidic device to facilitate the partitioning of a small volume of target coated magnetic beads (M-SELEX). The library achieved a very high overall affinity $\left(K_{d}=33 \pm 8 \mathrm{nM}\right)$ against BoNT/A light chain after only one round of selection. Four candidate sequences had a range of $K_{d}$ values between 34 and $86 \mathrm{nM}$. The authors claimed that their M-SELEX could be readily adapted to any bead immobilized targets or whole cell target [33]. Bruno et al. immobilized BoNT/A light chain on magnetic beads and performed 10 rounds of selection. The best candidate MRE was fluorescently tagged and used as a reporter for target detection. The reported LOD of $1 \mathrm{ng} / \mathrm{mL}$ was achieved in buffer. However, the MRE reporter also bound to structurally similar targets, BoNT type B, type E holotoxins, and heavy or light chain components, in a soil dilution. The author compared their MRE sequence to previous ssDNA MRE specific for BoNT and found consensus short sequence segments. This suggested that the binding between BoNTs and MREs may be conserved within these consensus segments [122].

Microcystin is a hepatotoxin produced by cyanobacteria. Three different analogs of microcystin were used in the study performed by Nakamura et al. Microrocystin LR, containing a leucine substituent, was immobilized and used for twelve rounds of target selection. However, surface plasmon resonance binding data indicated a higher binding level between the selected MRE and microcystin YR, an analog containing a tyrosine substituent. There was also significant binding to microcystin $\mathrm{RR}$, an analog containing an arginine substituent. The reported binding affinity $\left(K_{a}\right)$ was low, at approximately $10^{3} \mathrm{M}^{-1}$. This early work did not demonstrate the high affinity and specificity properties of MREs; however, it did show the possibility of using MREs as a binding molecule in a label-free detection system [123].

Cylindrospermopsin (CYN) is another water soluble and heat stable alkaloid secreted by a large group of fresh water cyanobacteria. It has a variety of toxic effects in human bodies upon exposure to cylindrospermopsin usually through drinking water or food [124]. Elshafey et al. recently selected ssDNA MRE with high affinity and specificity toward CYN, with a reported $K_{d}$ of $88.78 \mathrm{nM}$. Circular dichroism measurements showed that MRE had a conformational change upon binding to CYN. This property was exploited in a labelfree impedimetric biosensor. The reported LOD of the sensor was $100 \mathrm{pM}$ with a linear range of $80 \mathrm{nM}$. It also showed negligible responses toward coexistent cyanobacterial toxins of microcystin-LR and Anatoxin-a. CYN was recoverable in a spike test with tap water [125].

Saxitoxin is a small neurotoxin produced by few dinoflagellates and certain cyanobacteria that affect marine organisms [248]. Handy et al. were the first to select ssDNA MRE against target saxitoxin. In their study, saxitoxin was conjugated to keyhole limpet hemocyanin (KLH) via a spacer compound, $2,2^{\prime}$-(ethylenedioxy)bis(ethylamine), or JEFFAMINE and then the protein-toxin conjugate immobilized on magnetic beads. Ten rounds of selection were performed, and negative selection against KLH-bead was carried out from round four to the round ten, in order to decrease nonspecific binding to KLH and beads. One candidate sequence was analyzed by SPR and demonstrated a concentration-dependent and selective binding to saxitoxins. However, the $K_{d}$ of the selected MRE was not presented in the study [145].

Okadaic acid (OA) is a phycotoxin produced by Dinophysis and Prorocentrum algae. It can accumulate in shellfish due to its lipophilic and heat-stable nature. Human consumption of OA can lead to a variety of gastrointestinal symptoms [249]. Eissa et al. identified ssDNA MRE with high affinity and specificity toward OA after eighteen rounds of mixed target and negative target selection. The candidate MRE with the highest affinity $\left(K_{d}=77 \mathrm{nM}\right)$ was chosen for circular dichroism analysis. A conformational change in the MRE was observed upon binding of OA. A label-free electrochemical impedimetric biosensor was developed with this MRE and achieved a LOD of $70 \mathrm{pg} / \mathrm{mL}$. It demonstrated no crossbinding activity toward structurally similar toxins, including dinophysis toxins- 1 and -2 and microcystin-LR [12].

Ochratoxin A (OTA) is a mycotoxin produced by members of the Aspergillus and Penicillium genera. It is a nephrotoxin and has potential carcinogenic effects in humans. It has been shown as a contaminant in many food products, such as grains and wine [250]. However, the current detection method for OTA is both expensive and time-consuming [251]. Cruz-Aguado and Penner identified ssDNA MRE specific for OTA after thirteen rounds of selection. The best candidate MRE reported had a $K_{d}$ value of $200 \mathrm{nM}$. It did not bind nonspecifically to warfarin, $\mathrm{N}$-acetyl-L-phenylalanine, or ochratoxin B in a fluorescent based cross-binding assay [146]. Subsequently, the authors developed a detection system based on a fluorescence polarization displacement assay. The author reported that the assay was sensitive to OTA but not to warfarin and N-acetyl-L-phenylalanine, with a LOD of $5 \mathrm{nM}$. However, the detection assay did not test ochratoxin B (OTB) binding activity or sensitivity in food sample [147]. Barthelmebs et al. also selected ssDNA MRE specific for OTA. Several candidate MREs were identified after fourteen 
rounds of selection. After binding and cross-binding analysis, the best candidate had a $K_{d}$ value of $96 \mathrm{nM}$ with minimal binding to OTB and phenylalanine. It was incorporated into an ELISA and ELAA assays for the detection of OTA spiked in pretreated wine samples. Different ELAA and ELISA assays were compared, and a direct competitive ELAA had the lowest detection limit of $1 \mathrm{ng} / \mathrm{mL}$ with the shortest analysis time of 125 minutes [148]. McKeague et al. performed fifteen rounds of in vitro selection to identify ssDNA MREs specific for OTA. Two candidate MREs had reported $K_{d}$ values of $110 \pm 50 \mathrm{nM}$ (designated B08) and $290 \pm 150 \mathrm{nM}$ (designated A08). A08 ssDNA MRE was utilized in a labelfree fluorescence detection assay and achieved a LOD of $9 \mathrm{nM}$. It also had low cross-binding activity on OTB and warfarin. The authors reported a truncated version of A09 also had similar specificity and binding affinity profiles [149].

Fumonisins are heat-stable mycotoxins present in most corn and are produced by fungi, Fusarium verticillioides and Fusarium proliferatum. Fumonisin $\mathrm{B}_{1}\left(\mathrm{FB}_{1}\right)$ is a nephrotoxin and potential carcinogen in humans. As the toxin cannot be inactivated by cooking in high temperature, it is crucial to monitor its level during food production [252]. McKeague et al. performed eight rounds of selection to identify ssDNA MRE with high binding affinity toward $\mathrm{FB}_{1}$. Unmodified magnetic beads (immobilization substrate), L-homocysteine, L-cysteine, and L-methionine L-glutamic acid were used as negative targets in the selection. Six candidate MREs were identified, and the best candidate MRE had a reported $K_{d}$ of $100 \mathrm{nM}$. However, the authors did not test the specificity of the selected MRE on other mycotoxins [13].

Zearalenone (ZEN; F-2 toxin) is a nonsteroidal estrogenic mycotoxin produced by many fungus species in the Fusarium genus. It has been shown to be present in many grains worldwide, such as oats, wheat, rice, and their derived food products [253]. Chen et al. performed fourteen rounds of selection, and the best candidate MRE had reported $K_{d}$ of $41 \pm 5 \mathrm{nM}$ and high specificity. Cross-binding assays showed insignificant binding to other mycotoxins, $\beta$-zearalenol, aflatoxin $B 1$, aflatoxin $B 2$, fumonisin $B_{1}$, and fumonisin $B_{2}$. Circular dichroism measurement showed a conformational change of the MRE after binding of zearalenone. A detection assay using MRE immobilized magnetic beads and the bluegreen florescence property of zearalenone was developed. A LOD of $0.785 \mathrm{nM}$ was achieved in pretreated beer samples [150].

T-2 toxin (T-2) is a trichothecene mycotoxins produced by many species in the Fusarium genus and is harmful to humans. It is a very stable small molecule biological toxin that is resistant to high temperature and is present in variety of grains, such as oats, barley, and wheat. Currently, it can only be detected by labor intensive and costly instruments and it is thus difficult to monitor its level in food [254]. Chen et al. recently utilized ten rounds of GO-SELEX to identify ssDNA MRE specific for T-2 with high affinity and specificity. Fluorescent binding and cross-binding assay showed that the $K_{d}$ of the best candidate MRE was in the nanomolar range, with insignificant cross-binding activities on $\mathrm{FB}_{1}, \mathrm{ZEN}, \mathrm{OTA}$, and aflatoxin B1. There was a conformational change upon MRE-T-2 binding. The authors also developed a fluorescent assay to detect spiked T-2 level in beer. A LOD of $0.4 \mu \mathrm{M}$ was achieved [151].

Aflatoxins are highly toxic natural compounds produced by many species of filamentous fungi and can contaminate agricultural products. The $\mathrm{LD}_{50}$ can be as low as $0.5 \mathrm{mg} / \mathrm{kg}$, and acute toxicity is even higher than many chemical toxins, such as cyanide or arsenic [255, 256]. Ma et al. performed an in vitro selection on a subtype of aflatoxins, aflatoxins B1 (AFB1). After ten rounds of target and negative target selection, the best candidate MRE had a reported $K_{d}$ of $11.39 \pm 1.27 \mathrm{nM}$ and with minimal cross-binding activities on aflatoxins B2, G1, G2, OTA, and $\mathrm{FB}_{1}$. A fluorescent assay similar to the authors' previous study on ZEN and T-2 specific MRE was developed to detect spiked levels of AFB1 in methanol-extracted peanut oil. The assay achieved a LOD of $35 \mathrm{ng} / \mathrm{L}$ [152]. Malhotra et al. perform two selections (SELEX1 and SELEX2) using slightly different methodologies to identify ssDNA MREs specific for both AFB1 and aflatoxins M1 (AFM1). In SELEX1, lambda exonuclease was used to generate ssDNA from amplified dsDNA. AFM1 coated magnetic beads were used as a positive target from round 1 to round 10, and AFB1 coated magnetic beads were used as positive target at round 11 (last round) only. Free targets were used to competitively elute ssDNA that bound to toxin coated beads in round 10 and round 11. In SELEX 2, each round started from preincubation with counter targets (uncoated beads, AFB1 beads) followed by incubation with AFM1 beads. Snap cooling was used to obtain ssDNA from dsDNA. In SELEX 2, only eight rounds were carried out. Multiple candidate MREs were analyzed and their $K_{d}$ values were in the nanoto low micromolar range. One MRE with the best affinity $\left(K_{d}=35.6 \pm 2.9 \mathrm{nM}\right)$, designated AFAS3, was used in developing a colorimetric assay based on MRE immobilized gold nanoparticles. This assay had a detection range of 250 to $500 \mathrm{nM}$ of AFM1 and only minor interaction with AFB1. However, there were no reported cross-binding data on other mycotoxins [153].

Two studies identified ssDNA MREs specific for biological toxins with therapeutic intentions. Alpha-Bungarotoxin is a toxic substance in krait snake venom and can bind irreversibly to acetylcholine receptors and eventually lead to death in victims $[257,258]$. Lauridsen et al. performed a rapid one-step SELEX and identified ssDNA MRE with relatively high binding affinity toward Alpha-Bungarotoxin $\left(K_{d}=\right.$ $7.58 \mu \mathrm{M})$. The authors claimed that rapid selection technique could potentially be used with a chemically modified nucleic acid library and generate MREs suitable for diagnostic and therapeutic purposes [31].

Vivekananda et al. selected ssDNA MRE specific for alpha-toxin of Staphylococcus aureus. Several candidate sequences showed cell rescuing effects when coadministrated with alpha toxin in multiple in vitro neutralization assays. The authors claimed that it was possible to generate MREs against alpha-toxin for the treatment of S. aureus infections [155].

Hong et al. also performed an in vitro selection against $S$. aureus alpha toxin. Twelve rounds of positive and eleven rounds of negative rounds of negative selection were performed to identify the candidate ssDNA MRE. The reported $K_{d}$ determined by SPR single cycle kinetics was $93.7 \pm 7 \mathrm{nM}$. 
TABLE 5: Summary table of ssDNA MREs targeting chemical toxins.

\begin{tabular}{|c|c|c|c|c|c|}
\hline Target & SELEX method & $K_{d}$ & Detection method & LOD & Reference \\
\hline $17 \beta$-estradiol (E2) & Sepharose column & $0.13 \mu \mathrm{M}$ & Electrochemical & $0.1 \mathrm{nM}$ & {$[156]$} \\
\hline $17 \beta$-estradiol (E2) & Sepharose column & $50 \mathrm{nM}$ & $\begin{array}{l}\text { Dynamic light scattering, } \\
\text { resistive pulse sensing }\end{array}$ & $5 \mathrm{nM}-100 \mathrm{nM}$ & {$[157]$} \\
\hline Bisphenol A & Epoxy-activated resin & $8.3 \mathrm{nM}$ & Fluorescence & Nanomolar range & {$[158]$} \\
\hline Polychlorinated biphenyls & FluMag-SELEX & $\begin{array}{l}\text { Low micromolar } \\
\text { range }\end{array}$ & Fluorescence & 0.1 to $100 \mathrm{ng} / \mathrm{mL}$ & {$[159]$} \\
\hline Polychlorinated biphenyls & Magnetic beads & Nanomolar range & - & - & {$[160]$} \\
\hline Atrazine & CE-SELEX & $890 \mathrm{nM}$ & Fluorescence polarization & - & {$[161]$} \\
\hline Atrazine & Magnetic beads & $0.62 \pm 0.21 \mathrm{nM}$ & $\begin{array}{l}\text { Magnetic beads capturing } \\
\text { coupled with CE }\end{array}$ & Nanomolar range & {$[14]$} \\
\hline Malathion & Magnetic beads & $1.14 \pm 0.7 \mathrm{nM}$ & - & - & {$[15]$} \\
\hline Bromacil & Magnetic beads & $9.6 \pm 7.8 \mathrm{nM}$ & - & - & {$[16]$} \\
\hline $\begin{array}{l}\text { Tebuconazole } \\
\text { Mefenacet } \\
\text { Inabenfide }\end{array}$ & GO-SELEX & $10-100 \mathrm{nM}$ & Colorimetric & $100-400 \mathrm{nM}$ & {$[25]$} \\
\hline $\begin{array}{l}4 \text { organophosphorus } \\
\text { pesticides phorate, } \\
\text { profenofos, isocarbophos, } \\
\text { and omethoate }\end{array}$ & $\begin{array}{l}\text { Filtration } \\
\text { column/immobilization } \\
\text { free }\end{array}$ & $\begin{array}{l}\text { Low micromolar } \\
\text { range }\end{array}$ & - & - & {$[28]$} \\
\hline Acetamiprid & Immobilization free & $4.98 \mu \mathrm{M}$ & - & - & {$[27]$} \\
\hline
\end{tabular}

Fluorescence plate based cross-binding assay showed the ssDNA MRE was approximately two to five times more selective on the alpha toxin than negative targets. A proofof-concept modified ELISA using the selected ssDNA MRE had a reported sensitive target detection at $200 \mathrm{nM}$ in human serum [154].

2.5.2. Chemical Toxins. The detection of chemical toxins is important in both food safety and environmental monitoring. Environmental and food contamination by various kinds of chemical toxins have been reported and even at low concentrations can still be detrimental to human health. Currently, the majority of small chemical toxins can only be detected by labor intensive and costly laboratory equipment such as liquid and/or gas chromatography coupled with mass spectrometry. In order to address these current limitations, there has been an increase in the identification and biosensing applications of MREs with high affinity and specificity to capture and detect chemical toxins. However, the in vitro selection of ssDNA MREs targeting small molecule chemical toxins has several inherent challenges, such as difficulties in efficient separation between bound and unbound DNA molecules, limited chemical motifs on target surfaces for sufficient binding, lack of chemical functional groups for target immobilization, and candidate MREs that may not have sufficient specificities to distinguish molecules with very similar chemical structures if selection schemes are not carefully designed. For these reasons, there are a limited number of ssDNA MREs specific for chemical toxins currently in the literature (Table 5).

Kim et al. identified a 76-mer ssDNA MRE specific for 17beta-estradiol (E2) with a $K_{d}$ of $0.13 \mu \mathrm{M}$ after seven rounds of selection. Specificity of the selected MRE was shown by square wave voltammetry (SWV) measurement, with only minimal binding to structurally similar organic chemicals 2-methoxynaphthalene and 1-aminoanthraquinone. The authors initially attempted SPR for the detection of E2. However, due to the small molecular weight of E2, there were no observable binding events by SPR. An electrochemical platform measured under SWV was eventually utilized to detect E2 with a LOD of $0.1 \mathrm{nM}$ in buffer solutions [156]. Alsager et al. selected a 75-mer ssDNA MRE specific for E2 with a $K_{d}$ of $50 \mathrm{nM}$ after eighteen rounds of selection. The $5^{\prime}$ amino-modified MRE was covalently conjugated to carboxylated nanoparticles and dynamic light scattering/resistive pulse sensing was used to observe size contraction in particle size upon E2 binding. A detection range of $5 \mathrm{nM}$ to $100 \mathrm{nM}$ was achieved with this detection platform. Progesterone, testosterone, Bis (4-hydroxyphenyl) methane (BPF), and bisphenol-A (BPA) were also tested for the specificity of the selected MRE. The assay showed minimal binding to both BPA and BPF; however, the MRE was not able to distinguish the other two steroids [157].

Bisphenol A (BPA) is an estrogen mimicking chemical that has been classified as an endocrine-disrupting compound. It is used in the manufacture of polycarbonate plastic products, such as plastic bottles and containers. It has been shown to be released into food after heating and can accumulate in human [259]. Jo et al. selected ssDNA MRE specific for Bisphenol A with high affinity and specificity. The reported $K_{d}$ was $8.3 \mathrm{nM}$ with only minimal binding to structurally related chemical molecules, including $6 \mathrm{~F}$ biophenol A, bisphenol B, and 4, 4' -bisphenol. A cy-3 labeled MRE pair was immobilized on sol-gel biochip and a sandwich 
detection assay was developed with nanomolar range sensitivity. However, the authors acknowledged the assay system can only detect a limited range of BPA concentrations [158].

Polychlorinated biphenyls (PCB) are a group of chlorinated hydrocarbons that are used in varies of industrial settings. PCBs are highly toxic and are reported to be an environmental contaminant affecting water bodies and food sources [260]. Mehta et al. identified PCB binding ssDNA MREs with nanomolar range affinity. In their study, two PCB compounds with hydroxyl functional group were immobilized on magnetic beads and used as target for selection. After nine rounds of selection, three candidate sequences were chosen for characterization. Two of the three candidate sequences (9.1 and 9.3) showed comparable binding affinities to both immobilized targets. In subsequent crossingbinding analysis, candidate 9.1 showed broad substrate binding affinity to other PCB compounds, while candidate 9.2 showed a high specificity for the two PCBs with hydroxyl functional groups. The study did not test specificity on other hydrocarbons that are structurally similar to PCB [160]. Xu et al. immobilized a primary amine modified PCB compound $\left(\mathrm{PCB} 77-\mathrm{NH}_{2}\right)$ on epoxy-activated Sepharose agarose as the target for in vitro selection. After 11 rounds of selection, four candidate sequences were characterized to have affinity in the low micromolar range. Cross-binding assays showed only minimal binding toward other hydrocarbons and agarose substrate. A fluorescent based detection assay was developed using the fluorescence quenching property of gold nanoparticle. Upon binding to target, the fluorescent signal was released. A detection range of $0.1-100 \mathrm{ng} / \mathrm{mL}$ was achieved. This assay detected other PCB compounds with different sensitivities [159].

The current detection method for herbicides and pesticides environmental contaminants in the environment relies on using time-consuming and labor intensive laboratory based equipment. MREs have been investigated as binding elements in rapid, field deployable detection systems. Atrazine is a widely used herbicide worldwide [261]. Sanchez utilized CE-SELEX to identify ssDNA MRE specific for atrazine with a $K_{d}$ of $890 \mathrm{nM}$. However, the MRE did not show specificity in binding between atrazine and structurally closely related simazine at concentration below approximately $2 \mu \mathrm{M}$ in a fluorescence polarization detection assay [161].

Williams et al. also performed an in vitro selection of ssDNA MRE specific for atrazine. A derivative of atrazine, desethyl-atrazine was first biotinylated and then immobilized on streptavidin coated magnetic beads. The selection scheme was designed with increasing selection stringency, by incorporating negative selections on streptavidin magnetic beads, simazine, metabolites of atrazine, and other commonly used pesticides. Competition selection was also performed to ensure the library bound only to free atrazine in solution, but not to desethyl atrazine. As a result, ssDNA MRE with subnanomolar affinity and high specificity was identified after twelve rounds of selection. A magnetic bead based capture assay coupled with capillary electrophoresis was developed to detect atrazine in artificially contaminated river water samples. The assay was able to detect atrazine in the nanomolar range [14]. Similar in vitro selection methodology was also employed by Williams et al. to identify MREs specific for a commonly used organophosphate pesticide, malathion. In their second selection, the selected MRE had high nanomolar range affinity, and minimal binding to metabolites of malathion and other herbicides. However, the author noted that the cross-binding activity was high on bovine serum albumin possibility due to the large, globular characteristics of the protein [15]. William et al. subsequently performed another selection on an herbicide, bromacil. This study further validated the methodology the authors employed to identify MREs with high affinity and low cross-binding activities on structurally similar compounds and compounds that were likely to coexist in the environment. The authors noted that these properties were particularly important for incorporating ssDNA MREs as sensing elements in biosensors [16].

As noted above, not every chemical toxin can be readily immobilized for portioning during selection. In order to circumvent this limitation, Wang et al. utilized an immobilization free in vitro SELEX developed by Li and coworkers to select ssDNA MREs specific for four different organophosphorus pesticides, phorate, profenofos, isocarbophos, and omethoate $[26,28]$. After twelve rounds of selection, two candidate sequences reported $K_{d}$ values in the low micromolar range for all four targets. Cross-binding assays showed good specificities for the selected two MREs, with only minimal observed binding to eight other different pesticides [28]. The same group of researchers later developed a fluorescence polarization assay using the selected MREs to detect phorate, profenofos, isocarbophos, and omethoate at a LOD of 19.2, 13.4, 17.2, and 23.4 $\mathrm{nM}$, respectively [247].

He et al. employed immobilization-free SELEX to identify ssDNA MRE specific for pesticide, acetamiprid. After eighteen rounds of selection, the best candidate MRE was reported to have a $K_{d}$ of $4.96 \mu \mathrm{M}$. Specificity of the selected MRE was tested and cross-binding data showed no significant change in fluorescent signals in the presence of three other pesticides, imidacloprid, nitenpyram, and chlorpyrifos. The authors noted that the affinity of the selected MRE was lower than typical antibodies [27].

GO-SELEX was used to identify three ssDNA MREs specific to three different pesticides: tebuconazole, mefenacet, and inabenfide [25]. The reported values of $K_{d}$ were in the range of 10 to $100 \mathrm{nM}$. High specificity of each identified MRE was also determined by isothermal titration calorimetric and gold nanoparticle colorimetric assays. A simple, rapid detection method using gold nanoparticles was developed with LOD ranges from 100 to $400 \mathrm{nM}$.

\section{General Classes of Detection Methods}

In recent years, a large number of researches have taken place in applying ssDNA MREs for the use in biosensors. Major detection methods can be categorized into three classes: (1) electrical/electrochemical, (2) optical, and (3) mass sensitive. The following section highlights the basic principles of the general classes of detection methods that have been utilized 
TABLE 6: Summary table of ssDNA MRE based biosensors for the detection of pathogens.

\begin{tabular}{|c|c|c|c|c|c|}
\hline Target & Detection methods & Enhancers & LOD & $\begin{array}{l}\text { Relevant } \\
\text { sample }\end{array}$ & Reference \\
\hline Salmonella enteritidis & Fluorescence & Graphene oxide & $40 \mathrm{CFU} / \mathrm{mL}$ & Milk & {$[162]$} \\
\hline Salmonella enteritidis & $\begin{array}{l}\text { Colorimetric } \\
\text { lateral flow }\end{array}$ & Gold nanoparticles & $10 \mathrm{CFU} / \mathrm{mL}$ & Milk powder & {$[163]$} \\
\hline Salmonella Typhimurium & Colorimetric & Silver staining & $7 \mathrm{CFU} / \mathrm{mL}$ & Lake water & {$[164]$} \\
\hline Salmonella Typhimurium & $\begin{array}{l}\text { Electrochemical } \\
\text { impedance }\end{array}$ & $\begin{array}{l}\text { Graphene oxide, gold } \\
\text { nanoparticles }\end{array}$ & $3 \mathrm{CFU} / \mathrm{mL}$ & Pork & {$[165]$} \\
\hline Salmonella Typhimurium & $\begin{array}{l}\text { Electrochemical } \\
\text { impedance }\end{array}$ & Gold nanoparticles & $600 \mathrm{CFU} / \mathrm{mL}$ & - & {$[166]$} \\
\hline Salmonella Typhimurium & $\begin{array}{l}\text { Colorimetric } \\
\text { enzyme linked assay }\end{array}$ & Gold nanoparticles & $1000 \mathrm{CFU} / \mathrm{mL}$ & Milk & {$[167]$} \\
\hline $\begin{array}{l}\text { Vibrio } \\
\text { parahaemolyticus/Salmonella } \\
\text { Typhimurium }\end{array}$ & $\begin{array}{l}\text { Fluorescence } \\
\text { flow cytometry }\end{array}$ & Quantum dots & $5000 \mathrm{CFU} / \mathrm{mL}$ & Shrimp & [168] \\
\hline $\begin{array}{l}\text { Salmonella } \\
\text { Typhimurium/Staphylococcus } \\
\text { aureus }\end{array}$ & Fluorescence & - & $\begin{array}{l}5 \mathrm{CFU} / \mathrm{mL} \\
8 \mathrm{CFU} / \mathrm{mL}\end{array}$ & - & [169] \\
\hline Staphylococcus aureus & $\begin{array}{l}\text { Electrochemical } \\
\text { impedance }\end{array}$ & $\begin{array}{l}\text { Single-walled carbon } \\
\text { nanotubes }\end{array}$ & $800 \mathrm{CFU} / \mathrm{mL}$ & Pig skin & {$[170]$} \\
\hline Staphylococcus aureus & $\begin{array}{l}\text { Electrochemical } \\
\text { impedance }\end{array}$ & Graphene oxide & $1 \mathrm{CFU} / \mathrm{mL}$ & - & {$[171]$} \\
\hline Staphylococcus aureus & Colorimetric & Horseradish peroxidase & $9 \mathrm{CFU} / \mathrm{mL}$ & Milk & {$[172]$} \\
\hline Group A Streptococcus & Piezoelectric quartz crystal & $\begin{array}{l}\text { Single-walled carbon } \\
\text { nanotubes }\end{array}$ & $12 \mathrm{CFU} / \mathrm{mL}$ & Milk & {$[173]$} \\
\hline E. coli & Electrochemical/fluorescence & MRE cocktails & $370 \mathrm{CFU} / \mathrm{mL}$ & - & {$[174]$} \\
\hline $\begin{array}{l}\text { E. coli O157:H7/Salmonella } \\
\text { Typhimurium }\end{array}$ & Colorimetric & - & $10000 \mathrm{CFU} / \mathrm{mL}$ & - & {$[175]$} \\
\hline E. coli O111 & $\begin{array}{l}\text { Electrochemical } \\
\text { redox current }\end{array}$ & Alkaline phosphatase & $305 \mathrm{CFU} / \mathrm{mL}$ & Milk & {$[176]$} \\
\hline E. coli CECT 675 & $\begin{array}{l}\text { Electrochemical } \\
\text { impedance }\end{array}$ & $\begin{array}{l}\text { Single-walled carbon } \\
\text { nanotubes }\end{array}$ & $\begin{array}{l}6 \mathrm{CFU} / \mathrm{mL} \\
26 \mathrm{CFU} / \mathrm{mL}\end{array}$ & $\begin{array}{l}\text { Milk, apple } \\
\text { juice }\end{array}$ & {$[177]$} \\
\hline Pseudomonas aeruginosa & Fluorescence & - & $5 \mathrm{CFU} / \mathrm{mL}$ & Drinking water & {$[178]$} \\
\hline $\begin{array}{l}\text { Staphylococcus aureus/Vibrio } \\
\text { parahaemolyticus/Salmonella } \\
\text { Typhimurium }\end{array}$ & Luminescence & $\begin{array}{l}\text { Lanthanide-doped near } \\
\text { infrared to visible } \\
\text { upconversion } \\
\text { nanoparticles }\end{array}$ & $\begin{array}{l}25 \mathrm{CFU} / \mathrm{mL} \\
10 \mathrm{CFU} / \mathrm{mL} \\
15 \mathrm{CFU} / \mathrm{mL}\end{array}$ & Milk, shrimp & [179] \\
\hline $\begin{array}{l}\text { Lactobacillus } \\
\text { acidophilus/Staphylococcus } \\
\text { enteric/Staphylococcus aureus }\end{array}$ & $\begin{array}{l}\text { Fluorescence } \\
\text { microfluidic biochip }\end{array}$ & - & $\begin{array}{l}11 \mathrm{CFU} / \mathrm{mL} \\
61 \mathrm{CFU} / \mathrm{mL} \\
800 \mathrm{CFU} / \mathrm{mL}\end{array}$ & - & {$[180]$} \\
\hline Influenza H5N1 & Quartz crystal microbalance & Hydrogel & $0.0128 \mathrm{HAU}$ & - & {$[181]$} \\
\hline Vaccinia virus & $\begin{array}{l}\text { Electrochemical } \\
\text { impedance }\end{array}$ & - & 60 virions $/ \mu \mathrm{L}$ & - & {$[182]$} \\
\hline Influenza H5N1 & Surface plasmon resonance & - & $0.128 \mathrm{HAU}$ & Poultry & {$[183]$} \\
\hline
\end{tabular}

widely in the development of ssDNA MRE based biosensors. The relative portability of different detection methods is also briefly discussed. Recent literatures describing the detection of pathogens and toxins using ssDNA MREs biosensors are summarized in Tables 6, 7, and 8 .

3.1. Electrical/Electrochemical. The principle of electrochemical detection is based on measuring changes in electrical properties of the sensing platform. In this method, ssDNA
MRE is usually immobilized on a gold electrode via thiol-gold linkage. A redox label, such as methylene blue, can be used to detect binding between MRE and the target [262]. In a "signal on" system, the redox label is away from the electrode surface, and the binding of target causes a conformational change in the MRE and brings the redox label into close proximity with the electrode, thus causing a measurable change in electrical properties (Figure 2). A "signal off" system behaves similarly, but the binding of target causes the redox label to move 
TABLE 7: Summary table of ssDNA MRE based biosensors for the detection of biological toxins.

\begin{tabular}{|c|c|c|c|c|c|}
\hline Target & Detection methods & Enhancers & LOD & $\begin{array}{l}\text { Relevant } \\
\text { sample }\end{array}$ & Reference \\
\hline Prion protein & Resonance light scattering & Gold nanoparticles & $0.01 \mathrm{nM}$ & Human serum & {$[184]$} \\
\hline $\begin{array}{l}\text { Clostridium difficile } \\
\text { Toxin A }\end{array}$ & $\begin{array}{l}\text { Electrochemical } \\
\text { impedance }\end{array}$ & Horseradish peroxidase & $1 \mathrm{nM}$ & - & {$[185]$} \\
\hline $\begin{array}{l}\text { Staphylococcal } \\
\text { enterotoxin B }\end{array}$ & $\begin{array}{l}\text { Electrochemical } \\
\text { impedance }\end{array}$ & Horseradish peroxidase & $0.24 \mathrm{ng} / \mathrm{mL}$ & Human serum & {$[186]$} \\
\hline $\begin{array}{l}\text { Staphylococcal } \\
\text { enterotoxin B }\end{array}$ & $\begin{array}{l}\text { Surface-enhanced Raman } \\
\text { scattering }\end{array}$ & Gold nanoparticles & $224 \mathrm{aM}$ & $\begin{array}{l}\text { Milk, blood, } \\
\text { urine }\end{array}$ & {$[187]$} \\
\hline $\begin{array}{l}\text { Staphylococcal } \\
\text { enterotoxin B }\end{array}$ & $\begin{array}{l}\text { Piezoresistive } \\
\text { microcantilevers }\end{array}$ & - & $6 \mathrm{ng} / \mathrm{mL}$ & Skim milk & {$[188]$} \\
\hline $\begin{array}{l}\text { E. coli outer } \\
\text { membranes proteins }\end{array}$ & Evanescent wave fiber optic & - & $0.1 \mathrm{nM}$ & $\begin{array}{l}\text { Environmental } \\
\text { water }\end{array}$ & {$[189]$} \\
\hline $\begin{array}{l}\text { E. coli outer } \\
\text { membranes proteins }\end{array}$ & $\begin{array}{l}\text { Electrochemical } \\
\text { impedance }\end{array}$ & - & $100 \mathrm{nM}$ & $\begin{array}{l}\text { Environmental } \\
\text { water }\end{array}$ & {$[190]$} \\
\hline $\begin{array}{l}\text { Botulinum } \\
\text { neurotoxin, type A }\end{array}$ & $\begin{array}{l}\text { Electrochemical } \\
\text { redox current }\end{array}$ & Horseradish peroxidase & $40 \mathrm{pg} / \mathrm{mL}$ & - & {$[191]$} \\
\hline Aflatoxin B1 & RT-qPCR & - & $25 \mathrm{fg} / \mathrm{mL}$ & $\begin{array}{l}\text { Chinese wild } \\
\text { rye hay, infant } \\
\text { rice cereal }\end{array}$ & {$[192]$} \\
\hline Aflatoxin B1 & $\begin{array}{l}\text { Fluorescence } \\
\text { dipstick }\end{array}$ & - & $0.3 \mathrm{ng} / \mathrm{g}$ & Corn & {$[193]$} \\
\hline Aflatoxin M1 & $\begin{array}{l}\text { Electrochemical } \\
\text { redox current }\end{array}$ & Magnetic nanoparticles & $8 \mathrm{ng} / \mathrm{L}$ & Milk & {$[194]$} \\
\hline Ochratoxin A & Colorimetric & - & $20 \mathrm{nM}$ & - & {$[195]$} \\
\hline Ochratoxin A & $\begin{array}{l}\text { Electrochemical } \\
\text { impedance }\end{array}$ & $\begin{array}{l}\text { Graphene oxide, gold } \\
\text { nanoparticles }\end{array}$ & $0.74 \mathrm{pM}$ & Red wine & {$[196]$} \\
\hline Ochratoxin A & Fluorescence & - & $1 \mathrm{ng} / \mathrm{mL}$ & Beer & {$[197]$} \\
\hline Ochratoxin A & $\begin{array}{l}\text { Electrochemical } \\
\text { redox current }\end{array}$ & Gold nanoparticles & $0.75 \mathrm{pM}$ & Red wine & {$[198]$} \\
\hline Ochratoxin A & Electrochemiluminescence & $\begin{array}{l}\text { Loop-mediated isothermal } \\
\text { amplification }\end{array}$ & $10 \mathrm{fM}$ & Red wine & [199] \\
\hline Ochratoxin A & Fluorescence & - & $2 \mathrm{pg} / \mathrm{mL}$ & Wheat & {$[200]$} \\
\hline Ochratoxin A & $\begin{array}{l}\text { Localized surface plasmon } \\
\text { resonance }\end{array}$ & - & $1 \mathrm{nM}$ & Corn powder & {$[201]$} \\
\hline Ochratoxin A & RT-qPCR & - & $1 \mathrm{fg} / \mathrm{mL}$ & Red wine & {$[202]$} \\
\hline Ochratoxin A & Fluorescence & - & $0.2 \mathrm{ng} / \mathrm{mL}$ & Red wine & [203] \\
\hline Ochratoxin A & Chemiluminescence & Nicking endonuclease & $0.3 \mathrm{pg} / \mathrm{mL}$ & Wheat & [204] \\
\hline Ochratoxin A & $\begin{array}{l}\text { Electrochemical } \\
\text { impedance }\end{array}$ & - & $0.25 \mathrm{ng} / \mathrm{mL}$ & Beer & {$[205]$} \\
\hline Ochratoxin A & $\begin{array}{l}\text { Electrochemical } \\
\text { redox current }\end{array}$ & - & $0.1 \mathrm{ng} / \mathrm{mL}$ & Beer & {$[206]$} \\
\hline Ochratoxin A & $\begin{array}{l}\text { Electrochemical } \\
\text { impedance }\end{array}$ & - & $0.12 \mathrm{ng} / \mathrm{mL}$ & Beer & {$[207]$} \\
\hline Ochratoxin A & $\begin{array}{l}\text { Electrochemical } \\
\text { differential pulse } \\
\text { voltammetry }\end{array}$ & $\begin{array}{l}\text { Horseradish peroxidase, } \\
\text { alkaline phosphatase, } \\
\text { superparamagnetic } \\
\text { nanoparticles }\end{array}$ & $0.15 \mathrm{ng} / \mathrm{mL}$ & Red wine & {$[208]$} \\
\hline Ochratoxin A & $\begin{array}{l}\text { Electrochemical } \\
\text { flow-based }\end{array}$ & - & $0.05 \mu \mathrm{g} / \mathrm{L}$ & Beer & [209] \\
\hline Ochratoxin A & $\begin{array}{l}\text { Colorimetric } \\
\text { lateral flow }\end{array}$ & Gold nanoparticles & $1 \mathrm{ng} / \mathrm{mL}, 0.18 \mathrm{ng} / \mathrm{mL}$ & Red wine & {$[210]$} \\
\hline
\end{tabular}


TABLe 7: Continued.

\begin{tabular}{|c|c|c|c|c|c|}
\hline Target & Detection methods & Enhancers & LOD & $\begin{array}{l}\text { Relevant } \\
\text { sample }\end{array}$ & Reference \\
\hline Ochratoxin A & $\begin{array}{l}\text { Fluorescence } \\
\text { lateral flow }\end{array}$ & Quantum dots & $1.9 \mathrm{ng} / \mathrm{mL}$ & Red wine & {$[211]$} \\
\hline Ochratoxin A & $\begin{array}{l}\text { Electrochemical } \\
\text { electric current }\end{array}$ & Horseradish peroxidase & $0.07 \pm 0.01 \mathrm{ng} / \mathrm{mL}$ & Wheat & [212] \\
\hline Ochratoxin A & $\begin{array}{l}\text { Electrochemical } \\
\text { redox current }\end{array}$ & Gold nanoparticles & $30 \mathrm{pg} / \mathrm{mL}$ & Red wine & {$[213]$} \\
\hline Ochratoxin A & $\begin{array}{l}\text { Electrochemical } \\
\text { impedance }\end{array}$ & Horseradish peroxidase & $0.4 \mathrm{pg} / \mathrm{mL}$ & Wheat & {$[214]$} \\
\hline Ochratoxin A & $\begin{array}{l}\text { Electrochemical } \\
\text { redox current }\end{array}$ & - & $0.095 \mathrm{pg} / \mathrm{mL}$ & Red wine & {$[215]$} \\
\hline Ochratoxin A & Chemiluminescence & Upconversion nanoparticles & $0.1 \mathrm{pg} / \mathrm{mL}$ & Maize & {$[216]$} \\
\hline Ochratoxin A & $\begin{array}{l}\text { Electrochemical } \\
\text { impedance }\end{array}$ & Silver nanoparticles & $0.05 \mathrm{nM}$ & Beer & {$[217]$} \\
\hline Ochratoxin A & $\begin{array}{l}\text { Electrochemical } \\
\text { impedance }\end{array}$ & Loop-mediated isothermal & $0.3 \mathrm{pM}$ & Red wine & {$[218]$} \\
\hline Ochratoxin A & Fluorescence & - & $0.8 \mathrm{ng} / \mathrm{mL}$ & Corn & {$[219]$} \\
\hline Ochratoxin A & Fluorescence & Single-stranded signal probes & $20 \mathrm{pg} / \mathrm{mL}$ & Wheat & {$[220]$} \\
\hline Ochratoxin A & Fluorescence & Terbium & $0.08-5.42 \mathrm{ng} / \mathrm{mL}$ & Wheat & {$[221]$} \\
\hline Ochratoxin A & $\begin{array}{l}\text { Electrochemical } \\
\text { impedance }\end{array}$ & Redox probe & $0.12-0.4 \mathrm{nM}$ & $\begin{array}{l}\text { Coffee, flour, } \\
\text { wine }\end{array}$ & {$[222]$} \\
\hline Ochratoxin A & $\begin{array}{l}\text { Fluorescence resonance } \\
\text { energy transfer }\end{array}$ & - & $2 \mathrm{pg} / \mathrm{mL}$ & Maize flour & {$[223]$} \\
\hline Ochratoxin A & $\begin{array}{l}\text { Electrochemical } \\
\text { redox current }\end{array}$ & Exonuclease digestion & $1.0 \mathrm{pg} / \mathrm{mL}$ & Wheat starch & {$[224]$} \\
\hline Ochratoxin A & $\begin{array}{l}\text { Electrochemical } \\
\text { electric current }\end{array}$ & Rolling circle amplification & $0.2 \mathrm{pg} / \mathrm{mL}$ & Red wine & {$[225]$} \\
\hline Ochratoxin A & Fluorescence & - & $21.8 \mathrm{nM}$ & Red wine & {$[226]$} \\
\hline Ochratoxin A & Electrochemiluminescence & Gold nanoparticles & $0.007 \mathrm{ng} / \mathrm{mL}$ & Wheat & {$[227]$} \\
\hline Ochratoxin A & Colorimetric & - & $2.5 \mathrm{nM}$ & Red wine & {$[228]$} \\
\hline Ochratoxin A & Colorimetric & - & $4 \mathrm{nM}$ & Red wine & {$[229]$} \\
\hline Ochratoxin A & Fluorescence & - & $24.1 \mathrm{nM}$ & Beer & {$[230]$} \\
\hline Ochratoxin A & $\begin{array}{l}\text { Electrochemical } \\
\text { impedance }\end{array}$ & - & $0.1 \mathrm{ng} / \mathrm{mL}$ & - & {$[231]$} \\
\hline Ochratoxin A & Fluorescence & - & $0.01 \mathrm{ng} / \mathrm{mL}$ & Maize flour & {$[232]$} \\
\hline
\end{tabular}

away from the electrode. This system can also be modified as a "label-free" system, in which the redox molecule is intercalated in a hairpin structure of a MRE in a target unbound state, and binding of the target causes the release of the redox molecule (Figure 2). In addition to measuring redox current, the changes in impedance upon binding of the target can also be measured. In this case, no labeling of MRE is required and the conformational changes in MRE upon target binding cause a measurable change in impedance that can be recorded by voltammetry [212].

Nanomaterials can also be incorporated into electrochemical sensor to enhance signals. Single-walled carbon nanotube field effect transistors (SWCNT-FET) can be used to build electrochemical biosensors (Figure 3). In this system, MREs are immobilized on SWCNTs and SWCNTs are sandwiched between a source and a drain electrode. When the immobilized MREs bind to the target, there is a measurable change in the conductance of the system [240]. Gold nanoparticles (AuNP) are also widely used as signal enhancers. AuNPs can be coated on electrodes and greatly increase the surface area. As a result, more MREs can be immobilized on the electrode, thus enhancing the system's sensitivity. AuNPs can also be coated with a second MRE and reporting probes in a sandwich assay (Figure 3). In this case, the target first binds to a primary capturing MRE, followed by the binding a secondary reporting MRE along with a redox molecule, which can generate an enhanced signal for sensitive detection [263].

In general, electrical/electrochemical detection systems are relatively smaller and more easily adapted into portable, chip-based platforms. This allows the ssDNA MREs biosensors to be used for on-site target detection [211, 212]. 
TABLE 8: Summary table of ssDNA MREs based biosensors for the detection of chemical toxins.

\begin{tabular}{|c|c|c|c|c|c|}
\hline Target & Detection methods & Enhancers & LOD & Relevant sample & Reference \\
\hline Bisphenol A & Fiber optic fluorescence & - & $1.86 \mathrm{nM}$ & Waste water & [233] \\
\hline Bisphenol A & Resonance light scattering & Gold nanoparticles & $0.012-0.28 \mathrm{ng} / \mathrm{mL}$ & Supermarket ticket & {$[234]$} \\
\hline Bisphenol A & $\begin{array}{l}\text { Electrochemical } \\
\text { redox current }\end{array}$ & $\begin{array}{l}\text { Gold nanoparticles } \\
\text { dotted graphene }\end{array}$ & $5 \mathrm{nM}$ & Milk & {$[235]$} \\
\hline Bisphenol A & Colorimetric/fluorescent & - & $\begin{array}{c}0.1 \mathrm{ng} / \mathrm{mL} \\
0.01 \mathrm{pg} / \mathrm{mL}\end{array}$ & Water & {$[236]$} \\
\hline Bisphenol A & Colorimetric & - & $0.1 \mathrm{ng} / \mathrm{mL}$ & Tap water & {$[237]$} \\
\hline Bisphenol A & $\begin{array}{l}\text { Colorimetric } \\
\text { lateral flow }\end{array}$ & Gold nanoparticles & $76 \mathrm{pg} / \mathrm{mL}$ & Tap water & {$[238]$} \\
\hline Bisphenol A & $\begin{array}{l}\text { Resonance Rayleigh } \\
\text { scattering }\end{array}$ & Gold nanoparticles & $83 \mathrm{pg} / \mathrm{mL}$ & Tap water & {$[239]$} \\
\hline Bisphenol A & $\begin{array}{l}\text { Electrochemical } \\
\text { electric current }\end{array}$ & $\begin{array}{l}\text { Single-walled carbon } \\
\text { nanotubes field effect } \\
\text { transistor }\end{array}$ & $10 \mathrm{fM}$ to $1 \mathrm{pM}$ & & {$[240]$} \\
\hline Bisphenol A & Plasmonic chirality & - & $8 \mathrm{pg} / \mathrm{mL}$ & Tap water & {$[241]$} \\
\hline $17 \beta$-estradiol (E2) & Photoelectrochemical & $\begin{array}{l}\text { Titanium oxide } \\
\text { nanotubes arrays }\end{array}$ & $33 \mathrm{fM}$ & $\begin{array}{l}\text { Medical waste water, } \\
\text { lake water, and tap } \\
\text { water }\end{array}$ & {$[242]$} \\
\hline $17 \beta$-estradiol (E2) & $\begin{array}{l}\text { Electrochemical } \\
\text { impedance }\end{array}$ & - & $2.0 \mathrm{pM}$ & Human urine & {$[243]$} \\
\hline $17 \beta$-estradiol (E2) & Fluorescence & - & $2.1 \mathrm{nM}$ & Waste water & {$[244]$} \\
\hline Acetamiprid & Colorimetric & - & $5 \mathrm{nM}$ & Soil & [245] \\
\hline Acetamiprid & $\begin{array}{l}\text { Electrochemical } \\
\text { impedance }\end{array}$ & Gold nanoparticles & $1 \mathrm{nM}$ & $\begin{array}{l}\text { Waste water, } \\
\text { tomatoes }\end{array}$ & {$[246]$} \\
\hline $\begin{array}{l}4 \text { organophosphorus } \\
\text { pesticides } \\
\text { phorate, profenofos, } \\
\text { isocarbophos, and } \\
\text { omethoate }\end{array}$ & Fluorescence polarization & - & $\begin{array}{c}19.2,13.4,17.2 \\
23.4 \mathrm{nM}\end{array}$ & Chinese cabbage & {$[247]$} \\
\hline
\end{tabular}

3.2. Optical. Optical detection methods can be classified into three major categories: (1) fluorescence detection, which require specialized instruments to measure fluorescent signals; (2) colorimetric detection, which color changes can be observed by the naked eye or measured in terms of optical density; (3) absorbance assay can enhance detection signals, and subsequently be measured by instruments as well.

3.2.1. Fluorescence. The principle of fluorescence detection is based on the generation or quenching of fluorescence signals upon target binding. Various fluorescence molecules and quantum dots can be linked to ssDNA MREs. Conformational changes induced by target binding can alter the fluorescence signal generated by the fluorophore and therefore can be measured (Figure 4) [264]. Quenching molecules can also be linked to the other end of the ssDNA MRE. In this system, the quencher completely blocks the fluorescence signal from the fluorophore and target binding can move the quencher away from the fluorophore and have "signal on" detection (Figure 4) [265]. The same principle can also be applied for a "signal off" system. Carbon nanotubes and graphene can also be used as quenchers, where fluorescent labeled ssDNA MREs is adsorbed on the carbon quenchers via $\pi-\pi$ stacking interactions. Fluorescence resonance energy transfer (FRET) can also be utilized as measurements when the distance of the two fluorescence molecules linked to MREs is changed upon target binding.

Fluorescence based detection systems are frequently developed because of their high sensitivity and the ease of fluorescently labeling ssDNA MREs. Traditionally, the complete detection system requires large, costly components, including lasers, filters, and detectors. A recent study reported a portable ssDNA MRE based biosensor utilizing an optic fiber for sensitive detection of BPA [233].

3.2.2. Colorimetric. Gold nanoparticles (AuNP) have been widely used in various colorimetric assays. AuNPs aggregate in salt solution and appear in purple color. When they are dispersed, they are in red color. This special absorbance property of AuNPs allows observation of target binding by naked eye. MREs in salt solution can bind to AuNPs, dispersing the AuNPs. When targets are introduced into the system, MRE preferably bind to the targets, therefore causing AuNPs to aggregate, and a red to purple color change is observed (Figure 5) [266]. Alternatively, ssDNA MREs can be used to link AuNPs that are functionalized with probe 


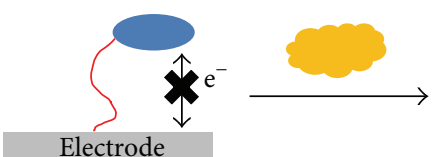

(a)

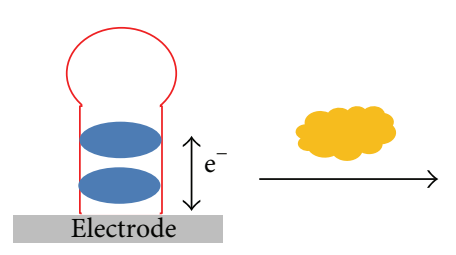

(b)

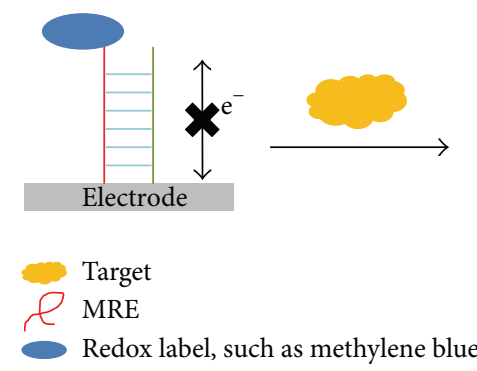

(c)

FIGURE 2: Illustration of examples of ssDNA MRE based electrochemical biosensors. (a) A representation of an "on-mode" system using a redox label for current transduction. (b) A representation of a "label-free" system by intercalating a redox label in a hairpin structure. (c) A representation of an "on-mode" system by hybridization with the complementary sequence.

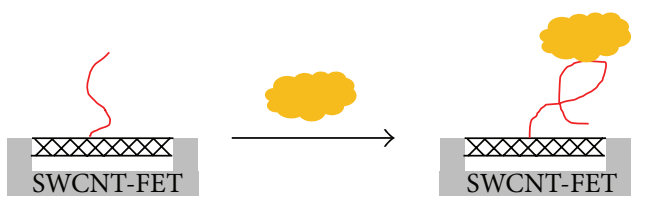

(a)

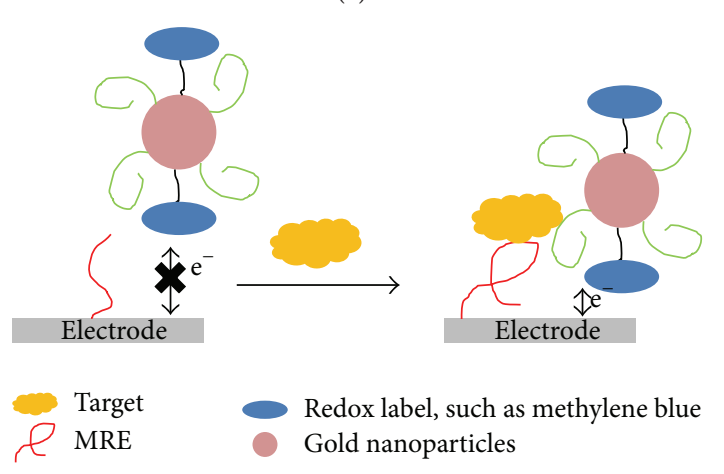

(b)

FIGURE 3: Illustration of examples of signal enhancement methods in ssDNA MRE based electrochemical biosensors. (a) A representation of a single-walled carbon nanotubes field effect transistors. (b) A representation of gold nanoparticles carrying redox labels in a sandwich detection style.
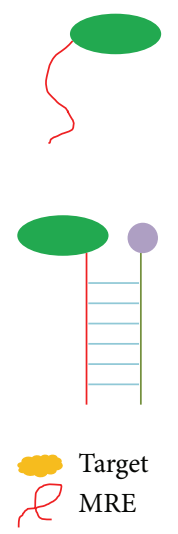

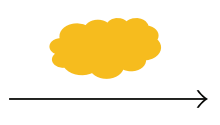

(a)

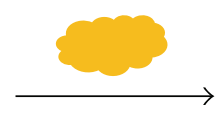

Fluorophore, such as FAM, FITC

Quencher

(b)
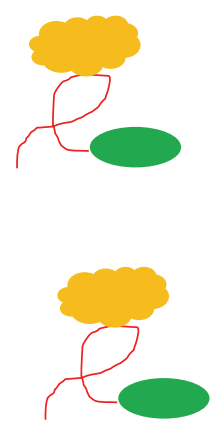$$
\text { TC }
$$

FIGURE 4: Illustration of examples of ssDNA MRE based fluorescent biosensors. (a) A representation of the changes in fluorescent signal upon target binding to a fluorophore labeled MRE. (b) A representation of an "on-mode" system by using a quencher labeled on the complementary sequence.

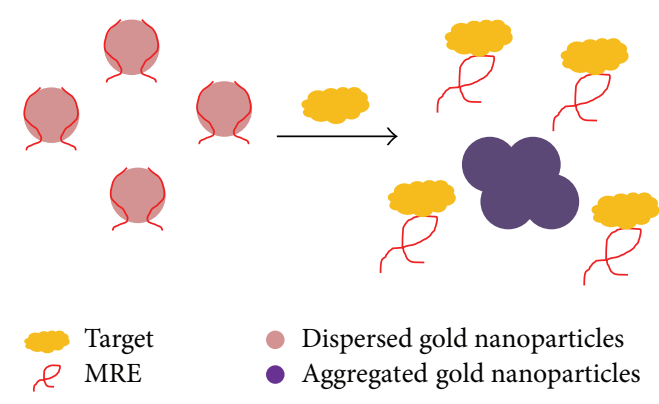

(a)

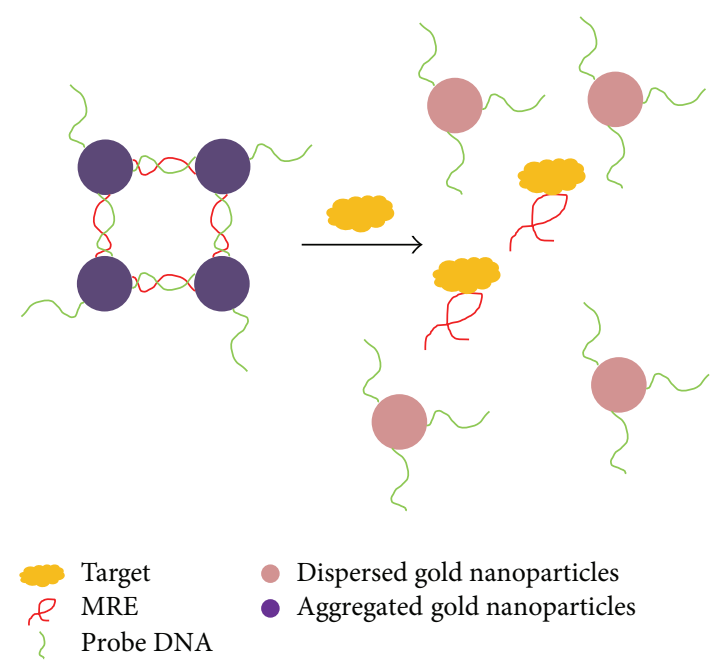

(b)
FIGURE 5: Illustration of examples of ssDNA MRE based colorimetric biosensors. (a) A representation of a colorimetric assay using MRE dispersed gold nanoparticles. (b) A representation of a colorimetric assay using cross-linked gold nanoparticles aggregates via MRE and probe DNA. 


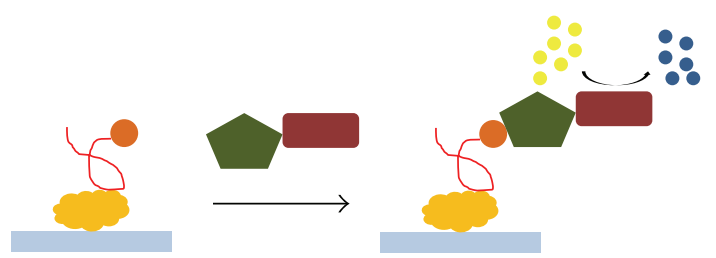

(a)

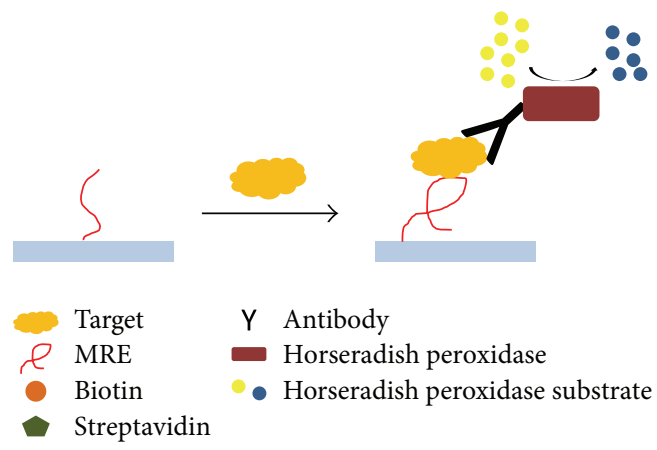

(b)

FIGURE 6: Illustration of examples of ssDNA MRE modified enzyme linked assays. (a) A representation of a direct MREs modified enzyme linked assay with MRE as the reporter. (b) A representation of an indirect MREs modified enzyme linked assay with MRE as the target capturing element.

strands. In this case, the initial state of the MRE/AuNPs solution is aggregated purple. Upon target binding, the linked AuNPs are released, and a purple to red color change is observed (Figure 5) [267]. Furthermore, AuNPs can be used in a sandwich colorimetric assay, in which the secondary reporting MRE linked AuNP can grow in size when the detection system is placed in a growth solution containing $\mathrm{HAuCl}_{4}$, thus enhancing the detection limit [268].

Colorimetric detection systems are attractive for onsite target sensing due to the ease of observation with the naked eye. These systems are often developed into hand-held laminar flow devices [163, 204, 226].

3.2.3. Absorbance. Nucleic acid MREs have been used in modified enzyme linked immunoassays, usually substituting for either the capturing or the reporter antibodies. In a direct oligonucleotide enzyme link assay, often the protein target is adsorbed on plate and biotinylated MREs bind to the target and then followed by the addition of streptavidin-horse radish peroxidase (HRP) conjugate and enzyme substrate for signal development [148]. In a sandwich assay, biotinylated MREs can be immobilized on streptavidin plate and then followed by the addition of the protein target, HRP linked antibody, and enzyme substrate [98]. This detection method is mostly limited to clinical laboratory settings and detection of protein targets for which antibodies have been isolated (Figure 6).

3.2.4. Mass Sensitive. Mass sensitive detection is a class of label-free detection system that can be subdivided into four

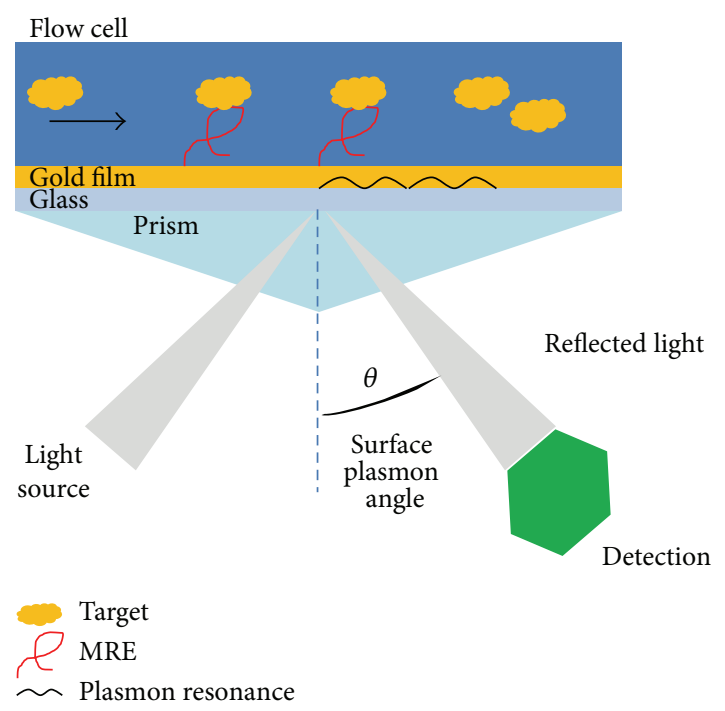

FIgURE 7: Illustration of ssDNA MRE based surface plasmon resonance biosensors. When targets bind to immobilized MREs, a change in the plasmon resonance and plasmon angle will be detected and translated into a real-time response unit.

major categories: (1) surface plasmon resonance (SPR), (2) quartz crystal microbalance (QCM), (3) surface acoustic wave (SAW), and (4) micromechanical cantilever. None of these detection systems require additional labeling.

Surface plasmon resonance (SPR) sensors measure a change in the refractive index and resonance angle when a mass change occurs upon target binding. MREs are often biotin-tagged and immobilized on streptavidin coated gold chip. When targets in solution pass through the flow cell, the binding between targets and immobilized MREs cause a change in mass on the sensor chip surface and is subsequently translated into a change in the refractive index. This change in resonance is proportional to the amount of target bound to the immobilized MREs and therefore providing a realtime detection of the target in solution (Figure 7) [183]. Commercially available SPR systems are typically large and limited to bench top use. One study reported a portable SPR biosensor based on ssDNA MREs for the detection of H5N1 influenza virus [183].

A Quartz crystal microbalance (QCM) is an acoustic wave resonator based on the piezoelectric property of quartz crystal. Nucleic acid MREs can be immobilized on goldcoated quartz. The binding between target and MRE increases the mass on the surface of the crystal and leads to a detectable decrease in the resonance frequency of the crystal (Figure 8) [181]. The detection principle of surface acoustic wave (SAW) based biosensor is similar to QCM. Nucleic acid MREs have been utilized to fabricate a special type of Love-wave sensor that uses shear horizontal waves to enhance the surface sensitivity and achieve ultrasensitive detection of the target [269].

Micromechanical cantilevers have been investigated for MRE based biosensors. The major advantage of this type of sensor is that it can be readily scale up and perform parallel analysis for multiple analytes with low background 

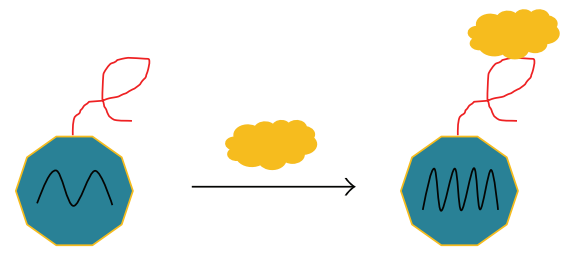

(a)

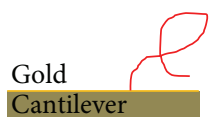

Target

MRE
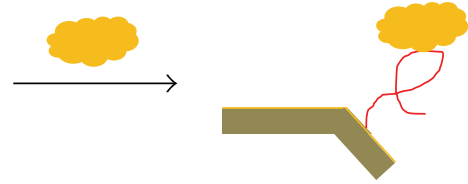

Gold coated quartz $M$ Resonance frequency

(b)

FIGURE 8: Illustration of examples of ssDNA MRE based mass sensitive biosensors. (a) A representation of a detectable change in resonance frequency upon target binding to immobilized MRE on quartz crystal microbalance. (b) Representation of a detectable nanometer scale bending upon target binding to immobilized MRE on micromechanical cantilever.

interference [270]. When the target binds to the MRE on the surface of the cantilever, a nanometer scale deflection in the cantilever can be detected optically (Figure 8). Zhao et al. reported the development of a ssDNA MRE based piezoresistive microcantilever biosensor for potential on-site detection of Staphylococcal enterotoxin B [188].

\section{Conclusions and Future Perspectives}

Over the last two decades, there has been a continuous increase in the research of molecular recognition elements. Single-stranded DNA MREs have several advantages over antibodies, in terms of stability, reusability, and production cost. However, ssDNA MREs are not without limitations. The binding affinity of MREs is highly dependent on their three-dimensional structure and is influenced by factors including the ionic condition, temperature, and $\mathrm{pH}$ of the binding condition [4]. Challenges remain in eliminating cross-binding activities to other molecules in native environments. These limitations hinder the use of MRE for detection in many real world complex samples, such as biological fluids and food matrices. A carefully designed selection scheme can greatly improve the specificity of the identified MRE, which can better distinguish closely related molecules at low concentrations. Using modified bases in PCR amplification or performing base modifications after selection can also help improving resistance to nucleases in many biological fluids, such as human serum [271].

As the field of ssDNA MRE based biosensors continues to grow, improvements in SELEX methodology will be necessary to more rapidly isolate MREs with the desired affinity and specificity. Improvements will also be necessary to allow MREs against more targets and a wider variety of targets to be isolated. The development of MRE based sensors is becoming an increasingly diverse field. Scientist and engineers from many disciplines must work together in order to create the optimal end product. Portable ssDNA MRE based biosensors may be utilized in a variety of settings, such as food safety, environmental monitoring, and health care. The many attractive features of ssDNA MREs prompt researchers to continue to investigate and optimize their applications in biosensing. The commercialization of these devices should continue to increase in the future.

\section{Conflict of Interests}

The authors declare that there is no conflict of interests regarding the publication of this paper.

\section{Acknowledgments}

This work was supported by the National Science Foundation Cooperative Agreements (NSF-1003907 and NSF-0554328), Department of Defense Cooperative Agreement (W911NF09-2-0044), and West Virginia University.

\section{References}

[1] C. Tuerk and L. Gold, "Systematic evolution of ligands by exponential enrichment: RNA ligands to bacteriophage T4 DNA polymerase," Science, vol. 249, no. 4968, pp. 505-510, 1990.

[2] S. D. Jayasena, "Aptamers: an emerging class of molecules that rival antibodies in diagnostics," Clinical Chemistry, vol. 45, no. 9, pp. 1628-1650, 1999.

[3] B. Hall, J. M. Micheletti, P. Satya, K. Ogle, J. Pollard, and A. D. Ellington, "Design, synthesis, and amplification of DNA pools for in vitro selection," in Current Protocols in Nucleic Acid Chemistry, chapter 9, unit 9.2, 2009.

[4] D. J. Patel, A. K. Suri, F. Jiang et al., "Structure, recognition and adaptive binding in RNA aptamer complexes," Journal of Molecular Biology, vol. 272, no. 5, pp. 645-664, 1997.

[5] A. S. R. Potty, K. Kourentzi, H. Fang, P. Schuck, and R. C. Willson, "Biophysical characterization of DNA and RNA aptamer interactions with hen egg lysozyme," International Journal of Biological Macromolecules, vol. 48, no. 3, pp. 392-397, 2011.

[6] N. De-los-Santos-Álvarez, M. J. Lobo-Castañón, A. J. MirandaOrdieres, and P. Tuñón-Blanco, "Modified-RNA aptamer-based sensor for competitive impedimetric assay of neomycin B," Journal of the American Chemical Society, vol. 129, no. 13, pp. 3808-3809, 2007.

[7] Y. Cui, H. Ulrich, and G. P. Hess, "Selection of $2^{\prime}$-fluoromodified RNA aptamers for alleviation of cocaine and MK801 inhibition of the nicotinic acetylcholine receptor," Journal of Membrane Biology, vol. 202, no. 3, pp. 137-149, 2004.

[8] K. M. You, S. H. Lee, A. Im, and S. B. Lee, "Aptamers as functional nucleic acids: in vitro selection and biotechnological applications," Biotechnology and Bioprocess Engineering, vol. 8, no. 2, pp. 64-75, 2003.

[9] L. S. Rotherham, C. Maserumule, K. Dheda, J. Theron, and M. Khati, "Selection and application of ssDNA aptamers to detect active TB from sputum samples," PLoS ONE, vol. 7, no. 10, Article ID e46862, 2012. 
[10] S.-J. Cho, H.-M. Woo, K.-S. Kim, J.-W. Oh, and Y.-J. Jeong, "Novel system for detecting SARS coronavirus nucleocapsid protein using an ssDNA aptamer," Journal of Bioscience and Bioengineering, vol. 112, no. 6, pp. 535-540, 2011.

[11] J. A. DeGrasse, "A single-stranded DNA aptamer that selectively binds to staphylococcus aureus enterotoxin B," PLOS ONE, vol. 7, no. 3, Article ID e33410, 2012.

[12] S. Eissa, A. Ng, M. Siaj, A. C. Tavares, and M. Zourob, "Selection and identification of DNA aptamers against okadaic acid for biosensing application," Analytical Chemistry, vol. 85, no. 24, pp. 11794-11801, 2013.

[13] M. McKeague, C. R. Bradley, A. de Girolamo, A. Visconti, J. David Miller, and M. C. de Rosa, "Screening and initial binding assessment of fumonisin $\mathrm{B}_{1}$ aptamers," International Journal of Molecular Sciences, vol. 11, no. 12, pp. 4864-4881, 2010.

[14] R. M. Williams, C. L. Crihfield, S. Gattu, L. A. Holland, and L. J. Sooter, "In vitro selection of a single-stranded DNA molecular recognition element against atrazine," International Journal of Molecular Sciences, vol. 15, no. 8, pp. 14332-14347, 2014.

[15] R. Williams, E. Maher, and L. Sooter, "In vitro selection of a single-stranded DNA molecular recognition element for the pesticide malathion," Combinatorial Chemistry \& High Throughput Screening, vol. 17, no. 8, pp. 694-702, 2014.

[16] R. M. Williams, A. R. Kulick, S. Yedlapalli, L. Battistella, C. J. Hajiran, and L. J. Sooter, "In vitro selection of a single-stranded DNA molecular recognition element specific for bromacil," Journal of Nucleic Acids, vol. 2014, Article ID 102968, 8 pages, 2014.

[17] U. B. Gyllensten and H. A. Erlich, "Generation of singlestranded DNA by the polymerase chain reaction and its application to direct sequencing of the HLA-DQA locus," Proceedings of the National Academy of Sciences of the United States of America, vol. 85, no. 20, pp. 7652-7656, 1988.

[18] T. Hultman, S. Stahl, E. Hornes, and M. Uhlen, "Direct solid phase sequencing of genomic and plasmid DNA using magnetic beads as solid support," Nucleic Acids Research, vol. 17, no. 13, pp. 4937-4946, 1989.

[19] M. J. Kujau and S. Wolfl, "Efficient preparation of singlestranded DNA for in vitro selection," Molecular Biotechnology, vol. 7, no. 3, pp. 333-335, 1997.

[20] R. Y. Walder, J. R. Hayes, and J. A. Walder, "Use of PCR primers containing a $3^{\prime}$-terminal ribose residue to prevent cross-contamination of amplified sequences," Nucleic Acids Research, vol. 21, no. 18, pp. 4339-4343, 1993.

[21] S. D. Mendonsa and M. T. Bowser, "In vitro selection of high-affinity DNA ligands for human IgE using capillary electrophoresis," Analytical Chemistry, vol. 76, no. 18, pp. 5387-5392, 2004.

[22] M. Berezovski, A. Drabovich, S. M. Krylova et al., "Nonequilibrium capillary electrophoresis of equilibrium mixtures: a universal tool for development of aptamers," Journal of the American Chemical Society, vol. 127, no. 9, pp. 3165-3171, 2005.

[23] J.-W. Park, R. Tatavarty, D. W. Kim, H.-T. Jung, and M. B. $\mathrm{Gu}$, "Immobilization-free screening of aptamers assisted by graphene oxide," Chemical Communications, vol. 48, no. 15, pp. 2071-2073, 2012.

[24] J.-W. Park, S. Jin Lee, E.-J. Choi, J. Kim, J.-Y. Song, and M. Bock $\mathrm{Gu}$, "An ultra-sensitive detection of a whole virus using dual aptamers developed by immobilization-free screening," Biosensors and Bioelectronics, vol. 51, pp. 324-329, 2014.
[25] V. Nguyen, Y. S. Kwon, J. H. Kim, and M. B. Gu, "Multiple GOSELEX for efficient screening of flexible aptamers," Chemical Communications, vol. 50, no. 72, p. 10513, 2014.

[26] R. Nutiu and Y. Li, "In vitro selection of structure-switching signaling aptamers," Angewandte Chemie International Edition, vol. 44, no. 7, pp. 1061-1065, 2005.

[27] J. He, Y. Liu, M. Fan, and X. Liu, "Isolation and identification of the DNA aptamer target to acetamiprid," Journal of Agricultural and Food Chemistry, vol. 59, no. 5, pp. 1582-1586, 2011.

[28] L. Wang, X. Liu, Q. Zhang et al., "Selection of DNA aptamers that bind to four organophosphorus pesticides," Biotechnology Letters, vol. 34, no. 5, pp. 869-874, 2012.

[29] R. Stoltenburg, C. Reinemann, and B. Strehlitz, "FluMagSELEX as an advantageous method for DNA aptamer selection," Analytical and Bioanalytical Chemistry, vol. 383, no. 1, pp. 83-91, 2005.

[30] J. B.-H. Tok and N. O. Fischer, "Single microbead SELEX for efficient ssDNA aptamer generation against botulinum neurotoxin," Chemical Communications, no. 16, pp. 1883-1885, 2008.

[31] L. H. Lauridsen, H. A. Shamaileh, S. L. Edwards, E. Taran, and R. N. Veedu, "Rapid one-step selection method for generating nucleic acid aptamers: development of a DNA Aptamer against alpha-bungarotoxin," PLoS ONE, vol. 7, no. 7, Article ID e41702, 2012.

[32] J. Qian, X. Lou, Y. Zhang, Y. Xiao, and H. T. Soh, "Generation of highly specific aptamers via micromagnetic selection," Analytical Chemistry, vol. 81, no. 13, pp. 5490-5495, 2009.

[33] X. Lou, J. Qian, Y. Xiao et al., "Micromagnetic selection of aptamers in microfluidic channels," Proceedings of the National Academy of Sciences of the United States of America, vol. 106, no. 9, pp. 2989-2994, 2009.

[34] H.-C. Lai, C.-H. Wang, T.-M. Liou, and G.-B. Lee, "Influenza A virus-specific aptamers screened by using an integrated microfluidic system," Lab on a Chip, vol. 14, no. 12, pp. 20022013, 2014.

[35] L. Cerchia, F. Ducongé, C. Pestourie et al., "Neutralizing aptamers from whole-cell SELEX inhibit the RET receptor tyrosine kinase," PLoS Biology, vol. 3, no. 4, article e123, 2005.

[36] D. A. Daniels, H. Chen, B. J. Hicke, K. M. Swiderek, and L. Gold, "A tenascin-C aptamer identified by tumor cell SELEX: systematic evolution of ligands by exponential enrichment," Proceedings of the National Academy of Sciences of the United States of America, vol. 100, no. 26, pp. 15416-15421, 2003.

[37] D. Shangguan, Y. Li, Z. Tang et al., "Aptamers evolved from live cells as effective molecular probes for cancer study," Proceedings of the National Academy of Sciences of the United States of America, vol. 103, no. 32, pp. 11838-11843, 2006.

[38] Z. Tang, D. Shangguan, K. Wang et al., "Selection of aptamers for molecular recognition and characterization of cancer cells," Analytical Chemistry, vol. 79, no. 13, pp. 4900-4907, 2007.

[39] J. Castro-Rosas, J. F. Cerna-Cortés, E. Méndez-Reyes, D. LopezHernandez, C. A. Gómez-Aldapa, and T. Estrada-Garcia, "Presence of faecal coliforms, Escherichia coli and diarrheagenic E. coli pathotypes in ready-to-eat salads, from an area where crops are irrigated with untreated sewage water," International Journal of Food Microbiology, vol. 156, no. 2, pp. 176-180, 2012.

[40] Z. Peng, M. Ling, Y. Ning, and L. Deng, "Rapid fluorescent detection of Escherichia coli K88 based on DNA aptamer library as direct and specific reporter combined with immunomagnetic separation," Journal of Fluorescence, vol. 24, no. 4, pp. 1159-1168, 2014. 
[41] H. Li, X. Ding, Z. Peng et al., "Aptamer selection for the detection of escherichia coli k88," Canadian Journal of Microbiology, vol. 57, no. 6, pp. 453-459, 2011.

[42] Y. S. Kim, M. Y. Song, J. Jurng, and B. C. Kim, "Isolation and characterization of DNA aptamers against Escherichia coli using a bacterial cell-systematic evolution of ligands by exponential enrichment approach," Analytical Biochemistry, vol. 436, no. 1, pp. 22-28, 2013.

[43] N. Savory, J. Nzakizwanayo, K. Abe et al., "Selection of DNA aptamers against uropathogenic Escherichia coli NSM59 by quantitative PCR controlled Cell-SELEX," Journal of Microbiological Methods, vol. 104, pp. 94-100, 2014.

[44] J. G. Bruno, M. P. Carrillo, T. Phillips, and C. J. Andrews, "A novel screening method for competitive FRET-aptamers applied to E. coli assay development," Journal of Fluorescence, vol. 20, no. 6, pp. 1211-1223, 2010.

[45] J. G. Bruno, M. P. Carrillo, and T. Phillips, "In Vitro antibacterial effects of antilipopolysaccharide DNA aptamer-Clqrs complexes," Folia Microbiologica, vol. 53, no. 4, pp. 295-302, 2008.

[46] H. P. Dwivedi, R. D. Smiley, and L.-A. Jaykus, "Selection of DNA aptamers for capture and detection of Salmonella Typhimurium using a whole-cell SELEX approach in conjunction with cell sorting," Applied Microbiology and Biotechnology, vol. 97, no. 8, pp. 3677-3686, 2013.

[47] N. Duan, S. Wu, X. Chen et al., "Selection and characterization of aptamers against salmonella typhimurium using wholebacterium systemic evolution of Ligands by exponential enrichment (SELEX)," Journal of Agricultural and Food Chemistry, vol. 61, no. 13, pp. 3229-3234, 2013.

[48] J. Moon, G. Kim, S. Lee, and S. Park, "Identification of Salmonella typhimurium-specific DNA aptamers developed using whole-cell SELEX and FACS analysis," Journal of Microbiological Methods, vol. 95, no. 2, pp. 162-166, 2013.

[49] R. Joshi, H. Janagama, H. P. Dwivedi et al., "Selection, characterization, and application of DNA aptamers for the capture and detection of Salmonella enterica serovars," Molecular and Cellular Probes, vol. 23, no. 1, pp. 20-28, 2009.

[50] O. S. Kolovskaya, A. G. Savitskaya, T. N. Zamay et al., "Development of bacteriostatic DNA aptamers for salmonella," Journal of Medicinal Chemistry, vol. 56, no. 4, pp. 1564-1572, 2013.

[51] H. Park, I. A. Baig, S. Lee, J. Moon, and M. Yoon, "Development of ssDNA aptamers for the sensitive detection of Salmonella typhimurium and Salmonella enteritidis," Applied Biochemistry and Biotechnology, vol. 174, no. 2, pp. 793-802, 2014.

[52] M. Yang, Z. Peng, Y. Ning, Y. Chen, Q. Zhou, and L. Deng, "Highly specific and cost-efficient detection of Salmonella paratyphi A combining aptamers with single-walled carbon nanotubes," Sensors, vol. 13, no. 5, pp. 6865-6881, 2013.

[53] G. Liu, X. Yu, F. Xue et al., "Screening and preliminary application of a DNA aptamer for rapid detection of Salmonella O8," Microchimica Acta, vol. 178, no. 1-2, pp. 237-244, 2012.

[54] S. R. Rippey, "Infectious diseases associated with molluscan shellfish consumption," Clinical Microbiology Reviews, vol. 7, no. 4, pp. 419-425, 1994.

[55] N. Duan, S. Wu, X. Chen, Y. Huang, and Z. Wang, "Selection and identification of a DNA aptamer targeted to Vibrio parahemolyticus," Journal of Agricultural and Food Chemistry, vol. 60, no. 16, pp. 4034-4038, 2012.

[56] X. Tang, J. Zheng, Q. Yan, Z. Li, and Y. Li, "Selection of aptamers against inactive Vibrio alginolyticus and application in a qualitative detection assay," Biotechnology Letters, vol. 35, no. 6, pp. 909-914, 2013.
[57] S. H. Suh, H. P. Dwivedi, S. J. Choi, and L. Jaykus, "Selection and characterization of DNA aptamers specific for Listeria species," Analytical Biochemistry, vol. 459, pp. 39-45, 2014.

[58] S. H. Suh and L.-A. Jaykus, "Nucleic acid aptamers for capture and detection of Listeria spp," Journal of Biotechnology, vol. 167, no. 4, pp. 454-461, 2013.

[59] N. Duan, X. Ding, L. He, S. Wu, Y. Wei, and Z. Wang, "Selection, identification and application of a DNA aptamer against Listeria monocytogenes," Food Control, vol. 33, no. 1, pp. 239-243, 2013.

[60] G.-Q. Liu, Y.-Q. Lian, C. Gao et al., "In vitro selection of DNA aptamers and fluorescence-based recognition for rapid detection Listeria monocytogenes," Journal of Integrative Agriculture, vol. 13, no. 5, pp. 1121-1129, 2014.

[61] H. Bierne, C. Sabet, N. Personnic, and P. Cossart, "Internalins: a complex family of leucine-rich repeat-containing proteins in Listeria monocytogenes," Microbes and Infection, vol. 9, no. 10, pp. 1156-1166, 2007.

[62] S. H. Ohk, O. K. Koo, T. Sen, C. M. Yamamoto, and A. K. Bhunia, "Antibody-aptamer functionalized fibre-optic biosensor for specific detection of Listeria monocytogenes from food," Journal of Applied Microbiology, vol. 109, no. 3, pp. 808-817, 2010.

[63] K. L. Kotloff, J. P. Winickoff, B. Ivanoff et al., "Global burden of Shigella infections: implications for vaccine development and implementation of control strategies," Bulletin of the World Health Organization, vol. 77, no. 8, pp. 651-666, 1999.

[64] N. Duan, X. Ding, S. Wu et al., "In vitro selection of a DNA aptamer targeted against Shigella dysenteriae," Journal of Microbiological Methods, vol. 94, no. 3, pp. 170-174, 2013.

[65] C. R. Friedman, R. M. Hoekstra, M. Samuel et al., "Risk factors for sporadic Campylobacter infection in the United States: a case-control study in FoodNet sites," Clinical Infectious Diseases, vol. 38, no. 3, pp. S285-S296, 2004.

[66] J. G. Bruno, T. Phillips, M. P. Carrillo, and R. Crowell, "Plastic-adherent DNA aptamer-magnetic bead and quantum dot sandwich assay for Campylobacter detection," Journal of Fluorescence, vol. 19, no. 3, pp. 427-435, 2009.

[67] D. N. Stratis-Cullum, S. McMasters, and P. M. Pellegrino, "Evaluation of relative aptamer binding to Campylobacter jejuni bacteria using affinity probe capillary electrophoresis," Analytical Letters, vol. 42, no. 15, pp. 2389-2402, 2009.

[68] H. P. Dwivedi, R. D. Smiley, and L.-A. Jaykus, "Selection and characterization of DNA aptamers with binding selectivity to Campylobacter jejuni using whole-cell SELEX," Applied Microbiology and Biotechnology, vol. 87, no. 6, pp. 2323-2334, 2010.

[69] N. Savory, D. Lednor, K. Tsukakoshi et al., "In silico maturation of binding-specificity of DNA aptamers against Proteus mirabilis," Biotechnology and Bioengineering, vol. 110, no. 10, pp. 2573-2580, 2013.

[70] N. Savory, Y. Takahashi, K. Tsukakoshi et al., "Simultaneous improvement of specificity and affinity of aptamers against Streptococcus mutans by in silico maturation for biosensor development," Biotechnology and Bioengineering, vol. 111, no. 3, pp. 454-461, 2014.

[71] A. C. Steer, T. Lamagni, N. Curtis, and J. R. Carapetis, "Invasive group a streptococcal disease: epidemiology, pathogenesis and management," Drugs, vol. 72, no. 9, pp. 1213-1227, 2012.

[72] C. L. A. Hamula, X. C. Le, and X.-F. Li, "DNA aptamers binding to multiple prevalent M-types of streptococcus pyogenes," Analytical Chemistry, vol. 83, no. 10, pp. 3640-3647, 2011.

[73] F. D. Lowy, "Staphylococcus aureus infections," The New England Journal of Medicine, vol. 339, no. 8, pp. 520-532, 1998. 
[74] X. Cao, S. Li, L. Chen et al., "Combining use of a panel of ssDNA aptamers in the detection of Staphylococcus aureus," Nucleic Acids Research, vol. 37, no. 14, pp. 4621-4628, 2009.

[75] Y.-C. Chang, C.-Y. Yang, R.-L. Sun, Y.-F. Cheng, W.-C. Kao, and P.-C. Yang, "Rapid single cell detection of Staphylococcus aureus by aptamer-conjugated gold nanoparticles," Scientific Reports, vol. 3, article 1863, 2013.

[76] A. E. Ballok and G. A. O’Toole, "Pouring salt on a wound: pseudomonas aeruginosa virulence factors alter $\mathrm{Na}+$ and $\mathrm{Cl}$ flux in the lung," Journal of Bacteriology, vol. 195, no. 18, pp. 4013-4019, 2013.

[77] M. I. Gómez and A. Prince, "Opportunistic infections in lung disease: pseudomonas infections in cystic fibrosis," Current Opinion in Pharmacology, vol. 7, no. 3, pp. 244-251, 2007.

[78] K.-Y. Wang, Y.-L. Zeng, X.-Y. Yang, W.-B. Li, and X.-P. Lan, "Utility of aptamer-fluorescence in situ hybridization for rapid detection of Pseudomonas aeruginosa," European Journal of Clinical Microbiology and Infectious Diseases, vol. 30, no. 2, pp. 273-278, 2011.

[79] D. Maher, M. Uplekar, L. Blanc, and M. Raviglione, "Treatment of tuberculosis," The British Medical Journal, vol. 327, no. 7419, pp. 822-823, 2003.

[80] F. Chen, J. Zhou, F. Luo, A. B. Mohammed, and X.-L. Zhang, "Aptamer from whole-bacterium SELEX as new therapeutic reagent against virulent Mycobacterium tuberculosis," Biochemical and Biophysical Research Communications, vol. 357, no. 3, pp. 743-748, 2007.

[81] J. A. Jernigan, D. S. Stephens, D. A. Ashford et al., "Bioterrorismrelated inhalational anthrax: the first 10 cases reported in the United States," Emerging Infectious Diseases, vol. 7, no. 6, pp. 933-944, 2001.

[82] J. G. Bruno and J. L. Kiel, "In vitro selection of DNA aptamers to anthrax spores with electrochemiluminescence detection," Biosensors and Bioelectronics, vol. 14, no. 5, pp. 457-464, 1999.

[83] M. Ikanovic, W. E. Rudzinski, J. G. Bruno et al., "Fluorescence assay based on aptamer-quantum dot binding to bacillus thuringiensis spores," Journal of Fluorescence, vol. 17, no. 2, pp. 193-199, 2007.

[84] J. G. Bruno and M. P. Carrillo, "Development of aptamer beacons for rapid presumptive detection of Bacillus spores," Journal of Fluorescence, vol. 22, no. 3, pp. 915-924, 2012.

[85] A. Tärnvik, "Nature of protective immunity to Francisella tularensis," Reviews of Infectious Diseases, vol. 11, no. 3, pp. 440451, 1989.

[86] J. Vivekananda and J. L. Kiel, "Anti-Francisella tularensis DNA aptamers detect tularemia antigen from different subspecies by Aptamer-Linked Immobilized Sorbent Assay," Laboratory Investigation, vol. 86, no. 6, pp. 610-618, 2006.

[87] A. Typas, M. Banzhaf, C. A. Gross, and W. Vollmer, "From the regulation of peptidoglycan synthesis to bacterial growth and morphology," Nature Reviews Microbiology, vol. 10, no. 2, pp. 123-136, 2012.

[88] I. M. Ferreira, C. M. de Souza Lacerda, L. S. de Faria, C. R. Corrêa, and A. S. de Andrade, "Selection of peptidoglycanspecific aptamers for bacterial cells identification," Applied Biochemistry and Biotechnology, vol. 174, no. 7, pp. 2548-2556, 2014.

[89] A. Preston, R. E. Mandrell, B. W. Gibson, and M. A. Apicella, "The lipooligosaccharides of pathogenic gram-negative bacteria," Critical Reviews in Microbiology, vol. 22, no. 3, pp. 139-180, 1996.
[90] R. J. Ulevitch and P. S. Tobias, "Receptor-dependent mechanisms of cell stimulation by bacterial endotoxin," Annual Review of Immunology, vol. 13, pp. 437-457, 1995.

[91] S.-E. Kim, W. Su, M. Cho, Y. Lee, and W.-S. Choe, "Harnessing aptamers for electrochemical detection of endotoxin," Analytical Biochemistry, vol. 424, no. 1, pp. 12-20, 2012.

[92] H. L. Koo, N. Ajami, R. L. Atmar, and H. L. DuPont, "Noroviruses: the leading cause of gastroenteritis worldwide," Discovery Medicine, vol. 10, no. 50, pp. 61-70, 2010.

[93] A. Giamberardino, M. Labib, E. M. Hassan et al., "Ultrasensitive norovirus detection using DNA aptasensor technology," PLoS ONE, vol. 8, no. 11, Article ID e79087, 2013.

[94] B. I. Escudero-Abarca, S. H. Suh, M. D. Moore, H. P. Dwivedi, L. Jaykus, and R. C. Willson, "Selection, characterization and application of nucleic acid aptamers for the capture and detection of human norovirus strains," PLoS ONE, vol. 9, no. 9, Article ID e106805, 2014.

[95] R. Beier, C. Pahlke, P. Quenzel et al., "Selection of a DNA aptamer against norovirus capsid protein VP1," FEMS Microbiology Letters, vol. 351, no. 2, pp. 162-169, 2014.

[96] R. Eccles, "Understanding the symptoms of the common cold and influenza," Lancet Infectious Diseases, vol. 5, no. 11, pp. 718$725,2005$.

[97] R. Wang, J. Zhao, T. Jiang et al., "Selection and characterization of DNA aptamers for use in detection of avian influenza virus H5N1," Journal of Virological Methods, vol. 189, no. 2, pp. 362369,2013

[98] I. Shiratori, J. Akitomi, D. A. Boltz, K. Horii, M. Furuichi, and I. Waga, "Selection of DNA aptamers that bind to influenza A viruses with high affinity and broad subtype specificity," Biochemical and Biophysical Research Communications, vol. 443, no. 1, pp. 37-41, 2014.

[99] Q. He, Q. Du, S. Lau et al., "Characterization of monoclonal antibody against SARS coronavirus nucleocapsid antigen and development of an antigen capture ELISA," Journal of Virological Methods, vol. 127, no. 1, pp. 46-53, 2005.

[100] F. Chen, Y. Hu, D. Li, H. Chen, and X.-L. Zhang, "CS-SELEX generates high-affinity ssDNA aptamers as molecular probes for hepatitis C virus envelope glycoprotein E2," PLoS ONE, vol. 4, no. 12, Article ID e8142, 2009.

[101] I. A. Rodenhuis-Zybert, J. Wilschut, and J. M. Smit, "Dengue virus life cycle: viral and host factors modulating infectivity," Cellular and Molecular Life Sciences, vol. 67, no. 16, pp. 27732786, 2010.

[102] S. H. Gandham, D. E. Volk, G. L. Lokesh, M. Neerathilingam, and D. G. Gorenstein, "Thioaptamers targeting dengue virus type-2 envelope protein domain III," Biochemical and Biophysical Research Communications, vol. 453, no. 3, pp. 309-315, 2014.

[103] R. K. Mosing, S. D. Mendonsa, and M. T. Bowser, "Capillary electrophoresis-SELEX selection of aptamers with affinity for HIV-1 reverse transcriptase," Analytical Chemistry, vol. 77, no. 19, pp. 6107-6112, 2005.

[104] E. Scallan, R. M. Hoekstra, F. J. Angulo et al., "Foodborne illness acquired in the United States-major pathogens," Emerging Infectious Diseases, vol. 17, no. 1, pp. 7-15, 2011.

[105] J. G. Bruno and J. L. Kiel, "Use of magnetic beads in selection and detection of biotoxin aptamers by electrochemiluminescence and enzymatic methods," BioTechniques, vol. 32, no. 1, pp. 178-183, 2002.

[106] Y. Huang, X. Chen, N. Duan et al., "Selection and characterization of DNA aptamers against Staphylococcus aureus enterotoxin C1," Food Chemistry, vol. 166, pp. 623-629, 2015. 
[107] J. G. Bartlett and D. N. Gerding, "Clinical recognition and diagnosis of Clostridium difficile infection," Clinical Infectious Diseases, vol. 46, supplement 1, pp. S12-S18, 2008.

[108] S. Perelle, M. Gibert, P. Bourlioux, G. Corthier, and M. R. Popoff, "Production of a complete binary toxin (actin-specific ADP- ribosyltransferase) by Clostridium difficile CD196," Infection and Immunity, vol. 65, no. 4, pp. 1402-1407, 1997.

[109] U. A. Ochsner, E. Katilius, and N. Janjic, "Detection of Clostridium difficile toxins $\mathrm{A}, \mathrm{B}$ and binary toxin with slow off-rate modified aptamers," Diagnostic Microbiology and Infectious Disease, vol. 76, no. 3, pp. 278-285, 2013.

[110] U. A. Ochsner, L. S. Green, L. Gold, and N. Janjic, "Systematic selection of modified aptamer pairs for diagnostic sandwich assays," BioTechniques, vol. 56, no. 3, pp. 125-133, 2014.

[111] K. L. Hong, E. Maher, R. M. Williams, and L. J. Sooter, "In vitro selection of single-stranded DNA molecular recognition elements against Clostridium difficile toxin B and sensitive detection in human fecal matter," Journal of Nucleic Acids, vol. 2015, Article ID 808495, 12 pages, 2015.

[112] N. R. Gandhi, P. Nunn, K. Dheda et al., "Multidrug-resistant and extensively drug-resistant tuberculosis: a threat to global control of tuberculosis," The Lancet, vol. 375, no. 9728, pp. 18301843, 2010.

[113] K. R. Steingart, M. Henry, V. Ng et al., "Fluorescence versus conventional sputum smear microscopy for tuberculosis: a systematic review," The Lancet Infectious Diseases, vol. 6, no. 9, pp. 570-581, 2006.

[114] K. R. Steingart, V. Ng, M. Henry et al., "Sputum processing methods to improve the sensitivity of smear microscopy for tuberculosis: a systematic review," The Lancet Infectious Diseases, vol. 6, no. 10, pp. 664-674, 2006.

[115] X. Tang, Y. Zhou, S. Wu, Q. Pan, B. Xia, and X. Zhang, "CFP10 and ESAT6 aptamers as effective Mycobacterial antigen diagnostic reagents," Journal of Infection, vol. 69, no. 6, pp. 569580, 2014.

[116] J. T. R. Wilcke, B. N. Jensen, P. Ravn, Å. B. Andersen, and K. Hasløv, "Clinical evaluation of MPT-64 and MPT-59, two proteins secreted from Mycobacterium tuberculosis, for skin test reagents," Tubercle and Lung Disease, vol. 77, no. 3, pp. 250-256, 1996.

[117] L. Qin, R. Zheng, Z. Ma et al., "The selection and application of ssDNA aptamers against MPT64 protein in Mycobacterium tuberculosis," Clinical Chemistry and Laboratory Medicine, vol. 47, no. 4, pp. 405-411, 2009.

[118] R. J. Collier and J. A. T. Young, "Anthrax toxin," Annual Review of Cell and Developmental Biology, vol. 19, pp. 45-70, 2003.

[119] L. N. Cella, P. Sanchez, W. Zhong, N. V. Myung, W. Chen, and A. Mulchandani, "Nano aptasensor for protective antigen toxin of anthrax," Analytical Chemistry, vol. 82, no. 5, pp. 2042-2047, 2010.

[120] J. S. Choi, S. G. Kim, M. Lahousse et al., "Screening and characterization of high-affinity ssDNA aptamers against anthrax protective antigen," Journal of Biomolecular Screening, vol. 16, no. 2, pp. 266-271, 2011.

[121] R. K. Dhaked, M. K. Singh, P. Singh, and P. Gupta, "Botulinum toxin: bioweapon \& magic drug," Indian Journal of Medical Research, vol. 132, no. 11, pp. 489-503, 2010.

[122] J. G. Bruno, A. M. Richarte, M. P. Carrillo, and A. Edge, "An aptamer beacon responsive to botulinum toxins," Biosensors and Bioelectronics, vol. 31, no. 1, pp. 240-243, 2012.
[123] C. Nakamura, T. Kobayashi, M. Miyake, M. Shirai, and J. Miyake, "Usage of a DNA aptamer as a ligand targeting microcystin," Molecular Crystals and Liquid Crystals Science and Technology Section A, vol. 371, no. 1, pp. 369-374, 2001.

[124] A. T. C. Bourke and R. B. Hawes, "Freshwater cyanobacteria (blue-green algae) and human health," Medical Journal of Australia, vol. 1, no. 11, pp. 491-492, 1983.

[125] R. Elshafey, M. Siaj, and M. Zourob, "In vitro selection, characterization, and biosensing application of high-affinity cylindrospermopsin-targeting aptamers," Analytical Chemistry, vol. 86, no. 18, pp. 9196-9203, 2014.

[126] M.-L. Andreola, F. Pileur, C. Calmels et al., "DNA aptamers selected against the HIV-1 RNase $\mathrm{H}$ display in vitro antiviral activity," Biochemistry, vol. 40, no. 34, pp. 10087-10094, 2001.

[127] J. J. DeStefano and G. R. Nair, "Novel aptamer inhibitors of human immunodeficiency virus reverse transcriptase," Oligonucleotides, vol. 18, no. 2, pp. 133-144, 2008.

[128] D. J. Schneider, "High-affinity ssDNA inhibitors of the reverse transcriptase of type 1 human immunodeficiency virus," Biochemistry, vol. 34, no. 29, pp. 9599-9610, 1995.

[129] Y.-T. Lai and J. J. DeStefano, "DNA aptamers to human immunodeficiency virus reverse transcriptase selected by a primer-free SELEX method: characterization and comparison with other aptamers," Nucleic Acid Therapeutics, vol. 22, no. 3, pp. 162-176, 2012.

[130] V. R. De Soultrait, P.-Y. Lozach, R. Altmeyer, L. Tarrago-Litvak, S. Litvak, and M. L. Andréola, "DNA aptamers derived from HIV-1 RNase $\mathrm{H}$ inhibitors are strong anti-integrase agents," Journal of Molecular Biology, vol. 324, no. 2, pp. 195-203, 2002.

[131] N. Jing and M. E. Hogan, "Structure-activity of tetrad-forming oligonucleotides as a potent anti-HIV therapeutic drug," The Journal of Biological Chemistry, vol. 273, no. 52, pp. 3499234999, 1998.

[132] C. Boiziau, E. Dausse, L. Yurchenko, and J.-J. Toulmé, “DNA aptamers selected against the HIV-1 trans-activation-responsive RNA element form RNA-DNA kissing complexes," The Journal of Biological Chemistry, vol. 274, no. 18, pp. 12730-12737, 1999.

[133] D. Sekkai, E. Dausse, C. di Primo, F. Darfeuille, C. Boiziau, and J. J. Toulmé, "In vitro selection of DNA aptamers against the HIV-1 TAR RNA hairpin," Antisense and Nucleic Acid Drug Development, vol. 12, no. 4, pp. 265-274, 2002.

[134] P. Bellecave, C. Cazenave, J. Rumi et al., "Inhibition of hepatitis $\mathrm{C}$ virus (HCV) RNA polymerase by DNA aptamers: mechanism of inhibition of in vitro RNA synthesis and effect on HCVinfected cells," Antimicrobial Agents and Chemotherapy, vol. 52, no. 6, pp. 2097-2110, 2008.

[135] Z. Zhang, J. Zhang, X. Pei et al., "An aptamer targets HBV core protein and suppresses HBV replication in HepG2.2.15 cells," International Journal of Molecular Medicine, vol. 34, no. 5, pp. 1423-1429, 2014.

[136] K. T. Shum and J. A. Tanner, "Differential inhibitory activities and stabilisation of DNA aptamers against the SARS coronavirus helicase," Chembiochem, vol. 9, no. 18, pp. 3037-3045, 2008.

[137] S. H. Jeon, B. Kayhan, T. Ben-Yedidia, and R. Arnon, "A DNA aptamer prevents influenza infection by blocking the receptor binding region of the viral hemagglutinin," Journal of Biological Chemistry, vol. 279, no. 46, pp. 48410-48419, 2004.

[138] C. Cheng, J. Dong, L. Yao et al., "Potent inhibition of human influenza H5N1 virus by oligonucleotides derived by SELEX," Biochemical and Biophysical Research Communications, vol. 366, no. 3, pp. 670-674, 2008. 
[139] M. Wongphatcharachai, P. Wang, S. Enomoto et al., "Neutralizing DNA aptamers against swine influenza H3N2 viruses," Journal of Clinical Microbiology, vol. 51, no. 1, pp. 46-54, 2013.

[140] S. K. Choi, C. Lee, K. S. Lee et al., "DNA aptamers against the receptor binding region of hemagglutinin prevent avian influenza viral infection," Molecules and Cells, vol. 32, no. 6, pp. 527-533, 2011.

[141] H.-M. Woo, K.-S. Kim, J.-M. Lee et al., "Single-stranded DNA aptamer that specifically binds to the influenza virus NS1 protein suppresses interferon antagonism," Antiviral Research, vol. 100, no. 2, pp. 337-345, 2013.

[142] H. R. Liang, G. Q. Hu, T. Zhang et al., "Isolation of ssDNA aptamers that inhibit rabies virus," International Immunopharmacology, vol. 14, no. 3, pp. 341-347, 2012.

[143] J. C. Graham and H. Zarbl, "Use of cell-SELEX to generate DNA aptamers as molecular probes of HPV-associated cervical cancer cells," PLoS ONE, vol. 7, no. 4, Article ID e36103, 2012.

[144] A. Nitsche, A. Kurth, A. Dunkhorst et al., "One-step selection of Vaccinia virus-binding DNA aptamers by MonoLEX," $B M C$ Biotechnology, vol. 7, article 48, 2007.

[145] S. M. Handy, B. J. Yakes, J. A. DeGrasse et al., "First report of the use of a saxitoxin-protein conjugate to develop a DNA aptamer to a small molecule toxin," Toxicon, vol. 61, no. 1, pp. 30-37, 2013.

[146] J. A. Cruz-Aguado and G. Penner, "Determination of ochratoxin A with a DNA aptamer," Journal of Agricultural and Food Chemistry, vol. 56, no. 22, pp. 10456-10461, 2008.

[147] J. A. Cruz-Aguado and G. Penner, "Fluorescence polarization based displacement assay for the determination of small molecules with aptamers," Analytical Chemistry, vol. 80, no. 22, pp. 8853-8855, 2008.

[148] L. Barthelmebs, J. Jonca, A. Hayat, B. Prieto-Simon, and J.-L. Marty, "Enzyme-Linked Aptamer Assays (ELAAs), based on a competition format for a rapid and sensitive detection of Ochratoxin A in wine," Food Control, vol. 22, no. 5, pp. 737-743, 2011.

[149] M. McKeague, R. Velu, K. Hill, V. Bardóczy, T. Mészáros, and M. DeRosa, "Selection and characterization of a novel DNA aptamer for label-free fluorescence biosensing of ochratoxin A," Toxins, vol. 6, no. 8, pp. 2435-2452, 2014.

[150] X. Chen, Y. Huang, N. Duan et al., "Selection and identification of ssDNA aptamers recognizing zearalenone," Analytical and Bioanalytical Chemistry, vol. 405, no. 20, pp. 6573-6581, 2013.

[151] X. Chen, Y. Huang, N. Duan et al., "Screening and identification of DNA aptamers against T-2 Toxin assisted by graphene oxide," Journal of Agricultural and Food Chemistry, vol. 62, no. 42, pp. 10368-10374, 2014.

[152] X. Ma, W. Wang, X. Chen et al., "Selection, identification, and application of Aflatoxin B1 aptamer," European Food Research and Technology, vol. 238, no. 6, pp. 919-925, 2014.

[153] S. Malhotra, A. K. Pandey, Y. S. Rajput, and R. Sharma, "Selection of aptamers for aflatoxin M1 and their characterization," Journal of Molecular Recognition, vol. 27, no. 8, pp. 493-500, 2014.

[154] K. L. Hong, L. Battistella, A. D. Salva, R. M. Williams, and L. J. Sooter, "In vitro selection of single-stranded DNA molecular recognition elements against $S$. aureus alpha toxin and sensitive detection in human serum," International Journal of Molecular Sciences, vol. 16, no. 2, pp. 2794-2809, 2015.

[155] J. Vivekananda, C. Salgado, and N. J. Millenbaugh, "DNA aptamers as a novel approach to neutralize Staphylococcus aureus $\alpha$-toxin," Biochemical and Biophysical Research Communications, vol. 444, no. 3, pp. 433-438, 2014.
[156] Y. S. Kim, H. S. Jung, T. Matsuura, H. Y. Lee, T. Kawai, and M. B. Gu, "Electrochemical detection of 17beta-estradiol using DNA aptamer immobilized gold electrode chip," Biosensors and Bioelectronics, vol. 22, no. 11, pp. 2525-2531, 2007.

[157] O. A. Alsager, S. Kumar, G. R. Willmott, K. P. McNatty, and J. M. Hodgkiss, "Small molecule detection in solution via the size contraction response of aptamer functionalized nanoparticles," Biosensors and Bioelectronics, vol. 57, pp. 262-268, 2014.

[158] M. Jo, J.-Y. Ahn, J. Lee et al., "Development of single-stranded DNA aptamers for specific bisphenol a detection," Oligonucleotides, vol. 21, no. 2, pp. 85-91, 2011.

[159] S. Xu, H. Yuan, S. Chen, A. Xu, J. Wang, and L. Wu, "Selection of DNA aptamers against polychlorinated biphenyls as potential biorecognition elements for environmental analysis," Analytical Biochemistry, vol. 423, no. 2, pp. 195-201, 2012.

[160] J. Mehta, E. Rouah-Martin, B. van Dorst et al., "Selection and characterization of PCB-binding DNA aptamers," Analytical Chemistry, vol. 84, no. 3, pp. 1669-1676, 2012.

[161] P. E. Sanchez, DNA Aptamer Development for Detection of Atrazine and Protective Antigen Toxin Using Fluorescence Polarization, Microbiology, University of California, Riverside, Calif, USA, 2012.

[162] W. Wu, Z. Fang, S. Zhao et al., "A simple aptamer biosensor for Salmonellae enteritidis based on fluorescence-switch signaling graphene oxide," RSC Advances, vol. 4, no. 42, pp. 22009-22012, 2014.

[163] Z. Fang, W. Wu, X. Lu, and L. Zeng, "Lateral flow biosensor for DNA extraction-free detection of salmonella based on aptamer mediated strand displacement amplification," Biosensors and Bioelectronics, vol. 56, pp. 192-197, 2014.

[164] J. Yuan, Z. Tao, Y. Yu et al., "A visual detection method for Salmonella Typhimurium based on aptamer recognition and nanogold labeling," Food Control, vol. 37, no. 1, pp. 188-192, 2014.

[165] X. Ma, Y. Jiang, F. Jia, Y. Yu, J. Chen, and Z. Wang, “An aptamer-based electrochemical biosensor for the detection of Salmonella," Journal of Microbiological Methods, vol. 98, no. 1, pp. 94-98, 2014.

[166] M. Labib, A. S. Zamay, O. S. Kolovskaya et al., "Aptamer-based impedimetric sensor for bacterial typing," Analytical Chemistry, vol. 84, no. 19, pp. 8114-8117, 2012.

[167] W. Wu, J. Li, D. Pan et al., "Gold nanoparticle-based enzymelinked antibody-aptamer sandwich assay for detection of Salmonella typhimurium," ACS Applied Materials \& Interfaces, vol. 6, no. 19, pp. 16974-16981, 2014.

[168] N. Duan, S. Wu, Y. Yu et al., "A dual-color flow cytometry protocol for the simultaneous detection of Vibrio parahaemolyticus and Salmonella typhimurium using aptamer conjugated quantum dots as labels," Analytica Chimica Acta, vol. 804, pp. 151-158, 2013.

[169] N. Duan, S. Wu, C. Zhu et al., "Dual-color upconversion fluorescence and aptamer-functionalized magnetic nanoparticlesbased bioassay for the simultaneous detection of Salmonella Typhimurium and Staphylococcus aureus," Analytica Chimica Acta, vol. 723, pp. 1-6, 2012.

[170] G. A. Zelada-Guillén, J. L. Sebastián-Avila, P. Blondeau, J. Riu, and F. X. Rius, "Label-free detection of Staphylococcus aureus in skin using real-time potentiometric biosensors based on carbon nanotubes and aptamers," Biosensors and Bioelectronics, vol. 31, no. 1, pp. 226-232, 2012.

[171] R. Hernández, C. Vallés, A. M. Benito, W. K. Maser, F. Xavier Rius, and J. Riu, "Graphene-based potentiometric biosensor 
for the immediate detection of living bacteria," Biosensors and Bioelectronics, vol. 54, pp. 553-557, 2014.

[172] J. Yuan, S. Wu, N. Duan et al., "A sensitive gold nanoparticlebased colorimetric aptasensor for Staphylococcus aureus," Talanta, vol. 127, pp. 163-168, 2014.

[173] X. Shi, F. He, Y. Lian, D. Yan, and X. Zhang, "A new aptamer/SWNTs IDE-SPQC sensor for rapid and specific detection of Group A Streptococcus," Sensors and Actuators, B: Chemical, vol. 198, pp. 431-437, 2014.

[174] Y. S. Kim, J. Chung, M. Y. Song, J. Jurng, and B. C. Kim, "Aptamer cocktails: enhancement of sensing signals compared to single use of aptamers for detection of bacteria," Biosensors and Bioelectronics, vol. 54, pp. 195-198, 2014.

[175] W.-H. Wu, M. Li, Y. Wang et al., "Aptasensors for rapid detection of Escherichia coli O157: H7 and Salmonella typhimurium," Nanoscale Research Letters, vol. 7, no. 1, p. 658, 2012.

[176] C. Luo, Y. Lei, L. Yan et al., "A rapid and sensitive aptamer-based electrochemical biosensor for direct detection of Escherichia coli O111," Electroanalysis, vol. 24, no. 5, pp. 1186-1191, 2012.

[177] G. A. Zelada-Guillén, S. V. Bhosale, J. Riu, and F. X. Rius, "Realtime potentiometric detection of bacteria in complex samples," Analytical Chemistry, vol. 82, no. 22, pp. 9254-9260, 2010.

[178] L. H. Kim, H.-W. Yu, Y.-H. Kim, I. S. Kim, and A. Jang, "Potential of fluorophore labeled aptamers for Pseudomonas aeruginosa detection in drinking water," Journal of the Korean Society for Applied Biological Chemistry, vol. 56, no. 2, pp. 165171, 2013.

[179] S. Wu, N. Duan, Z. Shi, C. Fang, and Z. Wang, "Simultaneous aptasensor for multiplex pathogenic bacteria detection based on multicolor upconversion nanoparticles labels," Analytical Chemistry, vol. 86, no. 6, pp. 3100-3107, 2014.

[180] P. Zuo, X. Li, D. C. Dominguez, and B.-C. Ye, "A PDMS/paper/ glass hybrid microfluidic biochip integrated with aptamerfunctionalized graphene oxide nano-biosensors for one-step multiplexed pathogen detection," Lab on a Chip, vol. 13, no. 19, pp. 3921-3928, 2013.

[181] R. Wang and Y. Li, "Hydrogel based QCM aptasensor for detection of avian influenza virus," Biosensors and Bioelectronics, vol. 42, no. 1, pp. 148-155, 2013.

[182] M. Labib, A. S. Zamay, D. Muharemagic, A. V. Chechik, J. C. Bell, and M. V. Berezovski, "Aptamer-based viability impedimetric sensor for viruses," Analytical Chemistry, vol. 84, no. 4, pp. 1813-1816, 2012.

[183] H. Bai, R. Wang, B. Hargis, H. Lu, and Y. Li, "A SPR aptasensor for detection of avian influenza virus H5N1," Sensors, vol. 12, no. 9, pp. 12506-12518, 2012.

[184] H.-J. Zhang, Y.-H. Lu, Y.-J. Long et al., "An aptamerfunctionalized gold nanoparticle biosensor for the detection of prion protein," Analytical Methods, vol. 6, no. 9, pp. 2982-2987, 2014.

[185] P. Luo, Y. Liu, Y. Xia, H. Xu, and G. Xie, "Aptamer biosensor for sensitive detection of toxin A of Clostridium difficile using gold nanoparticles synthesized by Bacillus stearothermophilus," Biosensors and Bioelectronics, vol. 54, pp. 217-221, 2014.

[186] R. Deng, L. Wang, G. Yi, E. Hua, and G. Xie, "Target-induced aptamer release strategy based on electrochemical detection of staphylococcal enterotoxin B using GNPs-ZrO2-Chits film," Colloids and Surfaces B: Biointerfaces, vol. 120, pp. 1-7, 2014.

[187] E. Temur, A. Zengin, I. H. Boyacä, F. C. Dudak, H. Torul, and U. Tamer, "Attomole sensitivity of staphylococcal enterotoxin b detection using an aptamer-modified surface-enhanced Raman scattering probe," Analytical Chemistry, vol. 84, no. 24, pp. 10600-10606, 2012.

[188] R. Zhao, Y. Wen, J. Yang, J. Zhang, and X. Yu, "Aptasensor for Staphylococcus enterotoxin B detection using high SNR piezoresistive microcantilevers," Journal of Microelectromechanical Systems, vol. 23, no. 5, pp. 1054-1062, 2014.

[189] R. B. Queiros, C. Gouveia, J. R. Fernandes, and P. A. Jorge, "Evanescent wave DNA-aptamer biosensor based on long period gratings for the specific recognition of $E$. coli outer membrane proteins," Biosensors and Bioelectronics, vol. 62, pp. 227-233, 2014.

[190] R. B. Queirós, N. de-Los-Santos-Álvarez, J. P. Noronha, and M. G. F. Sales, "A label-free DNA aptamer-based impedance biosensor for the detection of E. coliouter membrane proteins," Sensors and Actuators B: Chemical, vol. 181, pp. 766-772, 2013.

[191] F. Wei and C.-M. Ho, "Aptamer-based electrochemical biosensor for Botulinum neurotoxin," Analytical and Bioanalytical Chemistry, vol. 393, no. 8, pp. 1943-1948, 2009.

[192] X. Guo, F. Wen, N. Zheng et al., "Development of an ultrasensitive aptasensor for the detection of aflatoxin B1," Biosensors and Bioelectronics, vol. 56, pp. 340-344, 2014.

[193] W. B. Shim, M. J. Kim, H. Mun, and M. G. Kim, "An aptamerbased dipstick assay for the rapid and simple detection of aflatoxin B1," Biosensors and Bioelectronics, vol. 62, pp. 288-294, 2014.

[194] B. H. Nguyen, L. D. Tran, Q. P. Do, H. L. Nguyen, N. H. Tran, and P. X. Nguyen, "Label-free detection of aflatoxin $\mathrm{M} 1$ with electrochemical $\mathrm{Fe}_{3} \mathrm{O}_{4}$ /polyaniline-based aptasensor," Materials Science and Engineering C: Materials for Biological Applications, vol. 33, no. 4, pp. 2229-2234, 2013.

[195] C. Yang, Y. Wang, J.-L. Marty, and X. Yang, "Aptamer-based colorimetric biosensing of Ochratoxin A using unmodified gold nanoparticles indicator," Biosensors and Bioelectronics, vol. 26, no. 5, pp. 2724-2727, 2011.

[196] L. Jiang, J. Qian, X. Yang, Y. Yan, Q. Liu, and K. Wang, "Amplified impedimetric aptasensor based on gold nanoparticles covalently bound graphene sheet for the picomolar detection of ochratoxin A," Analytica Chimica Acta, vol. 806, pp. 128-135, 2014.

[197] Z. Lv, A. Chen, J. Liu et al., "A simple and sensitive approach for ochratoxin A detection using a label-free fluorescent aptasensor," PLoS ONE, vol. 9, no. 1, Article ID e85968, 2014.

[198] X. Yang, J. Qian, L. Jiang, Y. Yan, K. Wang, and Q. Liu, "Ultrasensitive electrochemical aptasensor for ochratoxin A based on two-level cascaded signal amplification strategy," Bioelectrochemistry, vol. 96, pp. 7-13, 2014.

[199] Y. Yuan, S. Wei, G. Liu, S. Xie, Y. Chai, and R. Yuan, "Ultrasensitive electrochemiluminescent aptasensor for ochratoxin A detection with the loop-mediated isothermal amplification," Analytica Chimica Acta, vol. 811, pp. 70-75, 2014.

[200] J. Chen, X. Zhang, S. Cai et al., "A fluorescent aptasensor based on DNA-scaffolded silver-nanocluster for ochratoxin A detection," Biosensors and Bioelectronics, vol. 57, pp. 226-231, 2014.

[201] J.-H. Park, J.-Y. Byun, H. Mun et al., "A regeneratable, label-free, localized surface plasmon resonance (LSPR) aptasensor for the detection of ochratoxin A," Biosensors and Bioelectronics, vol. 59, pp. 321-327, 2014.

[202] W. Ma, H. Yin, L. Xu et al., "Femtogram ultrasensitive aptasensor for the detection of Ochratoxin A," Biosensors and Bioelectronics, vol. 42, no. 1, pp. 545-549, 2013. 
[203] Q. Zhao, X. Geng, and H. Wang, "Fluorescent sensing ochratoxin A with single fluorophore-labeled aptamer," Analytical and Bioanalytical Chemistry, vol. 405, no. 19, pp. 6281-6286, 2013.

[204] X. Hun, F. Liu, Z. Mei, L. Ma, Z. Wang, and X. Luo, "Signal amplified strategy based on target-induced strand release coupling cleavage of nicking endonuclease for the ultrasensitive detection of ochratoxin A," Biosensors and Bioelectronics, vol. 39, no. 1, pp. 145-151, 2013.

[205] A. Hayat, A. Sassolas, J.-L. Marty, and A.-E. Radi, "Highly sensitive ochratoxin A impedimetric aptasensor based on the immobilization of azido-aptamer onto electrografted binary film via click chemistry," Talanta, vol. 103, pp. 14-19, 2013.

[206] A. Hayat, W. Haider, M. Rolland, and J.-L. Marty, "Electrochemical grafting of long spacer arms of hexamethyldiamine on a screen printed carbon electrode surface: application in target induced ochratoxin A electrochemical aptasensor," Analyst, vol. 138, no. 10, pp. 2951-2957, 2013.

[207] A. Hayat, S. Andreescu, and J.-L. Marty, "Design of PEGaptamer two piece macromolecules as convenient and integrated sensing platform: application to the label free detection of small size molecules," Biosensors and Bioelectronics, vol. 45, no. 1, pp. 168-173, 2013.

[208] L. Barthelmebs, A. Hayat, A. W. Limiadi, J.-L. Marty, and T. Noguer, "Electrochemical DNA aptamer-based biosensor for OTA detection, using superparamagnetic nanoparticles," Sensors and Actuators, B: Chemical, vol. 156, no. 2, pp. 932-937, 2011.

[209] A. Rhouati, A. Hayat, D. B. Hernandez, Z. Meraihi, R. Munoz, and J.-L. Marty, "Development of an automated flow-based electrochemical aptasensor for on-line detection of Ochratoxin A," Sensors and Actuators B: Chemical, vol. 176, pp. 1160-1166, 2013.

[210] L. Wang, W. Ma, W. Chen et al., "An aptamer-based chromatographic strip assay for sensitive toxin semi-quantitative detection," Biosensors and Bioelectronics, vol. 26, no. 6, pp. 30593062, 2011.

[211] L. Wang, W. Chen, W. Ma et al., "Fluorescent strip sensor for rapid determination of toxins," Chemical Communications, vol. 47, no. 5, pp. 1574-1576, 2011.

[212] L. Bonel, J. C. Vidal, P. Duato, and J. R. Castillo, "An electrochemical competitive biosensor for ochratoxin A based on a DNA biotinylated aptamer," Biosensors and Bioelectronics, vol. 26, no. 7, pp. 3254-3259, 2011.

[213] H. Kuang, W. Chen, D. Xu et al., "Fabricated aptamer-based electrochemical 'signal-off' sensor of ochratoxin A," Biosensors and Bioelectronics, vol. 26, no. 2, pp. 710-716, 2010.

[214] J. Zhang, J. Chen, X. Zhang, Z. Zeng, M. Chen, and S. Wang, "An electrochemical biosensor based on hairpin-DNA aptamer probe and restriction endonuclease for ochratoxin A detection," Electrochemistry Communications, vol. 25, pp. 5-7, 2012.

[215] J. Wu, H. Chu, Z. Mei et al., "Ultrasensitive one-step rapid detection of ochratoxin A by the folding-based electrochemical aptasensor," Analytica Chimica Acta, vol. 753, pp. 27-31, 2012.

[216] S. Wu, N. Duan, Z. Wang, and H. Wang, "Aptamerfunctionalized magnetic nanoparticle-based bioassay for the detection of ochratoxin A using upconversion nanoparticles as labels," Analyst, vol. 136, no. 11, pp. 2306-2314, 2011.

[217] G. Evtugyn, A. Porfireva, R. Sitdikov et al., "Electrochemical aptasensor for the determination of ochratoxin $\mathrm{A}$ at the $\mathrm{Au}$ electrode modified with Ag nanoparticles decorated with macrocyclic ligand," Electroanalysis, vol. 25, no. 8, pp. 18471854, 2013.

[218] S. Xie, Y. Chai, Y. Yuan, L. Bai, and R. Yuan, "Development of an electrochemical method for Ochratoxin A detection based on aptamer and loop-mediated isothermal amplification," Biosensors and Bioelectronics, vol. 55, pp. 324-329, 2014.

[219] J. Chen, Z. Fang, J. Liu, and L. Zeng, "A simple and rapid biosensor for ochratoxin A based on a structure-switching signaling aptamer," Food Control, vol. 25, no. 2, pp. 555-560, 2012.

[220] J. Zhang, X. Zhang, G. Yang, J. Chen, and S. Wang, "A signal-on fluorescent aptasensor based on $\mathrm{Tb} 3+$ and structure-switching aptamer for label-free detection of Ochratoxin A in wheat," Biosensors and Bioelectronics, vol. 41, no. 1, pp. 704-709, 2013.

[221] A. de Girolamo, L. Le, G. Penner, R. Schena, and A. Visconti, "Analytical performances of a DNA-ligand system using timeresolved fluorescence for the determination of ochratoxin A in wheat," Analytical and Bioanalytical Chemistry, vol. 403, no. 9, pp. 2627-2634, 2012.

[222] G. Castillo, I. Lamberti, L. Mosiello, and T. Hianik, "Impedimetric DNA aptasensor for sensitive detection of ochratoxin A in food," Electroanalysis, vol. 24, no. 3, pp. 512-520, 2012.

[223] N. Duan, S. Wu, X. Ma, X. Chen, Y. Huang, and Z. Wang, "Gold nanoparticle-based fluorescence resonance energy transfer aptasensor for ochratoxin A detection," Analytical Letters, vol. 45, no. 7, pp. 714-723, 2012.

[224] P. Tong, L. Zhang, J.-J. Xu, and H.-Y. Chen, "Simply amplified electrochemical aptasensor of Ochratoxin A based on exonuclease-catalyzed target recycling," Biosensors and Bioelectronics, vol. 29, no. 1, pp. 97-101, 2011.

[225] P. Tong, W.-W. Zhao, L. Zhang, J.-J. Xu, and H.-Y. Chen, "Double-probe signal enhancing strategy for toxin aptasensing based on rolling circle amplification," Biosensors and Bioelectronics, vol. 33, no. 1, pp. 146-151, 2012.

[226] L. Sheng, J. Ren, Y. Miao, J. Wang, and E. Wang, "PVP-coated graphene oxide for selective determination of ochratoxin A via quenching fluorescence of free aptamer," Biosensors and Bioelectronics, vol. 26, no. 8, pp. 3494-3499, 2011.

[227] Z. Wang, N. Duan, X. Hun, and S. Wu, "Electrochemiluminescent aptamer biosensor for the determination of ochratoxin $\mathrm{A}$ at a gold-nanoparticles-modified gold electrode using $\mathrm{N}$ (aminobutyl)-N-ethylisoluminol as a luminescent label," Analytical and Bioanalytical Chemistry, vol. 398, no. 5, pp. 21252132, 2010.

[228] C. Yang, V. Lates, B. Prieto-Simón, J.-L. Marty, and X. Yang, "Aptamer-DNAzyme hairpins for biosensing of Ochratoxin A," Biosensors and Bioelectronics, vol. 32, no. 1, pp. 208-212, 2012.

[229] C. Yang, V. Lates, B. Prieto-Simón, J.-L. Marty, and X. Yang, "Rapid high-throughput analysis of ochratoxin A by the selfassembly of DNAzyme-aptamer conjugates in wine," Talanta, vol. 116, pp. 520-526, 2013.

[230] Z. Guo, J. Ren, J. Wang, and E. Wang, "Single-walled carbon nanotubes based quenching of free FAM-aptamer for selective determination of ochratoxin A," Talanta, vol. 85, no. 5, pp. 25172521, 2011.

[231] N. Prabhakar, Z. Matharu, and B. D. Malhotra, "Polyaniline Langmuir-Blodgett film based aptasensor for ochratoxin A detection," Biosensors and Bioelectronics, vol. 26, no. 10, pp. 4006-4011, 2011.

[232] N. Duan, S.-J. Wu, and Z.-P. Wang, "An aptamer-based fluorescence assay for ochratoxin A," Chinese Journal of Analytical Chemistry, vol. 39, no. 3, pp. 300-304, 2011. 
[233] N. Yildirim, F. Long, M. He, H.-C. Shi, and A. Z. Gu, "A portable optic fiber aptasensor for sensitive, specific and rapid detection of bisphenol-A in water samples," Environmental Sciences: Processes and Impacts, vol. 16, no. 6, pp. 1379-1386, 2014.

[234] D. Yao, A. Liang, W. Yin, and Z. Jiang, "Resonance light scattering determination of trace bisphenol A with signal amplification by aptamer-nanogold catalysis," Luminescence, vol. 29, no. 5, pp. 516-521, 2014.

[235] L. Zhou, J. Wang, D. Li, and Y. Li, "An electrochemical aptasensor based on gold nanoparticles dotted graphene modified glassy carbon electrode for label-free detection of bisphenol A in milk samples," Food Chemistry, vol. 162, pp. 34-40, 2014.

[236] K. V. Ragavan, L. S. Selvakumar, and M. S. Thakur, "Functionalized aptamers as nano-bioprobes for ultrasensitive detection of bisphenol-A," Chemical Communications, vol. 49, no. 53, pp. 5960-5962, 2013.

[237] Z. Mei, H. Chu, W. Chen et al., "Ultrasensitive one-step rapid visual detection of bisphenol A in water samples by label-free aptasensor," Biosensors and Bioelectronics, vol. 39, no. 1, pp. 2630, 2013.

[238] Z. Mei, W. Qu, Y. Deng et al., “One-step signal amplified lateral flow strip biosensor for ultrasensitive and on-site detection of bisphenol A (BPA) in aqueous samples," Biosensors and Bioelectronics, vol. 49, pp. 457-461, 2013.

[239] D. Yao, G. Wen, and Z. Jiang, "A highly sensitive and selective resonance Rayleigh scattering method for bisphenol A detection based on the aptamer-nanogold catalysis of the $\mathrm{HAuCl}_{4}-$ vitamin C particle reaction," RSC Advances, vol. 3, no. 32, pp. 13353-13356, 2013.

[240] J. Lee, M. Jo, T. H. Kim et al., "Aptamer sandwich-based carbon nanotube sensors for single-carbon-atomic-resolution detection of non-polar small molecular species," Lab on a Chip, vol. 11, no. 1, pp. 52-56, 2011.

[241] H. Kuang, H. Yin, L. Liu, L. Xu, W. Ma, and C. Xu, "Asymmetric plasmonic aptasensor for sensitive detection of bisphenol a," ACS Applied Materials \& Interfaces, vol. 6, no. 1, pp. 364-369, 2014.

[242] L. Fan, G. Zhao, H. Shi, M. Liu, Y. Wang, and H. Ke, "A femtomolar level and highly selective $17 \beta$-estradiol photoelectrochemical aptasensor applied in environmental water samples analysis," Environmental Science and Technology, vol. 48, no. 10, pp. 5754-5761, 2014.

[243] Z. Lin, L. Chen, G. Zhang et al., "Label-free aptamer-based electrochemical impedance biosensor for $17 \beta$-estradiol," Analyst, vol. 137, no. 4, pp. 819-822, 2012.

[244] N. Yildirim, F. Long, C. Gao, M. He, H.-C. Shi, and A. Z. $\mathrm{Gu}$, "Aptamer-based optical biosensor for rapid and sensitive detection of $17 \beta$-estradiol in water samples," Environmental Science and Technology, vol. 46, no. 6, pp. 3288-3294, 2012.

[245] H. Shi, G. Zhao, M. Liu, L. Fan, and T. Cao, "Aptamer-based colorimetric sensing of acetamiprid in soil samples: sensitivity, selectivity and mechanism," Journal of Hazardous Materials, vol. 260, pp. 754-761, 2013.

[246] L. Fan, G. Zhao, H. Shi, M. Liu, and Z. Li, "A highly selective electrochemical impedance spectroscopy-based aptasensor for sensitive detection of acetamiprid," Biosensors and Bioelectronics, vol. 43, no. 1, pp. 12-18, 2013.

[247] C. Zhang, L. Wang, Z. Tu et al., "Organophosphorus pesticides detection using broad-specific single-stranded DNA based fluorescence polarization aptamer assay," Biosensors and Bioelectronics, vol. 55, pp. 216-219, 2014.
[248] J. R. Deeds, J. H. Landsberg, S. M. Etheridge, G. C. Pitcher, and S. W. Longan, "Non-traditional vectors for paralytic shellfish poisoning," Marine Drugs, vol. 6, no. 2, pp. 308-348, 2008.

[249] S. L. Morton and D. R. Tindall, "Determination of okadaic acid content of dinoflagellate cells: a comparison of the HPLCfluorescent method and two monoclonal antibody ELISA test kits," Toxicon, vol. 34, no. 8, pp. 947-954, 1996.

[250] E. Petzinger and K. Ziegler, "Ochratoxin A from a toxicological perspective," Journal of Veterinary Pharmacology and Therapeutics, vol. 23, no. 2, pp. 91-98, 2000.

[251] N. W. Turner, S. Subrahmanyam, and S. A. Piletsky, "Analytical methods for determination of mycotoxins: a review," Analytica Chimica Acta, vol. 632, no. 2, pp. 168-180, 2009.

[252] G. Wood, Y. Lee, K. Egan, and M. Bolger, "US Food and Drug Administration's monitoring and surveillance programs for mycotoxins, pesticides and contaminants in food," Journal of Environmental Monitoring, vol. 3, no. 5, pp. 79N-83N, 2001.

[253] A. Zinedine, J. M. Soriano, J. C. Moltó, and J. Mañes, "Review on the toxicity, occurrence, metabolism, detoxification, regulations and intake of zearalenone: an oestrogenic mycotoxin," Food and Chemical Toxicology, vol. 45, no. 1, pp. 1-18, 2007.

[254] Y. Li, Z. Wang, R. C. Beier et al., “T-2 toxin, a trichothecene mycotoxin: review of toxicity, metabolism, and analytical methods," Journal of Agricultural and Food Chemistry, vol. 59, no. 8, pp. 3441-3453, 2011.

[255] J. W. Bennett and M. Klich, "Mycotoxins," Clinical Microbiology Reviews, vol. 16, no. 3, pp. 497-516, 2003.

[256] S. Tabata, H. Kamimura, A. Ibe et al., "Aflatoxin contamination in foods and foodstuffs in Tokyo: 1986-1990," Journal of AOAC International, vol. 76, no. 1, pp. 32-35, 1993.

[257] H. T. Hung, J. Höjer, T. X. Kiem, and N. T. Du, “A controlled clinical trial of a novel antivenom in patients envenomed by Bungarus multicinctus," Journal of Medical Toxicology, vol. 6, no. 4, pp. 393-397, 2010.

[258] S. Nirthanan and M. C. E. Gwee, "Three-finger $\alpha$-neurotoxins and the nicotinic acetylcholine receptor, forty years on," Journal of Pharmacological Sciences, vol. 94, no. 1, pp. 1-17, 2004.

[259] G. Schönfelder, W. Wittfoht, H. Hopp, C. E. Talsness, M. Paul, and I. Chahoud, "Parent bisphenol a accumulation in the human maternal-fetal-placental unit," Environmental Health Perspectives, vol. 110, no. 11, pp. A703-A707, 2002.

[260] K. Srogi, "Levels and congener distributions of PCDDs, PCDFs and dioxin-like PCBs in environmental and human samples: a review," Environmental Chemistry Letters, vol. 6, no. 1, pp. 1-28, 2008.

[261] M. Graymore, F. Stagnitti, and G. Allinson, "Impacts of atrazine in aquatic ecosystems," Environment International, vol. 26, no. 7-8, pp. 483-495, 2001.

[262] Y. Xiao, A. A. Lubin, A. J. Heeger, and K. W. Plaxco, "Labelfree electronic detection of thrombin in blood serum by using an aptamer-based sensor," Angewandte Chemie-International Edition, vol. 44, no. 34, pp. 5456-5459, 2005.

[263] C. Deng, J. Chen, Z. Nie et al., "Impedimetric aptasensor with femtomolar sensitivity based on the enlargement of surfacecharged gold nanoparticles," Analytical Chemistry, vol. 81, no. 2, pp. 739-745, 2009.

[264] L. Tan, K. G. Neoh, E.-T. Kang, W.-S. Choe, and X. Su, "Affinity analysis of DNA aptamer-peptide interactions using gold nanoparticles," Analytical Biochemistry, vol. 421, no. 2, pp. 725-731, 2012. 
[265] W. Wang, C. Chen, M. Qian, and X. S. Zhao, "Aptamer biosensor for protein detection using gold nanoparticles," Analytical Biochemistry, vol. 373, no. 2, pp. 213-219, 2008.

[266] L. Wang, X. Liu, X. Hu, S. Song, and C. Fan, "Unmodified gold nanoparticles as a colorimetric probe for potassium DNA aptamers," Chemical Communications, no. 36, pp. 3780-3782, 2006.

[267] J. Liu and Y. Lu, "Fast colorimetric sensing of adenosine and cocaine based on a general sensor design involving aptamers and nanoparticles," Angewandte Chemie, vol. 45, no. 1, pp. 9094, 2005.

[268] V. Pavlov, Y. Xiao, B. Shlyahovsky, and I. Willner, "Aptamerfunctionalized Au nanoparticles for the amplified optical detection of thrombin," Journal of the American Chemical Society, vol. 126, no. 38, pp. 11768-11769, 2004.

[269] M. D. Schlensog, T. M. A. Gronewold, M. Tewes, M. Famulok, and E. Quandt, "A Love-wave biosensor using nucleic acids as ligands," Sensors and Actuators B: Chemical, vol. 101, no. 3, pp. 308-315, 2004.

[270] K. S. Hwang, S.-M. Lee, K. Eom et al., "Nanomechanical microcantilever operated in vibration modes with use of RNA aptamer as receptor molecules for label-free detection of HCV helicase," Biosensors and Bioelectronics, vol. 23, no. 4, pp. 459465, 2007.

[271] R. E. Wang, H. Wu, Y. Niu, and J. Cai, "Improving the stability of aptamers by chemical modification," Current Medicinal Chemistry, vol. 18, no. 27, pp. 4126-4138, 2011. 

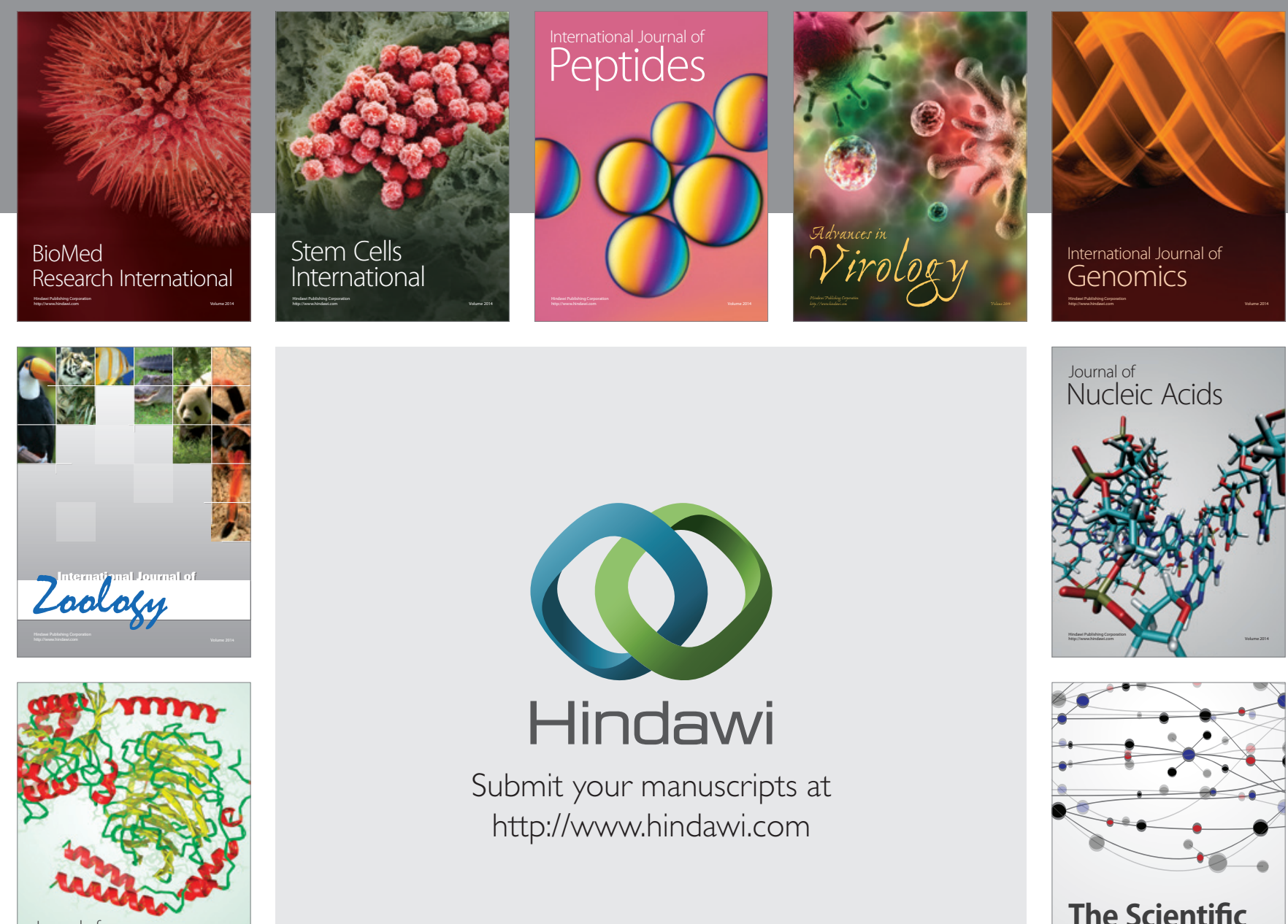

Submit your manuscripts at

http://www.hindawi.com

Journal of
Signal Transduction
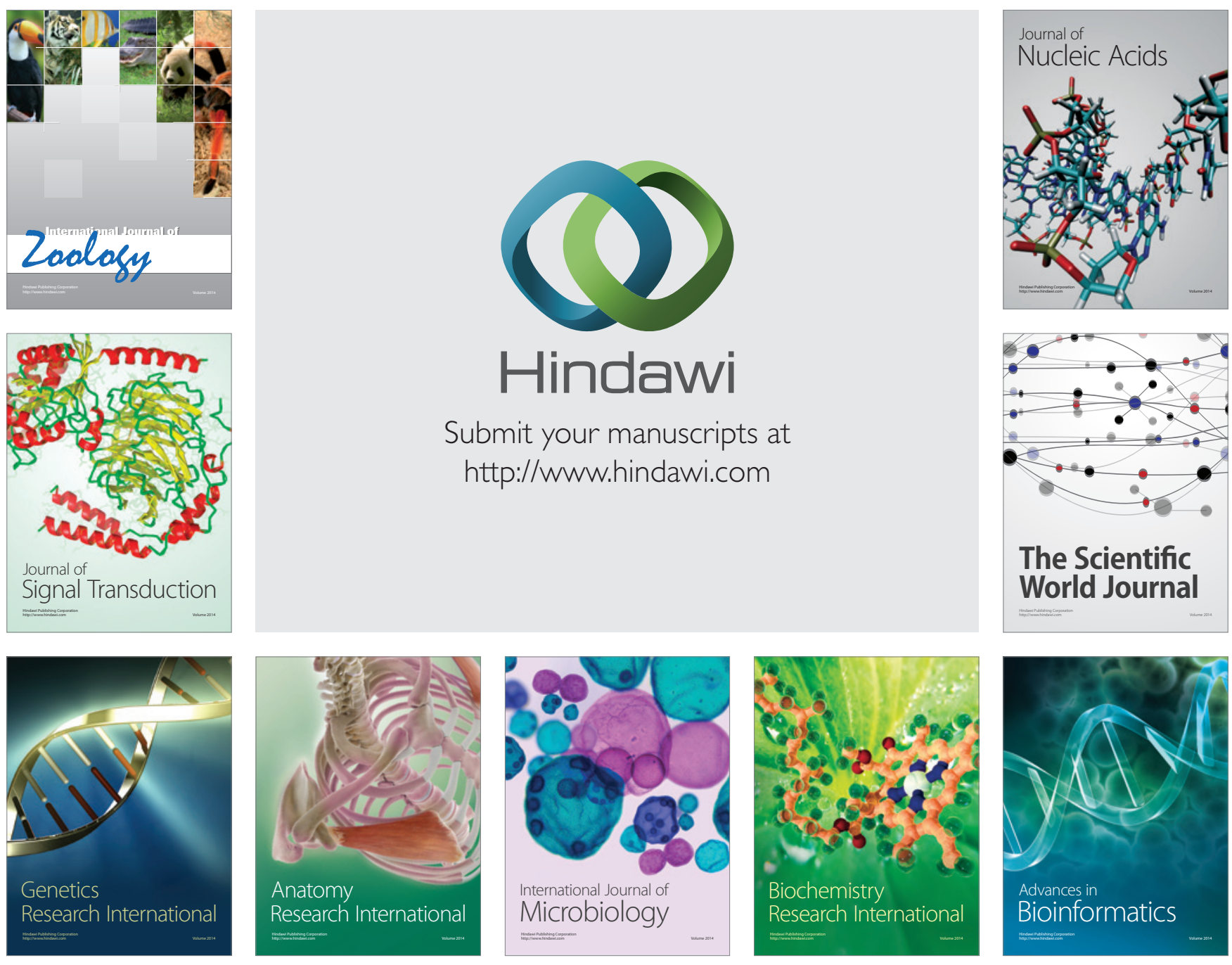

The Scientific World Journal
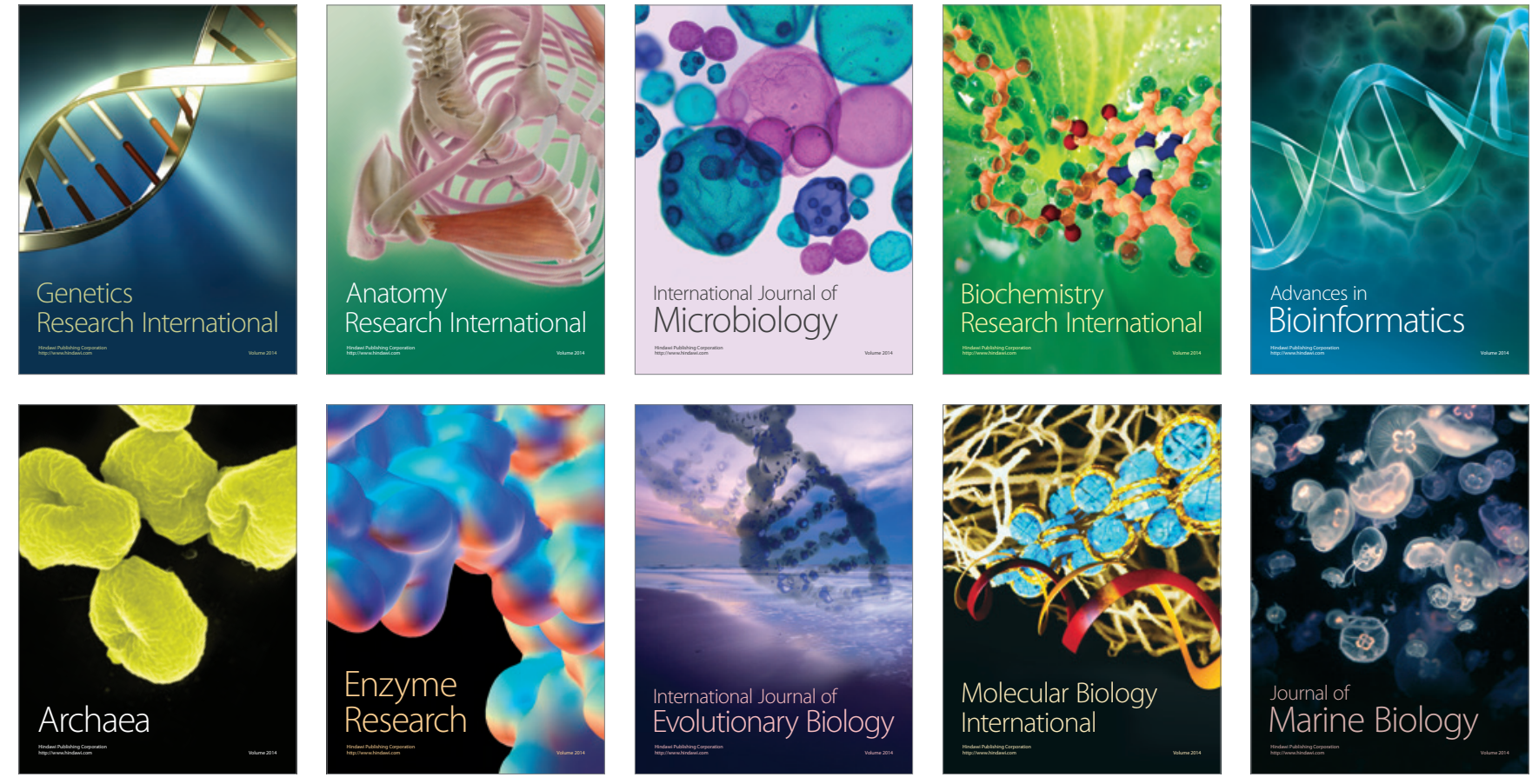